\title{
AVALIAÇÃO DA RESISTÊNCIA COESIVA E DA MICRODUREZA DE UMA RESINA COMPOSTA POLIMERIZADA COM FONTES DE LUZ HALÓGENA E LED.
}

\section{PATRÍCIA ALEIXO DOS SANTOS}

Dissertaçāo apresentada à Faculdade de Odontologia de Bauru, da Universidade de São Paulo, com parte dos requisitos para a obtenção do título de Mestre em Odontologia, área de Dentistica.

(Edição Revisada) 
Filiação

Nascimento

Naturalidade

1998 a 2001

2001

Associações
Odimar Achilles Soares dos Santos

Ana Maria Aleixo dos Santos

26 de janeiro de 1979

Curso de Odontologia na Faculdade de Odontologia de Araraquara - Universidade Estadual Paulista, Araraquara SP.

Curso de Aperfeiçoamento em Dentística Estética e Cosmética, na Associação Paulista de Cirurgiões-Dentistas (regional de Araraquara) - SP

APCD - Associação Paulista de Cirurgiões-Dentistas (regional de Araraquara) - SP

GBPD - Grupo Brasileiro de Professores de Dentística SBPqO - Sociedade Brasileira de Pesquisa Odontológica 
"O mais importante da vida não é a situação em que estamos, mas a direção para a qual nos movemos."

(Oliver Wendell Holmes) 
Agradeço aos meus queridos pais, Odimar e Ana Maria, pela constante dedicação, apoio e amor incondicional, sempre depositando em mim a confiança e o incentivo para realizar este trabalho, acreditando em minha capacidade de alcançar meus objetivos. Vocês são as pessoas mais importantes da minha vida. A vocês, dedico toda minha gratidão, respeito e amor.

A Deus, por sempre abençoar a mim e minha família, proporcionando-me perseverança e força suficientes para superar todas as dificuldades que pudessem me fazer desistir. Sua presença me faz, a cada instante, acreditar mais na beleza da vida e na intensidade em que devem ser aproveitados todos os momentos bons e ruins, pois foi dentre erros e acertos, que sempre me acolheu. 
À minha irmã, Daniella, pelo incentivo e por ser um exemplo de garra e inclinação pelo trabalho, o que muitas vezes foi a energia que me motivou a nunca desistir de lutar. Peço perdão pela minha ausência em muitos momentos, embora saiba que sua compreensão é maior que qualquer distância que possamos nos encontrar.

Aos meus amigos, Jonas, Emi, Vivian, Fernanda, que mesmo à distância, continuaram a partilhar sua amizade comigo. Sou eternamente grata a estas pessoas que fazem parte da minha vida e fazem dos meus dias mais alegres e completos.

À especial amiga de república, Patrícia, que acompanhou de perto toda esta trajetória. Obrigada pela paciência, companheirismo e principalmente, por todo tempo que passamos juntas nestes dois anos.

À amiga Luciana, que também participou de perto desta caminhada e pôde observar a dedicação com que este trabalho foi realizado. Obrigada pela amizade sincera! 


\section{Agradecimento Especial}

Ao meu orientador Prof. Dr. Eduardo Batista Franco, pela orientação e confiança prestadas. Por sua seriedade frente ao exercício do ensino, por externar todo seu conhecimento e sabedoria humildemente, demonstrando seu entusiasmo na carreira docente, o que para mim será sempre um exemplo a ser seguido. Agradeço também pela amizade estabelecida durante este período do curso e por todo apoio depositado em meus projetos.

“Aprender é a única coisa de que a mente nunca se cansa, nunca tem medo e nunca se arrepende."

(Leonardo da Vinci) 
Ao Prof. Dr. José Mondelli, pelo exemplo de profissionalismo transmitido aliado à paixão pela carreira docente. Agradeço a amizade que será sempre lembrada por quem o admira como ser humano e o profissional que representa no âmbito da Odontologia.

Ao Prof. Dr. Rafael Francisco Lia Mondelli, por toda atenção, pela maneira educada e prestativa com que sempre me tratou, permitindo o uso do aparelho fotoativador Ultrablue IS (DMC) para a realização deste trabalho.

À Profa. Dra. Maria Fidela de Lima Navarro, pelas oportunidades proporcionadas aos alunos de pós-graduação desta faculdade, sempre transmitindo entusiasmo e coragem para dirigir uma escola renomada e reconhecida como a Faculdade de Odontologia de Bauru.

A todos os professores da área de Dentística, Doutores Aquira Ishikiriama; Carlos Eduardo Francischone; Eduardo Batista Franco; José Carlos Pereira; José Mondelli; Maria Fidela de Lima Navarro; Maria Teresa Atta A. Bastos; Rafael Francisco Lia Mondelli e Ricardo Marins de Carvalho, pela oportunidade de aprender o que é ser um verdadeiro educador. 
Aos funcionários do Departamento de Dentística, Endodontia e Materiais Dentários, Nelson, Sr. Dito, Júnior, Karen, Rita, Ângela, Elisabeth, Zuleica, Zilei, Sandrinha e Alcides, pelo carinho e educação com que me trataram durante este.

Aos funcionários da seção de Pós-Graduação, Giane, Letícia, Margareth, pela paciência e solicitude com que sempre me receberam, além da amizade que pudemos estabelecer.

Aos funcionários da Clínica de Pós-Graduação, Cleusinha e Eduardo, por permitir condições adequadas para que os trabalhos fossem realizados com qualidade.

Aos funcionários do Serviço de Biblioteca da FOB-USP, pela simpatia, paciência em orientar nos levantamentos bibliográficos e pela eficiência em seu trabalho.

Em especial, ao Reivanildo por todo apoio prestado na utilização das dependências do laboratório de pesquisa do Departamento de Prótese, assim como por seu empenho em auxiliar na realização dos experimentos desta pesquisa. 
Aos colegas de turma de mestrado André, Adilson, Ana Carolina, Adriana, Débora, Juliana, Maria Cecília, Mónica, Miguel, Safira e Ticiane, pelo convívio durante o curso, pela amizade e mútua colaboração na conquista deste trabalho. Em especial, gostaria de agradecer ter conhecido pessoas como o André, Maria Cecília, Mónica e Ticiane por serem tão verdadeiras e demonstrarem carinho e afeição à minha pessoa. Saibam que vocês estarão sempre em meu coração!

Aos colegas de pós-graduação, Anuradha, Ana Raquel, Angélica, Eduardo, Fabiano, Flávia, Leonardo, Luiz, Margareth, Terezinha, Renato e Serginho, por sua disposição em estar sempre ajudando de alguma forma aqueles que estavam ainda iniciando seu caminho pela pós-graduação.

Ao CNPq pelo apoio financeiro prestado durante a realização deste curso de Mestrado. 


\section{Dedico ainda este trabalho...}

À professora Patrícia Petromilli Nordi Sasso Garcia, responsável pela minha escolha em seguir a carreira acadêmica, tamanho seu entusiasmo e motivação que demonstrou durante o período em que me orientou na graduação. Admiradora de seu exemplo de disciplina, integridade e organização, qualidades estas unidas à humildade, ternura e coragem, posso dizer que, além de minha orientadora, sempre será considerada minha grande amiga. A você minha eterna gratidão! 


\section{SUMÁRIO}

LISTA DE ABREVIATURAS, SIGLAS E SÍMBOLOS...............................iv

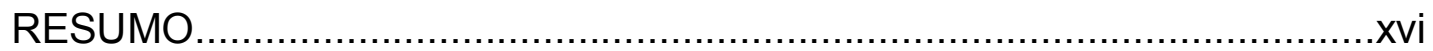

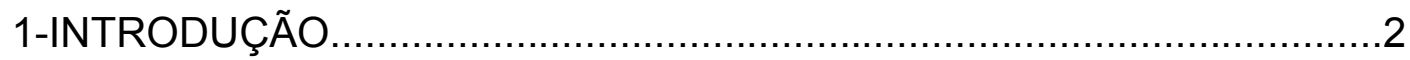

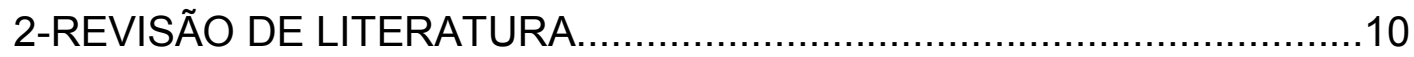

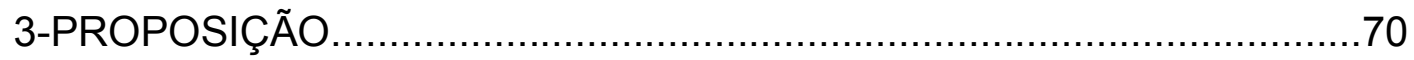

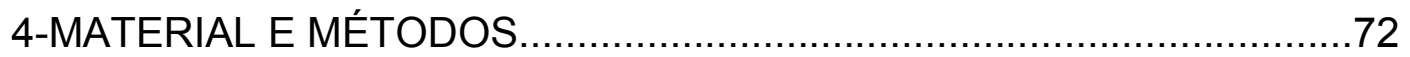

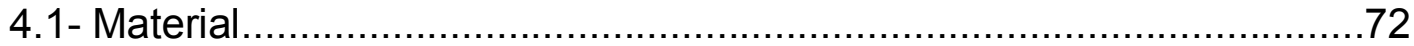

4.2-Preparo dos espécimes para testes de resistência à tração...............75

4.3 -Testes de resistência à tração..................................................79

4.4 -Preparo dos espécimes para testes de microdureza.......................81

4.5 -Testes de microdureza.............................................................. 82



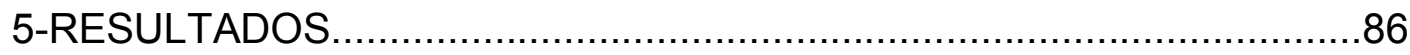

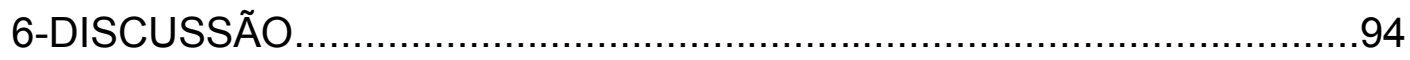

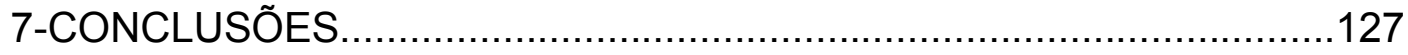

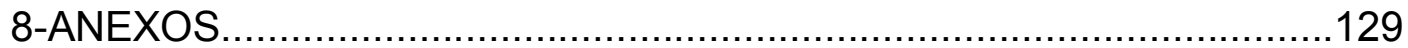

9-REFERÊNCIAS BIBLIOGRÁFICAS..............................................143

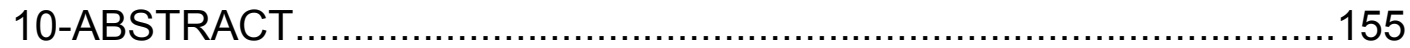




\section{LISTA DE ABREVIATURAS, SIGLAS E SÍMBOLOS}

$\begin{array}{ll}\text { LED } & \text { Light Emitting Diode } \\ \text { InGaN } & \text { indio-gálio-nitrogênio } \\ \mathrm{CQ} & \text { Canforoquinona } \\ \mathrm{ISO} & \text { International Standard Organization } \\ \mathrm{mW} / \mathrm{cm}^{2} & \text { miliwatts por centímetro quadrado } \\ \mathrm{KHN} & \text { Knoop Hardness Number } \\ \mathrm{Kgf} / \mathrm{cm}^{2} & \text { Quilograma-força por centímetro quadrado } \\ \mathrm{MPa} & \text { Mega Pascal } \\ \mathrm{mm} & \text { Milímetro } \\ \mathrm{cm} & \text { Centímetro } \\ \mathrm{nm} & \text { Nanômetro } \\ \mathrm{Hz} & \text { Hertz } \\ \mathrm{W} & \text { Watts } \\ \mathrm{mm} / \mathrm{min} & \text { Milímetros por minuto } \\ \mathrm{g} & \text { Gramas } \\ \mathrm{s} & \text { Segundos } \\ \mathrm{CL} & \text { Curing Light } 2500 \\ \mathrm{UTL} & \text { Ultraled } \\ \mathrm{UB} 3 & \text { Ultrablue }-300 \mathrm{~mW} / \mathrm{cm}^{2} \\ \mathrm{UB} 6 & \text { Ultrablue }-600 \mathrm{~mW} / \mathrm{cm}^{2} \\ \varnothing & \text { Diâmetro } \\ & \end{array}$


Resumo 


\section{RESUMO}

O presente estudo teve como objetivo avaliar a resistência coesiva, por meio do teste de tração, de uma resina composta fotopolimerizável (Z250 3M/ESPE) com variação de espessura do material, utilizando aparelhos de lâmpada halógena (Curing Light 2500 - 3M/ESPE - CL) e do tipo LED (Ultraled - Dabi-Atlante - UTL e UltraBLue - DMC - UB3 e UB6) com diferentes densidades de potência $\left(130 \mathrm{~mW} / \mathrm{cm}^{2}, 300 \mathrm{~mW} / \mathrm{cm}^{2}\right.$ e $\left.600 \mathrm{~mW} / \mathrm{cm}^{2}\right)$, assim como a influência do tempo de ativação (20s, 40 s e 60 s) e, adicionalmente, relacionar essa resistência com a microdureza na porção correspondente à região de fratura do material. Foram estabelecidos 24 grupos $(n=10)$, sendo utilizadas duas matrizes de aço segmentadas, com espessuras de 1 e $2 \mathrm{~mm}$ para a obtenção dos espécimes. Posteriormente, os corpos-de-prova foram submetidos ao teste de tração na Máquina Universal de Ensaios Kratos, utilizando-se a célula de carga de $50 \mathrm{~g}$ e velocidade de $0,5 \mathrm{~mm} / \mathrm{min}$. Os valores de resistência à tração foram obtidos em $\mathrm{kgf} / \mathrm{cm}^{2}$ e transformados em MPa. Para o teste de microdureza, as mesmas matrizes foram utilizadas para confecção dos espécimes (24 grupos com n=5), analisando-se a dureza na interface correspondente à área de união. $\mathrm{O}$ teste de microdureza Knoop foi realizado com auxílio do Microdurômetro Shimadzu HMV-2, com carga estática de $50 \mathrm{~g}$ por $30 \mathrm{~s}$. Os valores obtidos foram submetidos à análise de variância (ANOVA) e, para as comparações individuais, foi realizado o teste de Tukey $(p<0,05)$. Os resultados permitiram observar, no que se refere ao desempenho individual dos aparelhos avaliados, que houve similaridade na 
resistência à tração para os diferentes tempos empregados (20s, 40s e 60s), tanto para espessura de $1 \mathrm{~mm}$ como de $2 \mathrm{~mm}$; a resistência à tração da resina composta mostrou-se superior para espessura de $2 \mathrm{~mm}$, enquanto que a microdureza, na área correspondente à interface de união, apresentou valores maiores para a espessura de $1 \mathrm{~mm}$, demonstrando que uma maior microdureza não implica, por si só, em resistência à tração superior; com relação à microdureza do material, a lâmpada halógena alcançou resultados superiores às fontes de LED; a variação da espessura do material e do tempo de exposição não influenciou na microdureza da interface de união para os diferentes aparelhos, mas evidenciou que aparelhos de menor densidade de potência necessitam de maior tempo de ativação para se equipararem às fontes com maior densidade de potência. 
1. INTRODUÇÃO 


\section{1 - INTRODUÇÃO}

A busca incessante por um material ideal para substituir a perda da estrutura dentária tem sido uma constante na Odontologia. Nesse sentido, os materiais restauradores vêm sendo desenvolvidos com o intuito de alcançar propriedades físicas e mecânicas que sejam similares às encontradas no substrato dentário.

As propriedades das resinas compostas têm sido reavaliadas com freqüência, assim como os fatores que podem influenciá-las. Sabe-se que o grau de polimerização pode alterar algumas de suas propriedades, tais como dureza e resistência intrínseca do material, dependendo de fatores como: cor da resina, tempo de polimerização, tipo de aparelho fotopolimerizador, densidade de potência, espectro da luz emitida e espessura do incremento. ${ }^{12,18,34,43,51,64,67,75}$ Devido a esses fatores, parte do material pode não ser adequadamente polimerizada e isso pode aumentar a absorção de água e a solubilidade do material, afetando a estética da restauração. ${ }^{18} \mathrm{Em}$ regiões do material onde a cura não é efetiva, o resultado clínico pode culminar em sensibilidade pósoperatória, infiltração marginal e fracasso da restauração. ${ }^{15,46}$

Para a polimerização das resinas atuais, o processo se inicia através da absorção da luz visível pela molécula fotoiniciadora que, na maior parte das resinas compostas, é a canforoquinona. Tal molécula é excitada por comprimento de onda adequado $(468 \mathrm{~nm})^{9,45}$, quando se inicia um processo de geração de radicais livres, os quais, por sua vez, causam o desenvolvimento de cadeias poliméricas. A luz penetra na parte superficial da resina, mas a absorção no 
material impede que a luz alcance as partes mais profundas. Os radicais livres da superfície iniciam a polimerização, porém esta não se propaga em profundidade além de certo limite. Portanto, as porções mais profundas da resina podem permanecer não polimerizadas, caso a mesma seja aplicada com espessura além da aceitável clinicamente. ${ }^{32}$ Faz-se necessário que adequado comprimento de onda e densidade de potência sejam alcançados em toda região da restauração para se estabelecer o máximo de polimerização e sucesso clínico a longo prazo. $^{18,67}$

A polimerização adequada das resinas compostas é condição determinante para se obter o melhor desempenho do material em suas propriedades físicomecânicas. ${ }^{45}$ A contração gerada durante o processo de polimerização se exacerba quando a velocidade de cura do material é acelerada, sendo que o grau de conversão dos monômeros em polímeros diminui quanto mais espesso for o incremento. No caso de se utilizar uma técnica de polimerização lenta, acredita-se que o desenvolvimento do estresse de contração de polimerização possa ser aliviado pelo escoamento da resina composta, prolongando-se a fase "pré-gel", quando o material ainda não se apresenta completamente rígido. ${ }^{9,62}$ Uma vez atingido o "ponto gel", o material não cede muito elasticamente, pois o polímero atinge seu módulo de elasticidade mais alto (maior rigidez), o que transfere o estresse de polimerização para as interfaces da restauração, podendo ocasionar a desadaptação ou fenda marginal. ${ }^{55}$

Por muitos anos, os aparelhos de lâmpada halógena têm sido empregados como um equipamento útil de polimerização das resinas. Para a emissão da luz, 
dentro do espectro azul, com potência média de saída em torno de 200 a $400 \mathrm{~mW} / \mathrm{cm}^{2}$, as unidades operam com um bulbo que emite luz branca e passa por um filtro dielétrico para eliminar comprimentos de onda indesejáveis. ${ }^{38}$ Esse processo de obtenção de luz azul, pelos dispositivos convencionais, exibe perda demasiada de energia dissipada na forma de calor, além do feixe carregar uma grande quantidade de luz fora da região espectral de interesse para a polimerização. $^{33}$

O uso das unidades de lâmpada halógena, embora bastante difundido entre os profissionais, apresenta algumas desvantagens como: degradação da lâmpada, refletor, filtro e fibra óptica devido às altas temperaturas produzidas, gerando modificações no espectro de emissão de luz e diminuição de potência de saída com o tempo de uso. Isso, conseqüentemente, ocasiona a diminuição na efetividade de polimerização com o uso do aparelho. ${ }^{6,33,35,72}$

O tempo de vida da lâmpada halógena é relativamente curto, cerca de 100 horas, necessitando de reposição com regularidade para que seja evitada uma perda de potência do aparelho fotopolimerizador. ${ }^{6,12}$ Entretanto, a correta manutenção não costuma ser dada a esse componente do aparelho, assim como a troca do filtro, que deveria ocorrer de tempo em tempo. Tais aspectos são muito pouco lembrados pelos profissionais em seus consultórios e nas faculdades de Odontologia, acarretando conseqüências negativas na qualidade dos procedimentos restauradores dependentes do processo de polimerização. Com a densidade de potência diminuída, a polimerização pode se apresentar incompleta 
e, desse modo, ter suas propriedades mecânicas afetadas, como a diminuição da resistência do material. ${ }^{43}$

Atualmente, existe uma variedade de técnicas fotopolimerizadoras e cada técnica tem suas vantagens e desvantagens com respeito às propriedades da restauração final e ao comportamento do elemento dentário a longo prazo. ${ }^{75}$

Com o intuito de substituir a lâmpada halógena, o laser de argônio e o arco de plasma foram muito estudados, na tentativa de otimizar a fotopolimerização. No entanto, algumas desvantagens têm sido relatadas na literatura ${ }^{48}$ tornando, muitas vezes, inviável seu o uso em consultórios.

Uma fonte de luz fotopolimerizadora recentemente disponibilizada para a Odontologia refere-se ao LED. As unidades de LED surgiram de uma base sólida de tecnologia e de um considerável número de estudos inicialmente estabelecidos, que deram suporte para que fossem usadas na polimerização dos compósitos. Tais descobertas permitiram aos pesquisadores a curiosidade de explorar o uso do LED devido às suas possíveis vantagens sobre as tecnologias anteriores. $^{19}$

O LED (Light Emitting Diode) é um diodo composto por um semicondutor de InGaN (índio - gálio - nitrogênio). Apresenta uma junção do tipo n-p, onde um lado é doador de elétrons e o outro é receptor de elétrons. Quando a tensão aplicada transpõe uma barreira de energia chamada GAP, ocorre a passagem de elétrons da camada de valência para a de condução, gerando um fluxo de elétrons. Na junção n-p ocorre emissão de fótons, gerando luz. ${ }^{31,35}$ 
Os aparelhos de LEDs azuis, em geral, apresentam o espectro de emissão em banda estreita entre 450-490nm, com pico de emissão de comprimento de onda de aproximadamente $470 \mathrm{~nm} \cdot{ }^{37,48}$ Nessa região do espectro está contido o pico de absorção do fotoiniciador das resinas compostas dentais, a canforoquinona, não sendo requerido, portanto, o uso de filtros. Essa pureza espectral permite um aproveitamento total da luz emitida, o que resulta em mínima geração de calor, diferentemente do ocorrido com o aparelho de lâmpada halógena. ${ }^{38,51,79}$ Ocorre, também, que a maior proporção de energia coincidente com o pico de absorção da canforoquinona faz com que o fluxo de energia liberado apresente-se melhor para a conversão dos monômeros da resina composta.

O principal problema evidenciado inicialmente pelos aparelhos de LED foi a reduzida potência, o que traria, como conseqüência, uma incompleta polimerização do material restaurador, pois uma pequena mudança na densidade de potência causaria uma significante alteração no grau de conversão na zona superficial da resina composta. ${ }^{50}$ Por outro lado, alguns estudos ${ }^{3,15}$ evidenciam que esses aparelhos são capazes de proporcionar uma polimerização adequada da resina composta, da mesma maneira como é conseguido com aparelhos de lâmpada halógena em boas condições de utilização. Não obstante, diferentes trabalhos apresentados na literatura ${ }^{39,69,76}$ mostram que existem algumas diferenças quanto à efetividade dos aparelhos do tipo LED, em comparação com as fontes de luz de lâmpada halógena. 
Alguns autores, como JANDT et al. (2000) ${ }^{35}$ e MILLS;JANDT; ASHWORTH $(1999)^{48}$, mostraram na literatura que o LED azul tem um potencial de polimerizar as resinas compostas dentro dos padrões estabelecidos pela ISO, quanto à profundidade de polimerização e a resistência à tração. No entanto, durante seus estudos, ainda não estavam disponíveis no mercado as novas versões dos LEDs como unidades fotopolimerizadoras, sendo realizados os estudos com modelos experimentais.

Os LEDs de $1^{\text {a }}$ geração apresentavam um, relativamente, baixo potencial de irradiação comparado aos aparelhos de lâmpada halógena, embora sua composição de múltiplos diodos dispostos em arranjo pudessem, de acordo com alguns autores ${ }^{35,65}$, alcançar os mesmos valores de energia dos aparelhos convencionais. No entanto, unidades de diodo de alta potência foram utilizadas na tecnologia dos aparelhos de $2^{a}$ geração, permitindo que estes oferecessem uma densidade de potência maior que os anteriores.

Com o lançamento de aparelhos de LED com maior densidade de potência, há necessidade de se investigar seu potencial de polimerização, no que diz respeito à variação de espessura do material restaurador (resina composta) e da diversificação do tempo de ativação, de forma que se permita correlacionar com o grau de cura observado frente às condições experimentais propostas. Face ao entendimento de que o teste de dureza superficial de uma restauração polimerizada, isoladamente, não é um guia adequado para avaliar o grau de polimerização do material, haja vista que a superfície do mesmo irá polimerizar invariavelmente, mesmo com uma unidade fotopolimerizadora de baixa potência, 
outros testes mecânicos devem ser associados ao de microdureza para analisar as propriedades físicas do material restaurador após serem polimerizados com esses equipamentos. ${ }^{18}$

Tendo por base o pressuposto anteriormente referido, o objetivo do presente trabalho foi avaliar a influência da ativação de diferentes fontes de luz à base de LED, comparativamente à lâmpada halógena, sobre a resistência coesiva de espécimes de resina composta, assim como a análise da microdureza na interface correspondente à área de união do material. 
2. REVISÃo dE LITERATURA 


\section{2 - ReVisão de Literatura}

YEARN; MACCLESFIELD ${ }^{81}$, em 1985, publicaram uma revisão sobre os principais fatores que determinam as características de cura e, conseqüentemente, da performance das resinas fotopolimerizáveis. Percebeu-se que, dentre os fatores que afetam a polimerização, a composição química das resinas é importante na determinação da proporção em que se procederá a polimerização. Estas diferenças na composição química podem ser com relação ao monômero envolvido (Bis-GMA ou dimetacrilato de uretano,) ou a diferentes combinações de catalisadores diquetona/amina. Materiais com a mesma composição (resinosa e de partículas), porém com diferentes combinações de catalisadores, variaram na profundidade de polimerização (para catalisador A, $1 \mathrm{~mm}$ de profundidade de cura e para $B, 2-3 \mathrm{~mm})$. As principais variáveis na composição que determinam o grau de polimerização, em qualquer camada do compósito, são aquelas que influenciam a habilidade da luz de atingir a respectiva camada. São fatores que facilitam ou impedem a transmissão da luz. Enquanto alguma luz é absorvida pelo próprio catalisador, os principais fatores inibidores são as propriedades ópticas da mistura resina/partículas. Mesmo usando-se a mesma combinação resina/partículas, a diferença na transmissão pode ocorrer se os tamanhos das partículas forem diferentes, porque isto pode influenciar a dispersão da luz. Para qualquer formulação de resina, as características de cura são governadas pela quantidade e qualidade da luz proveniente da fonte de radiação empregada, sendo esta igualmente dependente do operador, o qual controla o tempo de ativação e a distância da ponta ativa. Ao relacionar o 
comprimento de onda da luz incidida ao perfil de dureza, a faixa de $476,5 \mathrm{~nm}$ foi mais efetiva. Na extensão além de 500nm o benefício é mínimo e há produção de calor, o que pode adversamente afetar a polpa e os tecidos moles. Do mesmo modo, comprimentos de onda na região ultravioleta, abaixo de 400nm, também contribuem pouco e devem preferivelmente ser eliminados.

FERRACANE et al. $^{21}$, em 1986, determinaram a profundidade de polimerização de resinas compostas fotopolimerizáveis por luz visível através de teste de dureza Knoop e de análise de espectroscopia infravermelha. Resinas compostas (Prisma Fine, Prisma Fil e Aurafill) de diferentes composições e cores foram utilizadas na confecção de corpos-de-prova com $5 \mathrm{~mm}$ de espessura, os quais foram expostos à luz durante 40 segundos, à distância de $2 \mathrm{~mm}$ da superfície do material. Após o armazenamento durante 24 horas, à temperatura de $37^{\circ} \mathrm{C}$, os espécimes foram submetidos ao teste de dureza Knoop com impressões realizadas a cada milímetro do material polimerizado, até a profundidade máxima de $4 \mathrm{~mm}$. O grau de conversão foi avaliado por meio da análise de espectroscopia, em corpos-de-prova confeccionados com matrizes metálicas de $4 \mathrm{~mm}$ de diâmetro e $3 \mathrm{~mm}$ de espessura. A partir dos resultados obtidos, os autores concluíram que as resinas compostas de cores claras (L) apresentaram maior profundidade de polimerização do que as de cores escuras (Y, G, GB). Entretanto, a cor mais escura da resina composta Aurafill (GB) apresentou resultado equivalente ao obtido com a cor mais clara (L) do mesmo material. Os autores relataram ainda que a profundidade de polimerização pode 
ser menos dependente da cor da resina composta do que de outros fatores, como por exemplo, a capacidade de transmissão da luz através do volume do material.

McCABE; CARRICK ${ }^{44}$, em 1989, desenvolveram um método para monitorar a intensidade da radiação de oito unidades fotopolimerizadoras por meio do uso de uma fotocélula condutiva de sulfato de cádmio, cuja resistência elétrica varia conforme a quantidade de luz que incide sobre a mesma. Filtros de seleção de comprimento de onda de banda extensa permitiram medir a densidade de potência e filtros de banda estreita permitiram medir a intensidade em 460 a 480nm. A profundidade de polimerização de quatro resinas compostas foi avaliada nas diferentes condições de luz. As unidades de luz, com maior densidade a $470 \mathrm{~nm}$, geralmente produziram maior profundidade de cura, sendo que esta era inversamente proporcional à atenuação da luz nesta faixa de emissão. Os resultados indicaram que ambos, densidade de potência da fonte e poder de atenuação do material, influenciaram na profundidade de cura.

Em 1990, ATMADJA; BRYANT ${ }^{4}$, examinaram alguns fatores que pudessem influenciar na profundidade de polimerização de quatro resinas compostas, P30 (3M), Prisma-Fil (Dentsply), Heliomolar Radiopaque (Vivadent) e Durafill (Kulzer), ativadas por luz visível (Heliomat/Vivadent) por meio da medição da dureza Knoop, em superfícies de 1, 2, 3, 4, e 6mm. Os resultados mostraram que em todas as profundidades (espessura de resina), a P30 apresentou maiores valores de dureza que Prisma-Fil que, por conseguinte, foram mais duras que as 
duas outras resinas microparticuladas. Cada material mostrou uma diminuição na dureza com o aumento da profundidade. Quantidades crescentes de micropartículas aumentam a quantidade de luz dissipada e diminui a profundidade de cura. Observaram que tempo de exposição maior geralmente resulta em maior dureza, havendo evidências que suportam o uso rotineiro de 40 s do que 20 s; porém, melhor seria utilizar incrementos mais finos de resina do que aumentar o tempo de exposição para otimizar a polimerização. A dureza aumentou aproximadamente $30 \%$ a partir dos 5 minutos até as 24 horas ou uma semana, indicando que as reações de ligações cruzadas continuam mesmo depois de removida a fonte de luz.

PILO; CARDASH ${ }^{57}$, em 1992, desenvolveram uma pesquisa para avaliar a microdureza Knoop no topo e na base de incrementos de resina composta de $2 \mathrm{~mm}$ de espessura, sendo os compósitos indicados tanto para restauração de dentes anteriores quanto para posteriores. As variáveis desta pesquisa incluíam tanto diferentes tempos de ativação (20s, 40s e 60s) do material como uma série de intervalos de tempo para medir a microdureza, desde imediatamente após a irradiação até passarem 72 horas do processo de cura. Os resultados mostraram que a dureza pós-irradiação tanto no topo como na base da resina aumentaram rapidamente na primeira hora após a polimerização, diminuindo sua velocidade durante as 24 horas seguintes e mantendo-se estável após este período. O aumento do tempo de exposição resultou em maiores valores de microdureza para ambas regiões. Tempos de ativação superiores àqueles recomendados 
pelos fabricantes foram necessários, especialmente para as resinas de micropartículas indicadas para restaurações anteriores, para alcançar os valores ótimos de dureza na base que deveriam ser $80-90 \%$ do máximo atingido na superfície do material (topo). O emprego de tempo mais prolongado de ativação é sugerido pelos autores para garantir que a restauração não tenha prejuízos nas suas propriedades mecânicas e nem esteja mais susceptível a manchamento e cárie recorrente.

Um estudo para avaliar o efeito da redução da densidade de potência das fontes de luz fotopolimerizadoras na profundidade de cura de vários compósitos e determinar a dureza destes materiais foi realizado por FOWLER; SWARTZ; MOORE ${ }^{23}$, em 1994. Além disso, os autores procuraram detectar a capacidade dos profissionais em consultório de perceber a redução da eficiência de seus aparelhos após determinado tempo de uso, testando a dureza do material polimerizado por meio de uma sonda exploradora nas superfícies de topo e base de um espécime. Para isto, foram utilizadas as resinas compostas APH, Occlusin, Prisma-Fill e Silux-Plus para confeccionar espécimes de 3mm de espessura que foram fotoativados com o aparelho de lâmpada halógena Coe Lite 4000 pelos tempos de exposição de 30s e 60s. Posteriormente, os espécimes foram submetidos ao teste de dureza Barcol e avaliados por clínicos com o auxílio de um explorador para o teste táctil, sendo que a dureza observada na superfície de topo era adotada como controle e a dureza na base comparada àquela. Os resultados encontrados indicaram que a dureza na base dos espécimes era 
menor devido à densidade de potência do aparelho sofrer um efeito da profundidade de cura do compósito, principalmente quando menor tempo de ativação foi empregado. Frente aos achados, os autores concluíram que o teste táctil é um método pouco confiável na análise da dureza e eficiência de polimerização e que o maior tempo de exposição do material à fonte de luz pode compensar alguma redução na sua densidade de potência, não deixando afetar o grau de polimerização desejado.

Em 1994, RUEGGEBERG; CAUGHMAN; CURTIS JUNIOR ${ }^{65}$, investigaram a interdependência do tempo de exposição e da densidade de potência na polimerização de resinas compostas, utilizando várias espessuras de material para simular o que ocorreria em uma restauração estética direta. Para isto, foram obtidos espécimes das resinas compostas P50 e Silux Plus (3M/ESPE), que foram fotoativados com a unidade de lâmpada halógena Demetron 401 (Demetron) pelos tempos de irradiância de 20, 40, 60 e 80 segundos. Para cada um destes tempos de exposição adotados, as densidades de potência foram sendo reduzidas com o uso de filtros, passando da densidade de $800 \mathrm{~mW} / \mathrm{cm}^{2}$, para $578 \mathrm{~mW} / \mathrm{cm}^{2}, 400 \mathrm{~mW} / \mathrm{cm}^{2}$ e $233 \mathrm{~mW} / \mathrm{cm}^{2}$, alterando, desta forma, a densidade de energia fornecida para a polimerização do material. Em seguida, os espécimes foram cortados para se obter fatias nas espessuras correspondentes a $1 \mathrm{~mm}, 2 \mathrm{~mm}$ e $3 \mathrm{~mm}$ da amostra original, permitindo que a resina pudesse ser avaliada também em profundidade. Posteriormente, a armazenagem da amostra ocorreu por 24 horas em ambiente escuro e então, os espécimes foram 
analisados quando ao seu grau de conversão por espectroscopia de infravermelho (FTIR). Os resultados foram expressivos no que se refere ao efeito da profundidade de polimerização na cura da resina composta. Em espessuras maiores que $2 \mathrm{~mm}$, os valores de conversão foram bastante inferiores aos demais e a polimerização nestes casos ficou mais susceptível a variações de densidade de potência e tempo de ativação. Os autores sugeriram, de acordo com seus achados, que a exposição por 60 segundos é recomendável ao se utilizar fonte de luz com densidade de $400 \mathrm{~mW} / \mathrm{cm}^{2}$. Também enfatizaram a importância da espessura da camada de material não exceder $2 \mathrm{~mm}$, sendo ideal que os incrementos apresentem $1 \mathrm{~mm}$ de espessura, e que fontes com densidade mais baixa que $233 \mathrm{~mW} / \mathrm{cm}^{2}$ não deveriam ser empregadas na fotopolimerização dos compósitos pois podem prejudicar as propriedades finais da restauração.

BARGHI; BERRY; HATTON ${ }^{6}$, em 1994, pesquisaram os fatores que deveriam ser mais bem controlados pelo clínico no sentido de assegurar a qualidade das restaurações polimerizadas com aparelhos de lâmpada halógena. Visto que, apesar da comprovada eficiência, estes aparelhos dependem de constantes cuidados, observou-se muitas irregularidades na rotina dos consultórios quanto a estes fatores. Os dentistas em consultórios particulares utilizam aparelhos fotopolimerizadores inadequados e muitos desconhecem que a densidade de potência apresentada por seus aparelhos é insuficiente para polimerizar completamente a resina composta. Os autores avaliaram 209 aparelhos em uso nos consultórios odontológicos. As leituras foram relacionadas 
ao tipo do aparelho, ao fabricante, à freqüência de uso, à condição da unidade, à idade, à freqüência de troca do bulbo, à potência em watts do bulbo e à satisfação do profissional com o aparelho. Concluiu-se que 30\% dos aparelhos possuíam uma saída de densidade menor que $200 \mathrm{~mW} / \mathrm{cm}^{2}$, valor inadequado para propiciar polimerização suficiente. Para os aparelhos dotados de lâmpada halógena, a densidade de potência é inversamente proporcional à idade da unidade, $10 \%$ possuíam filtros rachados ou com bolhas e muitos dos dentistas nunca haviam trocado a lâmpada de seus aparelhos. O grau de polimerização é, em grande parte, responsável pela qualidade estética o comportamento clínico do material. Variáveis como cor, tipo de compósito, fonte de luz e distância devem ser consideradas quando se examina a densidade de potência de uma unidade fotopolimerizadora e o grau de conversão de monômeros.

HARRINGTON; WILSON ${ }^{33}$, em 1995, publicaram um trabalho em que descreviam as características de algumas unidades de fotoativação (Caulk; Optilux; Luxor e Prismetics). Em sua pesquisa, procuraram avaliar a estabilidade que os aparelhos apresentavam em sua densidade de potência depois de repetidos usos, a variação da densidade em relação à distância fonte de luz/material e também à área de material a ser polimerizada, assim como a profundidade de polimerização alcançada com a utilização das fontes de luz testadas. Seus resultados mostraram que para ativações de $20 \mathrm{~s}$, pelo menos $45 \mathrm{~s}$ de espera antes de uma próxima utilização do aparelho deveria ser respeitada para não haver queda na potência; a distância da ponteira influenciou substancialmente a densidade de potência que atingiu o material fotoativado e o 
diâmetro da ponteira não influenciou na área fotopolimerizada para o aparelho Luxor. Os autores ainda observaram que a irradiância das unidades diminuiu com o uso contínuo devido ao considerável aumento na temperatura verificado em todas as unidades testadas. Por fim, concluíram que uma maior densidade de potência, não sugere necessariamente uma melhor profundidade de polimerização.

CAUGHMAN; RUEGGEBERG; CURTIS JUNIOR ${ }^{12}$, em 1995, publicaram uma revisão de literatura para o clínico, que tratava dos efeitos das técnicas restauradoras relacionadas à fotopolimerização em odontologia. Os autores afirmavam que o processo depende da intensidade de irradiação e sua duração, sendo estes fatores que podem ser controlados pelo clínico, já que com a evolução dos aparelhos de luz halógena, pode-se adquirir equipamentos com boa densidade de potência e com possibilidades de correto controle do tempo de exposição. Os fatores que afetam a intensidade de irradiação dentro do compósito são a espessura do material, sua composição e cor. Destes, a espessura do material é o mais importante, podendo ser controlado pelo clínico e é um fator chave na determinação do sucesso de uma restauração fotopolimerizável. Os autores recomendam incrementos não maiores que $2 \mathrm{~mm}$. Partículas de 0,01 a 1micrometro dispersam a luz porque estes tamanhos são semelhantes ao comprimento de onda emitida pelo aparelho fotoativador. Para cores escuras, que atenuam a emissão de luz, absorvendo-a a medida que passa pelo corpo da restauração, é prudente diminuir o incremento para $1 \mathrm{~mm}$. $O$ esquema de manutenção dos aparelhos deve ser seguido, particularmente aos sinais de 
degradação do bulbo, refletor e ponteira do aparelho. Para autores, a duração da exposição é fator limitante quando a densidade de potência for maior que 280 a $300 \mathrm{~mW} / \mathrm{cm}^{2}$, quando o incremento for de $2 \mathrm{~mm}$ ou menos e a ponteira polimerizadora estiver a menos de $6 \mathrm{~mm}$ da superfície. Materiais polimerizados adequadamente terão uma influência positiva nas propriedades físicas e biológicas da restauração e deverão colaborar para o sucesso clínico.

DUNNE; DAVIES; MILLAR ${ }^{18}$, em 1996, desenvolveram um estudo com os objetivos de pesquisar a densidade de potência de 49 aparelhos fotopolimerizadores em uso clínico e mensurar o efeito na profundidade de polimerização de resinas compostas causado pela alteração na densidade destes mesmos aparelhos. Para esta pesquisa utilizaram um radiômetro para medir a densidade de potência emitida pelas fontes fotoativadoras. A profundidade de cura foi avaliada sobre restaurações de resina composta (Herculite XRV - Kerr) realizadas em primeiros molares humanos, sendo os tempos de irradiância adotados de 20 s e 60 s. Posteriormente, os espécimes foram submetidos ao teste de raspagem do material não polimerizado, de acordo com as especificações da ISO 4049. Os dados encontrados mostraram que as unidades com baixa densidade de potência foram capazes de polimerizar, após 20s de exposição à luz, $1,9 \mathrm{~mm}$ de espessura de resina composta. Ao aumentar o tempo de ativação para $60 \mathrm{~s}$, a profundidade de cura aumentou em $1,4 \mathrm{~mm}$ em relação ao tempo menor, mostrando que a exposição do material por maior tempo pode compensar a perda na potência do aparelho. 
SHORTALL; HARRINGTON ${ }^{68}$, em 1996, publicam um guia para seleção, uso e manutenção de aparelhos fotoativadores e afirmam que densidade de potência adequada e correto espectro de distribuição estão relacionados com boa profundidade de cura e grau de conversão das resinas. A uma espessura de 1 $2 \mathrm{~mm}$ de resina sobreposta, ocorre a redução na densidade de potência e taxa de polimerização. No entanto, somente um pequeno aumento na profundidade de polimerização pode ser esperado se a densidade ou tempo de exposição forem duplicados. Os autores citam que o tempo de ativação de 40s para espessura de $2 \mathrm{~mm}$ parece ser apropriado. Para os aparelhos de lâmpada halógena, a potência da lâmpada varia de 35 a 150W, o que não indica eficiência da mesma. A extensão do espectro de emissão de luz vai de 300 a 1000nm incluindo energia infravermelha e ultravioleta, razão pela qual os fabricantes colocam um filtro entre a lâmpada e o guia de luz para limitar a energia radiante a uma extensão do espectro efetiva para polimerização de materiais fotossensíveis e eliminação do calor produzido, sendo esta na faixa de emissão entre 400 e 500nm.

No estudo realizado por MIYAZAKI et al. ${ }^{50}$, em 1996, foram avaliadas as propriedades mecânicas e as características de polimerização de resinas compostas, por meio de testes de resistência flexural e à fratura. Os compósitos testados foram as resinas Clearfil AP-X (Kuraray), Herculite XRV (Kerr), Palfique Estelite (Tokuyama) e Filtek Z100 (3M/ESPE) e o aparelho fotoativador de lâmpada halógena utilizado foi o Coe-Lite 4000 (Imperial Chemical). Os 
espécimes foram confeccionados de acordo com as recomendações para cada tipo de teste e fotoativados por 30 s com densidade de potência de $400 \mathrm{~mW} / \mathrm{cm}^{2}$, por 60 s com $200 \mathrm{~mW} / \mathrm{cm}^{2}$, ou por $120 \mathrm{~s}$ com $100 \mathrm{~mW} / \mathrm{cm}^{2}$. Após serem armazenados por 24 horas em água a $37^{\circ} \mathrm{C}$, os testes foram realizados. Para todas as propriedades avaliadas, houve diferença entre as resinas testadas. Entre as três condições experimentais de densidade $\mathrm{x}$ tempo empregadas para cada material, não houve diferença significante entre a resistência à fratura, resistência flexural e o módulo flexural, considerando os valores encontrados nestes testes para o mesmo material analisado. Os autores observaram que tanto a resistência flexural quanto a resistência à fratura foram semelhantes quando a densidade de energia, ou seja, a combinação entre densidade de potência e tempo de exposição, foi a mesma. Verificaram também que a baixa densidade de potência exigia um tempo maior de ativação para alcançar os mesmos resultados relativos às propriedades mecânicas.

HARRINGTON; WILSON; SHORTALL ${ }^{34}$, em 1996, desenvolveram um método para determinar o tempo de irradiação apropriado para aparelhos fotopolimerizadores na cura de diferentes resinas compostas e para monitorar a energia de irradiação transmitida pela resina. Usou-se um radiômetro computadorizado e, através de teste de microdureza para a superfície de topo da resina foi possível verificar a validade do método pela performance da fonte de luz em tempo de ativação estipulado comparando-se com 60 s de ativação. Os autores obtiveram, em condições ideais, tempos mínimos de $16 \mathrm{~s}$ a $44 \mathrm{~s}$ para 
polimerizar $2 \mathrm{~mm}$ de espessura para as diferentes combinações de materiais/cor/unidades polimerizadoras. Da mesma forma, observou-se que a duração da irradiação para resinas de diferentes cores, porém do mesmo produto, são similares, provavelmente por terem a mesma composição química e que, frente às médias obtidas, o tempo de 20 s preconizado por alguns fabricantes para $2 \mathrm{~mm}$ de espessura pode ser insuficiente para obtenção de um compósito adequadamente polimerizado.

Em 1997, ARAÚJO; ARAUJO; FERNANDES ${ }^{1}$, realizaram uma pesquisa no sentido de avaliar as condições dos aparelhos fotopolimerizadores utilizados nos consultórios odontológicos e analisar a conscientização dos profissionais quanto aos cuidados que devem ser tomados para se obter uma restauração com o máximo de qualidade. Para isso, avaliaram a densidade de potência, o calor emitido e a influência destes fatores em relação ao tempo de uso dos aparelhos. Foram submetidos a avaliação 105 aparelhos fotoativadores dos quais 60 foram considerados novos (uso $<5$ anos) e 45 antigos (uso > de 5 anos), totalizando 20 modelos diferentes. Foi utilizado o radiômetro para medir a densidade de potência emitida e o calorímetro para analisar o aquecimento do aparelho. De acordo com os resultados obtidos, os autores concluíram que os aparelhos mais novos irradiam menor quantidade de calor e densidade de potência mais alta, sendo que $75 \%$ destes apresentaram-se adequados para o uso rotineiro, enquanto que somente $11,1 \%$ dos aparelhos antigos encontravam-se com bom estado de uso. 
Com o intuito de investigar a correlação entre a distância da ponteira da fonte de luz e o material resinoso e a profundidade de polimerização obtida no processo de fotoativação, HANSEN; ASMUSSEN ${ }^{32}$, em 1997, realizaram um estudo com algumas unidades de lâmpada halógena. Cavidades classe II com caixa proximal de altura entre 7 e 10mm foram confeccionadas em dentes humanos e as mesmas foram preenchidas com a resina composta Silux Plus (3M). Para a ativação do material, as unidades utilizadas foram Coltolux II (Coltene), LC-80 (Lysta), Translux CL (Kulzer) e Visilux 2 (3M). O tempo de irradiância adotado foi de 40 segundos, variando a distância da fonte de luz para os diferentes grupos $(0,2,4,6,9,12,18$ ou 30mm). Após cinco minutos da fotoativação, os espécimes foram submetidos ao teste de raspagem do material não polimerizado e de dureza para avaliação da profundidade de cura. Observouse que a profundidade de cura diminuiu proporcionalmente ao aumento da distância de irradiação e que distâncias a partir de $12 \mathrm{~mm}$ mostraram não polimerizar adequadamente o compósito em espessura acima de $1 \mathrm{~mm}$ quando comparado com a fotoativação com íntimo contato entre fonte e material. Desta forma, os autores sugerem que as restaurações adesivas, mesmo em cavidades proximais profundas, podem ser suficientemente polimerizadas se os critérios para este procedimento forem respeitados, como uso de uma fonte de luz efetiva, finas camadas de material e, se necessário, tempo prolongado de exposição.

NOMOTO $^{51}$, em 1997, avaliou a influência do comprimento de onda na polimerização das resinas compostas fotopolimerizáveis e definiu o mais 
adequado para a polimerização com uma resina experimental e um aparelho de luz visível. Mediu-se a densidade de potência por meio de um radiômetro (LI190S, Li-Cor Inc.); utilizando-se, para a seleção do comprimento de onda, um filtro de banda estreita e um filtro de densidade neutra. O pico máximo de absorção para a $\mathrm{CQ}$ foi de $467 \mathrm{~nm}$, sendo que o grau máximo de conversão ocorreu a 470nm. Na faixa de extensão de 450-490nm o grau de conversão é fracamente sensível ao comprimento de onda. Os autores afirmam que a densidade de potência dentro desta extensão é mais importante do que o pico de comprimento de onda. Fora desta extensão, entretanto, a dependência do comprimento de onda é muito mais forte e a taxa de conversão diminui rapidamente. Conseqüentemente, a densidade e comprimento de onda ótimos para polimerização por um aparelho fotopolimerizador ideal deveria se localizar dentro da extensão 450-490nm, para os compósitos que possuem a canforoquinona como fotoiniciador. Com 5s de exposição, ambos, grau de conversão e conversão de polimerização, foram afetados pelo comprimento de onda porque a absorbância da canforoquinona afeta fortemente a polimerização, especialmente no estágio inicial. O autor enfatiza que a densidade de potência no comprimento de onda de $470 \mathrm{~nm}$ pode ser um guia para eficiência em polimerização. Somente aqueles comprimentos de onda fortemente absorvíveis pelo fotoiniciador são úteis na fotopolimerização.

MEHL et al. ${ }^{46}$, em 1997, avaliaram a pré-polimerização com baixa densidade de potência, seguida da pós-polimerização em intensidade 
convencional, para analisar a adaptação marginal atingida com este procedimento. As propriedades físicas do material como módulo flexural, resistência flexural e dureza Vickers foram investigadas. Os corpos-de-prova de resina composta (Charisma ou Tetric) foram confeccionados e ao serem fotoativados inicialmente, adotou-se uma variação da distância entre a fonte de luz e o material para alterar a densidade de potência nesta fase da ativação. As distâncias utilizadas foram de 0, 2, 4, 6, 8, 10, 20 e 50mm, sendo que a primeira representava $100 \%$ da potência do aparelho $\left(450 \mathrm{~mW} / \mathrm{cm}^{2}\right)$ e as demais corresponderam respectivamente a $80,70,62,56,50,37$ e $13 \%$ da densidade total. Esta polimerização foi total para o grupo controle $(0 \mathrm{~mm})$ e aos demais grupos a ativação inicial foi de 20 s e seguida da ativação por 40 s em alta densidade (100\%). Posteriormente, os espécimes foram submetidos aos testes propostos. Os resultados mostraram que a redução da densidade de potência inicial não influenciou nas propriedades avaliadas de módulo flexural, resistência flexural e dureza, sendo que houve uma melhor integridade marginal comparado aos sistemas de polimerização com alta potência. Desta forma, os autores concluíram que o alto grau de adaptação alcançado nas condições experimentais testadas permitiu um escoamento mais favorável do material para o alívio das tensões internas.

SHORTALL; HARRINGTON ${ }^{69}$, em 1997, realizaram um estudo para investigar a efetividade de unidades fotoativadoras recarregáveis e sua habilidade em sustentar uma alta densidade de potência após sucessivas recargas. Para 
isto, três aparelhos com bateria (Arcus - Litema Dental; Vivalux Ivoclar/Vivadent; Prolite - Dentsply) foram utilizados e o aparelho Heliolux GTE (Ivoclar/Vivadent) foi adotado como controle na pesquisa, sendo que todos tiveram suas densidades de potência mensuradas com um radiômetro. Espécimes de resina composta foram confeccionados ( $\varnothing$ de $4 \mathrm{~mm}$ ) e fotoativados por 40s para que a profundidade de polimerização fosse avaliada por meio de um penetrômetro. Os autores puderam notar com os resultados obtidos que, a profundidade de polimerização foi significantemente maior para a resina composta híbrida. Observaram que a densidade de potência diminuiu após um período de descarga da bateria para dois dos aparelhos testados (Arcus e Vivalux), sendo que estes dados se relacionaram com a profundidade de polimerização encontrada. Entretanto os autores ressaltam que muitos fatores, incluindo o tamanho da peça de mão e seu peso, devem ser considerados na escolha de uma unidade fotoativadora, além de seu custo e capacidade de reutilização.

Em 1997, PEREIRA et al. ${ }^{53}$, avaliaram a capacidade de polimerização por meio de testes de dureza Vickers, de uma única resina composta, em função de diferentes densidades de potência e profundidades de polimerização. Foram selecionados 120 aparelhos fotoativadores, de diferentes modelos e marcas comerciais, dos quais foram registrados os valores de densidade emitida com um radiômetro. Foram confeccionados espécimes com resina Heculite $\mathrm{XR}$, em um único incremento polimerizado por 40 segundos e armazenado à temperatura de $37 \pm 2^{\circ} \mathrm{C}$ durante 24 horas. Decorrido o período de armazenagem, procedeu-se ao 
teste de dureza. Os resultados demonstraram uma relação diretamente proporcional entre dureza e densidade de potência, sendo que os aparelhos que emitem maior densidade proporcionam maior capacidade de fotopolimerização, e, somente aqueles que emitem $800 \mathrm{~mW} / \mathrm{cm}^{2}$ fornecem uniformidade de polimerização em até $4 \mathrm{~mm}$ de profundidade.

FUJIBAYASHI et al. ${ }^{28}$, em 1998, realizaram um estudo com dois aparelhos à base de diodos emissores de luz que ainda não haviam sido lançados no mercado, comparando-os com uma fonte de luz dotada de lâmpada halógena (Optilux - Demetron). Para isto, utilizou a resina composta Silux Plus (3M/ESPE) para investigar a profundidade de polimerização e o grau de conversão obtido com os diferentes aparelhos. Os corpos-de-prova foram confeccionados de acordo com a ISO 4049, apresentando espessura de $8 \mathrm{~mm}$, os quais foram fotoativados pelos tempos de 10, 20, 40 e 60 segundos. Posteriormente, tiveram sua profundidade de polimerização avaliada por meio da raspagem de material amolecido na base do espécime e também foram submetidos ao teste de espectroscopia por infravermelho (Fourier) para análise do grau de conversão. Os resultados mostraram que o aparelho de LED2 que apresentava seu pico de emissão de luz em 466nm demonstrou melhor desempenho que o LED1 (444nm) e o aparelho de lâmpada halógena em relação à profundidade de polimerização. No que diz respeito ao grau de conversão, a fonte de luz que se mostrou com melhores resultados também foi o LED2, permitindo aos autores concluírem que a 
irradiância do LED é efetiva na polimerização de resinas compostas e, portanto, este aparelho pode ser utilizado como fonte de luz.

MARTIN ${ }^{43}$, em 1998, realizou um estudo com o propósito de avaliar a eficiência das unidades de luz visível utilizadas na fotopolimerização em clínicas australianas. As informações obtidas nesta pesquisa foram colhidas por meio de visitas aos dentistas e se constituem do tipo e tempo de uso do aparelho, história de sua manutenção, troca de seus componentes e leitura da sua densidade de potência. O autor pode observar que, dos 214 aparelhos pesquisados, aproximadamente $27 \%$ registravam densidade de potência igual ou inferior a $200 \mathrm{~mW} / \mathrm{cm}^{2}$, um nível que é considerado inadequado para incrementos de resina composta com espessura de $2 \mathrm{~mm}$. Outros $26 \%$ apresentaram-se com densidade entre 201 e 399mW/cm², o que também pode ser considerado aceitável para a fotopolimerização, embora não seja ideal, o que torna ainda mais preocupante o fato de que $44 \%$ dos dentistas entrevistados relataram utilizar um tempo de ativação de 20 s ou menos. Outra preocupante questão foi verificar que $50 \%$ dos profissionais incluídos na pesquisa disseram nunca ter mensurado a densidade de potência de seus aparelhos. Isto mostra que a maioria dos fotopolimerizadores não se apresentava em condições satisfatórias de funcionamento, o que induziu o autor a concluir que muitos profissionais não estão conscientes da necessidade de manutenção e checagem regular da potência dos aparelhos que utilizam em seus procedimentos restauradores. 
KORAN; KÜRSCHNER ${ }^{37}$, em 1998, examinaram os efeitos da técnica de polimerização em duas etapas (baixa e alta densidade de potência) na dureza de superfície, na adesão, na contração, na viscosidade e na concentração de monômeros residuais na resina composta (Pertac). Foi encontrado pelos autores que a polimerização gradual não afeta a contração, nem a dureza e a quantidade de monômeros residuais, quando comparada com a técnica convencional de ativação do material. Puderam concluir desta forma, que a técnica testada proporciona propriedades físicas e mecânicas satisfatórias, assim como melhora a adaptação marginal em função do escoamento do material durante a polimerização.

Com o objetivo de verificar a hipótese de que uma unidade de fotopolimerização, emitindo luz azul de diodo (LEDs) pode produzir uma profundidade de polimerização equivalente a uma unidade de lâmpada halógena, MILLS; JANDT; ASHWORTH ${ }^{48}, 1999$, utilizaram três resinas compostas (Silux Plus U, P-50 U e Filtek Z100 $\left.A_{3,5}\right)$ e uma matriz metálica medindo $4 \mathrm{~mm}$ de diâmetro e $6 \mathrm{~mm}$ de profundidade, para confeccionar os corpos-de-prova. Duas unidades fotoativadoras (Coltolux 4 e LEDs) foram utilizadas e as resinas fotoativadas pelos tempos de 40,60 , e 40 s, respectivamente, de acordo com as recomendações do fabricante, com uma ou outra unidade de fotoativação. A profundidade de polimerização foi medida pelo uso de um penetrômetro. A partir dos resultados encontrados, os autores puderam concluir que a unidade de LED com uma irradiância de $64 \%$ da unidade de lâmpada halógena mostrou uma 
profundidade de polimerização significantemente mais alta. O espectro da luz emitida pode ser considerado, juntamente com a densidade de potência, como indicador de sua efetividade. O uso das unidades de LEDs pode apresentar um potencial para o uso na clínica, devido à efetividade não ser reduzida com o tempo, como acontece com os aparelhos de lâmpada halógena.

Com o objetivo de comparar o efeito da polimerização nas propriedades físicas de três materiais resinosos (Tetric $A_{3}$, Compoglass $A_{3}$ e Filtek Z100 $A_{3,5}$ ), com uma fonte de luz convencional dotada de lâmpada halógena (Aristolite) e uma fonte de luz à base de diodo com arranjo de seis LEDs, WHITTERS; GIRKIN; CAREY ${ }^{79}$, em 1999, realizaram testes de microdureza Knoop, além de utilizar uma técnica de transmissão de sons para medir o tempo de polimerização para os três materiais testados, quando expostos às duas fontes de luz. Além disso, verificaram a contração de polimerização e a mudança de temperatura que ocorre na superfície dos materiais testados durante a fotoativação com ambas as fontes de luz utilizadas. Os autores puderam determinar que um arranjo de seis LEDs foi capaz de promover uma polimerização mais rápida dos materiais restauradores, quando comparada à fonte de lâmpada halógena. No que diz respeito a microdureza e a contração de polimerização, foram encontrados resultados similares para as duas fontes, porém, a mudança de temperatura dos materiais, durante o processo de polimerização, demonstrou-se mais baixa pela utilização do aparelho de LED. Com base nestes achados, os autores relatam que esta 
nova fonte de polimerização pode ser um novo instrumento efetivo para polimerizar materiais sensíveis à luz, especialmente as resinas compostas.

RUEGGEBERG ${ }^{62}$, em 1999, publica uma revisão sobre o processo de polimerização, variedades de aparelhos fotopolimerizadores existentes no mercado e as diferenças entre as filosofias pertinentes à polimerização. Neste trabalho, cita que a tendência é que o rótulo da resina composta traga informações sobre a energia necessária para a polimerização. Da mesma forma, o aparelho fotopolimerizador deve indicar a densidade de potência e comprimento de onda emitido. O espectro necessário para uma resina deve combinar com o espectro de luz emitido pelo aparelho, pois do contrário, não haverá fotopolimerização. $O$ autor define um conceito sobre energia total de polimerização. A analogia é feita com um filme fotográfico, onde o tempo de exposição é variado de acordo com as condições de luz do ambiente e com a sensibilidade do filme a ser usado (a ASA ou o número ISO). Um filme mais sensível vai necessitar de tempos de exposição mais curtos em níveis menores de iluminação do que filmes de menor sensibilidade. Para calcular esta energia total, é necessário saber a intensidade da unidade fotopolimerizadora (em $\mathrm{mW} / \mathrm{cm}^{2}$ ) e a duração do tempo de exposição (em segundos). Considerando-se uma resina que necessite de uma exposição de 40 s a $600 \mathrm{~mW} / \mathrm{cm}^{2}$ para propiciar adequada polimerização em $2 \mathrm{~mm}$ de profundidade, o total de energia concedida a este material é o produto de $40 \mathrm{~s} \times 600 \mathrm{~mW} / \mathrm{cm}^{2}$ ou $24000 \mathrm{~mJ} / \mathrm{cm}^{2}\left(24 \mathrm{~J} / \mathrm{cm}^{2}\right)$. Desta 
forma, qualquer combinação de exposição e intensidade que resulte em $24 \mathrm{~J} / \mathrm{cm}^{2}$ deve propiciar a mesma quantia de polimerização.

JANDT et al. ${ }^{35}$, em 2000, como primeiro objetivo, verificaram a hipótese de que a profundidade de polimerização e resistência à compressão de resinas compostas fotoativadas com uma unidade de fotopolimerização à base de diodo ou uma unidade de lâmpada halógena convencional, não diferem significantemente, e como segundo objetivo, os autores verificaram as características da irradiância e do espectro da luz emitida por ambas fontes de luz. Para isto, os autores utilizaram uma única resina composta (TPH nas cores $A_{2}$ e $A_{4}$ ), que foi fotoativada pelas duas unidades por tempo de 40 segundos. $A$ profundidade de polimerização foi medida em 10 espécimes com $4 \mathrm{~mm}$ de diâmetro e $8 \mathrm{~mm}$ de profundidade, com o auxílio de um penetrômetro. Para o teste de resistência à compressão, foram confeccionados 6 corpos-de-prova com $4 \mathrm{~mm}$ de diâmetro e $6 \mathrm{~mm}$ de profundidade, para cada cor de resina. $O$ teste de resistência à compressão foi determinado após 6 e 72 horas. Como resultados, os autores puderam observar que a fonte de lâmpada halógena polimerizou a resina composta em maior profundidade. No entanto, ambas as unidades promoveram uma polimerização em maior profundidade do que a recomendada pelas normas da ISO 4049 e pelo fabricante do material. No que se refere a resistência à compressão, não foram observadas diferenças significantes tanto entre os espécimes armazenados por período de 6 e 72 horas como para as diferentes cores do material. O espectro de luz emitido pelas unidades fotoativadoras diferiu 
fortemente. Frente a isso, os autores concluíram que a profundidade de polimerização e a resistência compressiva da resina composta avaliada, ao ser polimerizada pelas duas fontes de luz, excederam os valores recomendados pelas especificações do fabricante e pelas necessidades clínicas e que a unidade de diodos emissores de luz (LED) pareceu ter um maior potencial para a aplicação clínica futura, quando comparada à unidade de lâmpada halógena.

Com o objetivo de determinar quanto de densidade de energia seria capaz de penetrar em algumas marcas comerciais de resinas compostas e na dentina humana, PRICE; MURPHY; DÉRAND ${ }^{58}$, em 2000, realizaram um estudo com dois tipos de ponteiras (padrão e turbo), que apresentavam diâmetros diferentes e, portanto, uma saída de luz em diferentes densidades de potência. O aparelho fotoativador utilizado nesta pesquisa foi o Optilux 500 (Demetron/Kerr) que apresentava saída de luz padrão de $8 \mathrm{~mm}\left(682.1 \mathrm{~mW} / \mathrm{cm}^{2}\right)$ e quando nele era acoplada a ponteira turbo, esta apresentava uma saída de $13 \mathrm{~mm}\left(1014 \mathrm{~mW} / \mathrm{cm}^{2}\right)$. Os corpos-de-prova foram confeccionados com as resinas Filtek Z100 (3M/ESPE), Pertac II (ESPE), Prodigy (Kerr), Surefil (Dentsply), Prodigy Condensable (Kerr), Filtek P60 (3M/ESPE) e Alert (Jeneric/Pentron), nas espessuras de $0,5 \mathrm{~mm}, 1 \mathrm{~mm}, 2 \mathrm{~mm}, 3 \mathrm{~mm}, 4 \mathrm{~mm}$ e $5 \mathrm{~mm}$. Os espécimes de dentina foram obtidos de molares humanos e apresentavam espessura de $5,85 \mathrm{~mm}$. Os resultados encontrados mostraram que, para todos os espécimes analisados, houve uma diminuição exponencial na luz transmitida, à medida que aumentava a espessura de material ou estrutura dentária. Também foi observado que cerca de $42 \%$ mais energia foi transmitida quando a ponteira-turbo foi adaptada ao 
aparelho. Embora isto possa ter sido notado, os autores consideram que mesmo com o uso de alta densidade de potência, a energia pode ser insuficiente para polimerizar adequadamente os materiais resinosos quando a espessura for maior que $2,5 \mathrm{~mm}$ e quando houver mais de $2 \mathrm{~mm}$ de dentina para a luz penetrar.

Ainda em 2000, SANTOS et al. ${ }^{67}$ avaliaram o grau de polimerização da resina por meio de testes de microdureza Knoop. Utilizou-se de três aparelhos fotoativadores (Optilight II/Gnatus, XL 1500/3M e Fibralux/Dabi Atlante), os quais foram usados para polimerizar os espécimes da resina Z100 confeccionados com matriz de poliacetato e testados no microdurômetro HMV 2000 SHIMADZU. Desta forma, foi verificado que para melhores resultados de dureza, é necessário densidade de potência superior a $400 \mathrm{~mW} / \mathrm{cm}^{2}$, mostrando uma relação direta entre densidade e profundidade de polimerização. Para o tempo de 40 segundos de ativação, a microdureza foi maior que com 20s para os três aparelhos. E, concluiu-se ainda que, os aparelhos fotoativadores do tipo pistola (XL 1500 o Optilight II) promoveram maior microdureza que o aparelho tipo cabo (Fibralux).

STAHL et al. ${ }^{72}$, em 2000 , se propuseram a avaliar a resistência flexural de resinas compostas fotoativadas com diferentes fontes de luz, sendo um aparelho do tipo LED $\left(350 \mathrm{~mW} / \mathrm{cm}^{2}\right)$ e um aparelho de lâmpada halógena $\left(755 \mathrm{~mW} / \mathrm{cm}^{2}\right)$. A unidade de LED testada neste estudo pertencia à $1^{a}$ geração desta tecnologia de aparelhos e possuía 27 LEDs azuis. Os compósitos analisados foram Spectrum 
TPH, Z100 e Solitaire, em várias cores, do quais foram obtidos espécimes fotopolimerizados com os diferentes aparelhos e submetidos aos testes de resistência flexural. Os resultados encontrados mostraram que ambas fontes de luz proporcionaram valores de resistência superiores ao mínimo recomendado pela ISO e semelhantes entre si. Os autores enfatizaram neste estudo que a tecnologia LED é uma alternativa satisfatória para a fotopolimerização de resinas compostas. Numa tentativa de explicar os resultados alcançados com o LED, aparelho cuja densidade de potência era 2,2 vezes menor que da luz halógena, demonstraram que a energia emitida no espectro de absorção da luz pela canforoquinona foi o dobro do apresentado pelo aparelho convencional, portanto, concluíram que o LED poderia ser aceito para utilização na cura dos materiais resinosos.

Em 2000, TURBINO; SANTOS; MATSON ${ }^{75}$, avaliaram a microdureza Knoop da resina composta Z100 (3M) a uma profundidade de $3 \mathrm{~mm}$ com espécimes confeccionados em duas matrizes de polipropileno, uma branca e outra preta. Os espécimes foram levados ao microdurômetro HMV 2000 SHIMADZU, e os resultados mostraram que a microdureza foi menor com a matriz escura. Além disso, entre as técnicas de inserção e polimerização, a técnica do incremento único induziu a menores graus de polimerização que a técnica incremental, em ambas as matrizes. Devido à direta correlação entre a densidade de potência com a dureza do material e a profundidade de polimerização, resultados que envolvam esses fatores de variação podem ter seus valores deformados conforme o tipo de matriz experimental utilizada. 
Portanto, a cor da matriz experimental adotada para a confecção dos espécimes exerceu influência nos valores de microdureza.

Como muitos aparelhos têm sua efetividade de uso diminuída com o tempo de uso, PEREIRA et al. ${ }^{54}$, em 2000 , buscaram avaliar a profundidade de polimerização de cinco aparelhos fotoativadores em uso na Faculdade de Odontologia da Universidade Estadual do Rio de Janeiro. As unidades Heliomat II A, Heliomat II B, Optilux, Optilight e 'R e M', foram testadas quanto a sua emissão de luz por meio de um radiômetro, aplicando tempo de ativação de 40 segundos e o teste repetido cinco vezes para cada aparelho. Em relação à profundidade de polimerização, foram confeccionados corpos-de-prova de resina composta de $11 \mathrm{~mm}$ de espessura e fotoativados por $40 \mathrm{~s}$, sendo que em seguida, foram submetidos ao teste de raspagem da porção de material não-polimerizado e ao teste de microdureza superficial e de base. Os resultados mostraram que houve uma correlação entre a densidade de potência obtida no radiômetro e a profundidade de polimerização alcançada nos testes, ou seja, aqueles aparelhos que apresentaram maior comprimento de onda e maior irradiância foram capazes de polimerizar a resina composta em maior profundidade, embora os testes tenham mostrado que para todas as fontes, as porções mais profundas do material são afetadas pela pobre densidade de potência, principalmente acima de $2 \mathrm{~mm}$ de espessura. 
KNEZEVIC et al. ${ }^{36}$, em 2001, realizaram um estudo com o objetivo de comparar o grau de conversão e a elevação da temperatura de quatro resinas híbridas (Tetric Ceram, Pertac II, Valux Plus e Degufill Mineral) após a irradiação por 40 segundos com 2 aparelhos convencionais (Heliolux GTE, Elipar Highlight soft-start) e 1 LED (16 unidades LEDS - sem marca comercial) sobre a superfície do material com $1 \mathrm{~mm}$ de espessura. Os resultados mostraram que o maior grau de conversão foi atingido como aparelho de lâmpada halógena (Heliolux e Elipar Highlight), sendo que a resina com o maior grau de conversão foi a Pertac II. A maior elevação de temperatura foi observada com o aparelho convencional Heliolux GTE e a menor temperatura foi com o LED $\left(12 \mathrm{~mW} / \mathrm{cm}^{2}\right)$. Desta forma, os resultados obtidos no estudo evidenciaram que o LED experimental de densidade mínima e comprimento de onda de $470 \mathrm{~nm}$ foi promissor, especialmente, no que diz respeito à pequena elevação na temperatura dos espécimes de resina composta. Para assegurar suficiente densidade de potência para melhorar os valores do grau de polimerização é necessário utilizar um número maior de unidades de LED e concentrar sua luz.

Com o objetivo de investigar o efeito da taxa de polimerização sobre as propriedades mecânicas de uma resina composta experimental de formulação semelhante a dos compósitos comercialmente disponíveis $(75 / 25 \%$ bisGMA/TEGDMA), LOVELL et al. ${ }^{42}$, em 2001, realizaram um estudo do grau de conversão por meio de espectroscopia por infravermelho e da variação de temperatura durante a polimerização por análise mecânica dinâmica. Uma fonte 
de luz ultravioleta foi utilizada com comprimento de onda em $365 \mathrm{~nm}$ e as diferentes temperaturas foram avaliadas: $10,20,37,50$ e $70^{\circ} \mathrm{C}$, sendo os tempos de irradiância adotados nestas condições como 39s, 85s, 110s e 150s, respectivamente. Os resultados deste estudo mostraram que o grau de conversão foi diretamente proporcional ao aumento da temperatura durante a cura do material, embora a variação de temperatura não tenha interferido na estrutura das cadeias poliméricas, sugerindo que as propriedades mecânicas são independentes da temperatura de cura, porém bastante dependentes do grau de conversão das duplas ligações. Desta forma, os autores concluíram o perfil de polimerização que conduz à conversão final não afeta as propriedades da rede polimérica, sendo tal resultado atribuído à alta densidade de ligações cruzadas no polímero.

KURACHI et al. ${ }^{38}$, em 2001, avaliaram a dureza de uma resina composta polimerizada por dois (L2 - $\left.25 \mathrm{~mW} / \mathrm{cm}^{2}\right)$, três $\left(\mathrm{L} 3-34 \mathrm{~mW} / \mathrm{cm}^{2}\right)$, quatro (L4 $\left.46 \mathrm{~mW} / \mathrm{cm}^{2}\right)$, cinco $\left(\mathrm{L} 5-68 \mathrm{~mW} / \mathrm{cm}^{2}\right)$ ou seis $\left(\mathrm{L} 6-79 \mathrm{~mW} / \mathrm{cm}^{2}\right)$ LEDs azuis (Nichia Chemical Ind, 2000mcd, Japão) e compararam com a unidade de lâmpada halógena (K\&M, 200R, São Carlos, Brasil) de $475 \mathrm{~mW} / \mathrm{cm}^{2}$. As medidas de potência foram feitas por um medidor científico (Field Master, Coherent, USA). A resina composta (Z100 cor A3) foi polimerizada por 20, 40, 60, 120 e 180s com cada base de LEDs e por 40s com o aparelho convencional. Prepararam-se cinco amostras de resina composta para cada grupo, nas espessuras de 0,35, 1,25 e 1,8mm. Realizou-se a avaliação da dureza na superfície não irradiada, por meio 
de três endentações para cada amostra. Todas as amostras polimerizadas pelo LED apresentaram dureza inferior quando comparadas à unidade de lâmpada halógena no tempo típico de 40s. A unidade L6 foi a mais eficiente, no entanto tempos de exposição mais longos ou camadas mais finas de resina foram necessárias. Usando-se o L6 com 40s de exposição para incrementos de 0,7mm de espessura o número de dureza Vickers igual a 100 foi obtido. Apesar da diferença de irradiação quando comparado com a fonte de lâmpada halógena, o LED mostrou-se uma promissora alternativa na polimerização de resinas compostas, principalmente porque, quase a totalidade da energia emitida esteve dentro da extensão ideal de absorção para a canforoquinona.

Para avaliar o efeito da polimerização com arco de plasma nas propriedades das resinas compostas fotoativáveis, MILLAR; $\mathrm{NICHOLSON}^{47}$, em 2001, realizaram um estudo comparando um aparelho convencional de lâmpada halógena (Euromax) e uma unidade de arco de plasma (Apollo 95E). Tais aparelhos foram utilizados para fotoativar quatro grupos de espécimes de $2,8 \mathrm{~mm}$ de espessura de resina composta entre outros materiais pelos tempos de exposição de 20 ou 30s (halógena) e 1 ou 2s (arco de plasma). Após serem armazenados em água deionizada, os espécimes foram analisados quanto a sorpção de água e perda de massa. A maior perda de massa nos grupos polimerizados com arco de plasma sugeriram sua menor efetividade de cura, pois os materiais exibiram diferente solubilidade e propriedades mecânicas quando comparado com a polimerização realizada com a fonte convencional. Desta 
forma, os autores relataram que a durabilidade dos materiais submetidos a fotoativação com aparelhos de arco de plasma seria menor que da fonte de lâmpada halógena e que outros estudos deveriam ser realizados para avaliação in vivo.

DUKE $^{19}$, em 2001, relatou sobre a utilização dos aparelhos à base de diodos emissores de luz na polimerização das resinas compostas, enfatizando suas aplicações na odontologia, suas principais características, além das vantagens apresentadas sobre as unidades dotadas de lâmpada halógena. Cita que o LED demonstra maior relação eficiência-custo com vida útil mais longa quando comparado com os aparelhos convencionais. Apresentam-se como equipamentos portáteis, sem fio e de construção mais refinada e delicada. A geração de calor parece ser menor, permitindo seu uso mais extenso na rotina do consultório. Afirma que as propriedades físicas dos materiais polimerizados com LED são equivalentes ou melhores que as proporcionadas pela luz halógena. Não necessitam de sistema de ventilação, sua densidade de potência não decresce com o passar do tempo e podem ser utilizados com baterias. Por fim, reporta que esta tecnologia está embasada em investigações que estabeleceram as primeiras descobertas de ser uma fonte de luz capaz de ser utilizada na cura dos materiais resinosos, considerando que estes aparelhos devem ser explorados em pesquisas para constatar sua real eficácia. 
YAP; SENEVIRATNE ${ }^{80}$, em 2001, investigaram a influência da densidade de energia (densidade de potência $x$ tempo de irradiância) na efetividade da polimerização da resina composta, por meio de testes de microdureza nas superfícies de topo e base do material. Os espécimes apresentavam $2 \mathrm{~mm}$ de espessura e foram ativados pelos tempos de 20, 30, 40, 60, 80, 100, 120 e 180s. As densidades de potência empregadas neste estudo foram 200, 300, 400, 500 e $600 \mathrm{~mW} / \mathrm{cm}^{2}$. Os valores médios de microdureza foram padronizados como os obtidos pela combinação $400 \mathrm{~mW} / \mathrm{cm}^{2}$ por tempo de 40 s que foi considerado o grupo controle da pesquisa. Os resultados mostraram que a dureza adequada para a superfície de topo da resina poderia ser obtida com 20 s de irradiância a baixas densidades de potência $\left(200\right.$ e $\left.300 \mathrm{~mW} / \mathrm{cm}^{2}\right)$. Em relação à superfície de base, a polimerização ideal somente foi alcançada em baixas densidades quando o tempo de ativação foi de 120 s, ou ao ser empregada uma alta intensidade de luz (500 e $600 \mathrm{~mW} / \mathrm{cm}^{2}$ ) por tempo menor (30s). Com tais achados, os autores concluíram que mais pesquisas devem ser realizadas para estabelecer a densidade de energia ideal requerida pelos aparelhos fotopolimerizadores, principalmente as novas fontes de luz lançadas no mercado odontológico.

MEDEIROS ${ }^{45}$, em 2001, apresenta um estudo sistemático de comparação da microdureza Vickers, obtida em espécimes polimerizados com três diferentes fontes de luz, a fim de determinar uma relação de tempo de exposição e profundidade de polimerização para o dispositivo experimental à base de LEDs e sua perspectiva para aplicações clínicas. A resina composta Z100 cor A3 (3M do 
Brasil) foi inserida em incremento único em uma matriz de aço inoxidável, com cilindros de $8 \mathrm{~mm}$ de diâmetro em duas profundidades: 0,7mm e 2,0 mm. Na base da parte cilíndrica uma tira de poliéster foi acomodada para permitir uma maior lisura na superfície oposta à iluminada. Utilizaram-se os aparelhos $\mathrm{LH}-(<200 \mathrm{R}$, K\&M, Brasil ) com potência de $350 \mathrm{~mW}$ e intensidade de $700 \mathrm{~mW} / \mathrm{cm}^{2}$; laser de argônio (LA), linha 488nm, (INNOVA 100, Coherent, EUA) com potência de $500 \mathrm{~mW}$ e intensidade de $1 \mathrm{~W} / \mathrm{cm}^{2}$ e um dispositivo LED em caráter experimental com potência média de $50 \mathrm{~mW}$ e intensidade aproximada de $100 \mathrm{~mW} / \mathrm{cm}^{2}$. Realizou-se a analise estatística dos dados obtidos por meio de análise de variância (ANOVA) e teste de Tukey com $5 \%$ de significância. Os valores de dureza obtidos na face diretamente iluminada (topo) mostraram equivalência entre as três fontes de luz para polimerização, com variação inferior a 10\%, sendo estes valores superiores àqueles obtidos a 0,7 e 2,0 mm de profundidade. Para a espessura de $0,7 \mathrm{~mm}$, a LH, o LED e o LA obtiveram os mesmos valores de dureza Vickers, utilizando-se os tempos de exposição de 40s, 40s e 10s, respectivamente. Para espécimes com espessura de 2,0 $\mathrm{mm}$ um tempo de exposição de 40s foi necessário para obtenção de valores de microdureza equivalentes aos obtidos com a LH em 40s ou com o LA por 10s. Recomenda-se a utilização de 60 s de exposição para incrementos de $2 \mathrm{~mm}$ de espessura com os dispositivos a base de LED.

LEONARD et al. ${ }^{39}$, em 2001, objetivaram determinar o valor mínimo de irradiação requerido para polimerizar resinas compostas híbridas e de 
micropartículas quando polimerizadas por tempo de ativação de 40s e 60 s com uma fonte de luz dotada de lâmpada halógena. Para este estudo, os autores procuraram avaliar a microdureza Knoop dos compósitos testados após serem confeccionados espécimes de $2 \mathrm{~mm}$ de espessura das resinas Z100 e Silux Plus (3M/ESPE) e fotoativados com o Optilux 401 (Demetron) pelos tempos determinados. A microdureza foi medida tanto na superfície de topo como de base dos espécimes e a porcentagem entre os valores foi observada, considerando que um valor de dureza na base que correspondesse a $80 \%$ do valor no topo indicaria uma polimerização satisfatória. Os resultados deste trabalho mostraram que o valor mínimo de densidade de potência de $300 \mathrm{~mW} / \mathrm{cm}^{2}$ recomendado pelos fabricantes dos materiais pode ser adequado para as resinas híbridas, no entanto, mostrou-se insuficiente para as resinas de micropartículas, que necessitaram de densidades superiores a $542,9 \mathrm{~mW} / \mathrm{cm}^{2}$ pelo tempo de exposição de 40s para alcançar o mesmo grau de polimerização que a híbrida.

HAMMESFAHR; O'CONNOR; WANG ${ }^{31}$, em 2002, avaliaram uma variedade de sistemas fotoativadores produzidos para polimerizar os compósitos na tentativa de elucidar as vantagens e desvantagens intrínsecas a cada tipo de aparelho. Os primeiros aparelhos utilizados na fotopolimerização foram os à base de luz ultravioleta, no entanto foram rapidamente eliminados do mercado odontológico por ser esta luz prejudicial aos olhos do operador e do paciente. Frente a isto, surgiram aparelhos à base de luz visível, como as unidades de lâmpada halógena de quartzo-tungstênio, a qual é ainda muito utilizada 
atualmente. Por encontrarem sua emissão de energia em larga faixa de comprimento de onda, são capazes de atingir tanto a canforoquinona como a fenilpropanodiona, os dois fotoiniciadores mais comumente encontrados nas resinas compostas. Sua relativa alta densidade de potência também é uma vantagem por permitir boa polimerização dos materiais fotossensíveis e, a cada novo aparelho surgido no mercado, menor tempo de exposição é necessário para o processo de cura. Entretanto, apresentam algumas limitações, pois perdem a eficiência com o tempo de uso, por degradação de seus componentes devido ao aquecimento do aparelho por dissipação de calor. Outra tecnologia que despontou no mercado foi a da lâmpada de arco de plasma, com intensa emissão de luz. São aparelhos que necessitam de filtragem da luz emitida e ventilação por liberarem grande quantidade de calor. Uma vantagem inicialmente mostrada pelo arco de plasma foi o curto período de tempo despendido na polimerização dos materiais, todavia, a contração dos mesmos era maior, causando sensibilidade e aumentando a infiltração marginal, além de causar danos ao tecido pulpar. As unidades de laser de argônio, embora apresentassem alta intensidade de luz e emitirem energia na faixa de absorção da canforoquinona, não coincidia com o pico de absorção desta sendo, portanto, menos eficiente que as unidades de lâmpada halógena, além disso, os aparelhos não eram portáteis e eram bastante onerosos para o uso em consultório. Por fim, surgiram os aparelhos à base de diodos que emitem luz num espectro bem mais estreito que os demais, atingindo o fotoiniciador em maior intensidade com menor liberação de calor. Apresentam menor densidade de potência e, portanto, a polimerização é mais lenta, diminuindo a contração de polimerização. São unidades mais resistentes, 
menores e mais acessíveis financeiramente, considerando que sua vida útil é bem maior que dos demais sistemas fotoativadores. Os autores concluem que é fundamental aos profissionais conhecerem as características de cada tecnologia para decidirem por qual delas deve optar de acordo com as suas necessidades.

Seguindo esta mesma linha de pesquisa, CHRISTENSEN ${ }^{14}$, em 2002, faz algumas considerações sobre o dilema da fotopolimerização nos dias atuais devido ao vasto sistema de aparelhos fotoativadores disponível na Odontologia. É inquestionável que a fotopolimerização é desejada, no entanto os profissionais ainda estão confusos quanto ao conceito mais apropriado para ser aplicado na prática do consultório. O autor explora as vantagens e desvantagens de vários tipos mais comumente utilizados na fotoativação e sugerem uma maneira lógica de decidir qual aparelho usar. Em relação aos aparelhos de luz halógena convencionais, os quais são baseados numa tecnologia simples e bem conhecida, muitos podem ser ligados na energia comum, geram pouca ou nenhum aquecimento, no entanto, são pesados e relativamente grandes, suas lâmpadas diminuem de potência com o tempo de uso e por isso devem ser trocadas com freqüência por um custo moderado. Mais recentemente, surgiram os aparelhos de luz halógena com regulagem da intensidade de luz de acordo com o tempo de polimerização para tentar minimizar os efeitos da contração de polimerização. Estes apresentam vantagens sobre os convencionais por oferecerem cura mais rápida da resina composta e operarem por meio de tecnologia comprovada e conhecida; suas desvantagens são a geração de calor durante a polimerização, 
algumas marcas apresentam a ponta emissora da luz com diâmetro menor que os convencionais, maior custo, são também pesados e volumosos, com lâmpadas que perdem potência com o tempo, devendo ser trocadas periodicamente. Os aparelhos do tipo LED, surgidos mais recentemente no mercado, operam em intensidade de luz menor, o que gera receio entre os profissionais. Entretanto possuem várias vantagens como apresentarem-se na forma sem fio, pequenos e leves, os LEDs têm longa vida útil, não necessitando serem trocados, não geram calor, permitem polimerização moderada em apenas 10 a 20s. Quanto às suas desvantagens, suas baterias devem ser trocadas, sua tecnologia é ainda bastante nova na Odontologia, precisando ser mais investigada, podem custar mais que os aparelhos de luz halógena convencionais. No caso do arco de plasma de xenônio, por desempenhar uma polimerização rápida da resina composta, muitos dentistas relatam danos à restauração e ao preparo cavitário. Como vantagens, o reduzido tempo de exposição de 3s, diminuindo o tempo clínico despendido; produção de calor maior que os outros aparelhos, sua lâmpada, embora pouco precise ser trocada, quando isto se faz necessário, seu custo é muito elevado, muitas marcas são grandes, pesadas e volumosas. Cada tipo de aparelho apresenta vantagens e desvantagens, mas não há claramente uma tecnologia superior à outra. Desta forma, o autor conclui que o tipo de sistema fotopolimerizador a ser usado pelos dentistas deve estar diretamente relacionado com suas necessidades e preferências. 
$\mathrm{Na}$ tentativa de revisar a performance de diferentes tecnologias em fotopolimerização, BURGESS et al. ${ }^{9}$, em 2002, publicaram um estudo comparando fontes de luz halógena, arco de plasma, laser de argônio e os diodos emissores de luz (LEDs). As unidades de lâmpada halógena são muito populares entre os clínicos por serem relativamente mais acessíveis financeiramente, por apresentarem boa densidade de potência e emitir um largo espectro de luz visível, podendo atingir vários fotoiniciadores presentes na composição das resinas compostas. No entanto, apresentam desvantagens como sua degradação com o tempo de uso, por haver declínio de sua potência devido ao aquecimento do filamento de tungstênio, do desgaste do bulbo e problemas com o filtro que necessita para emitir luz no espectro azul. Se tais fatores não forem periodicamente revisados e a correta manutenção não for dada ao aparelho, seu desempenho pode tornar-se bastante prejudicado. Em relação às unidades de arco de plasma, estas alcançam densidades de potência em torno de $2300 \mathrm{~mW} / \mathrm{cm}^{2}$, dentro do espectro de luz de 380 a $500 \mathrm{~nm}$, porém, o calor gerado por esta fonte pode causar danos ao tecido pulpar durante um procedimento restaurador. Podem ser consideradas ótimas alternativas para fotopolimerização de restaurações indiretas, porém são aparelhos caros e apresentam tamanho inapropriado para o uso em consultório. No que diz respeito ao laser de argônio, os autores citam a geração de luz infravermelha, o que eleva a temperatura do aparelho durante seu uso. Outras limitações do laser seriam seu alto custo, considerável ineficiência na fotopolimerização e o fato de também ocuparem muito espaço, não sendo portáteis. Por fim, os aparelhos do tipo LED já emitem luz no espectro azul, não necessitando de filtros e não gerando energia fora do 
comprimento de onda adequando para a fotopolimerização, o que não causa a geração de calor. Proporcionam melhor grau de polimerização com densidade de potência mais baixa, por emitir luz numa estreita faixa de comprimento de onda que coincide com o espectro de absorção do fotoiniciador, podem ser utilizados com baterias, são portáteis e apresentam vida útil bem mais longa que os demais aparelhos. Frente a isto, os autores relatam que embora as diferentes unidades fotoativadoras apresentem diferenças nos seus modos de cura do material, suas peculiaridades devem ser consideradas e o tipo de resina composta a ser polimerizada deve ser observado para decidir qual tecnologia é mais recomendada.

YOON et al. ${ }^{82}$, em 2002, com a proposta de avaliar a efetividade de polimerização de alguns aparelhos fotoativadores, compararam as tecnologias LED, arco de plasma e halógena convencional quanto ao grau de conversão dos monômeros que estes aparelhos alcançavam quando a mesma densidade de energia total era empregada. Para isto utilizaram as resinas compostas Revolution (Kerr), Surefil (Dentsply) e Filtek Z250 (3M/ESPE), das quais foram confeccionados espécimes de $5 \mathrm{~mm}$ de espessura e polimerizados com as unidades Spectrum 800 (halógena), um LED experimental de arranjo de 37 diodos, sendo para estas duas fontes de luz a densidade de potência de $400 \mathrm{~mW} / \mathrm{cm}^{2}$ e tempo de exposição de 20 s e 40 s, e aparelho o Apollo $95 \mathrm{E}$ (arco de plasma) com densidade de $1472 \mathrm{~mW} / \mathrm{cm}^{2}$ irradiado pelos tempos de $5 \mathrm{~s}$ e $10 \mathrm{~s}$, fixando as densidades de energia em 8 e $16 \mathrm{~J} / \mathrm{cm}^{2}$. Posteriormente, os espécimes foram submetidos à espectroscopia por infravermelho Fourier para análise do 
grau de conversão. Os resultados mostraram que a resina fluida, ou seja, com menor quantidade de carga, quando polimerizada com a luz halógena, apresentou o mais alto grau de conversão. No tempo de 40s, observou-se maior polimerização comparado ao tempo de 20s, exceto para a resina Z250. Em relação ao LED, os tempos de 20 s e 40 s demonstraram similaridade no grau de conversão, enquanto que para o arco de plasma o tempo de 10 s se mostrou mais eficiente que a irradiação por 5 s. Os autores relataram que quando a energia total foi de $8 \mathrm{~J} / \mathrm{cm}^{2}$, todas as unidades apresentaram comportamento semelhante, no entanto, quando a energia foi de $16 \mathrm{~J} / \mathrm{cm}^{2}$, esta similaridade ocorreu em espessuras até $2 \mathrm{~mm}$, pois o grau de conversão diminuiu significantemente com o aumento da espessura do material além de $3 \mathrm{~mm}$.

TARLE et al. ${ }^{73}$, em 2002, tiveram por objetivo avaliar o grau de conversão e a elevação da temperatura de 3 diferentes materiais (Filtek Z250, Tetric Ceram e Pertac II) quando polimerizados com 3 fontes: LED experimental, arco plasma (Apollo $95 \mathrm{E}$ ) e luz halógena (Elipar II). O grau de conversão e a elevação da $\mathrm{T}^{\circ} \mathrm{C}$ foram determinados após 20 e 40s de irradiação para o LED e a luz halógena e para o arco plasma, todos os modos de polimerização foram testados (temperatura controlada após 1, 2, 3, 5, 10, 15 e 20s). Para todos espécimes foram feitas 5 medidas. Para avaliar o grau de conversão, espécimes de $2 \mathrm{~mm}$ de espessura foram confeccionados e testados por meio de espectroscopia por infravermelho. A análise da elevação da Temperatura foi realizada da seguinte forma: espécimes foram confeccionados com as dimensões $4 \times 4 \times 4 \mathrm{~mm}$ em 
matrizes de teflon. Uma ponta para medir a temperatura foi inserida a $2 \mathrm{~mm}$ dentro do espécime e através de um computador a ela conectado, os valores de elevação da temperatura eram detectados. Os resultados mostram que o grau de conversão encontrado para os grupos ativados com a lâmpada halógena foi superior aos demais sistemas fotopolimerizadores e que o aparelho de LED não foi capaz de polimerizar adequadamente todos os compósitos estudados, considerando os incrementos de $2 \mathrm{~mm}$, exceto para a Filtek Z250 após 20s e 40s de ativação e a Tetric após 40s. Com estes achados, os autores concluíram que o aparelho de LED, pela sua melhor distribuição de energia na estreita faixa de comprimento de onda coincidente com a absorção da canforoquinona, pode produzir um efeito similar à unidade de lâmpada halógena e também arco de plasma, que são aparelhos com maior densidade de potência, mesmo apresentando baixa intensidade de luz.

MILLS; UHL; JANDT ${ }^{49}$, em 2002, tiveram o objetivo de avaliar o primeiro LED comercialmente disponível (LuxOMax - 7 unidades LEDs) e construir um LED mais potente (63 unidades) e com ponta de diâmetro de $8 \mathrm{~mm}$, de acordo com os aparelhos utilizados clinicamente. Uma luz halógena foi utilizada como controle na pesquisa, sendo que esta se apresentava com $851 \mathrm{~mW} / \mathrm{cm}^{2}$ de potência, e os LEDs com $119 \mathrm{~mW} / \mathrm{cm}^{2}$ e $666 \mathrm{~mW} / \mathrm{cm}^{2}$, o LuxOMax e o experimental, respectivamente. Foram utilizadas duas cores de resina híbrida (Spectrum TPH A2 e A4), sendo que 10 espécimes de cada resina e combinação com os aparelhos foram confeccionados e polimerizados por 40s em uma matriz 
de $4 \mathrm{mmx} 8 \mathrm{~mm}$. O LED experimental foi usado em duas diferentes condições: com voltagem de $40 \mathrm{~mA}$ e $45 \mathrm{~mA}$. Em seguida, a profundidade de polimerização foi avaliada utilizando-se o penetrômetro. Os resultados obtidos mostraram que a faixa de espectro de luz emitida pelos LEDs (experimental e comercial) foi menor que a apresentada pela luz halógena, sendo que o pico do LED63 foi de $457 \mathrm{~nm}$ e do LuxOMax foi de 466nm. O LuxOMax alcançou a menor profundidade de polimerização dentre os aparelhos testados. Entre os aparelhos LED63 e a luz halógena, não houve diferença estatística nos valores de profundidade encontrados para a cor A2, no entanto, para a cor mais escura (A4), o LED63 demonstrou melhores resultados. Os autores desta forma puderam concluir com este estudo que, uma unidade LED com $8 \mathrm{~mm}$ de diâmetro na ponta emissora de luz é capaz de promover uma profundidade de polimerização estatisticamente melhor para uma resina que contenha a canforoquinona como fotoiniciador quando comparada com uma unidade de luz halógena com ponta de diâmetro similar. No entanto, isto não é conseguido quando resinas contendo outros fotoiniciadores são utilizadas, portanto, os autores sugerem a associação de LEDs com diferentes comprimentos de onda em um mesmo arranjo como uma possibilidade de atingir mais de um fotoiniciador. Outra alternativa seria a padronização de um único fotoiniciador pelos fabricantes de resina composta.

LEONARD et al. ${ }^{40}$, em 2002 , propuseram-se a realizar uma pesquisa para comparar a eficiência de cura de aparelhos de LED comercialmente disponíveis com uma unidade fotoativadora dotada de lâmpada halógena convencional. A 
profundidade de polimerização foi medida por meio da microdureza Knoop em espécimes de $2 \mathrm{~mm}$ de espessura de dois tipos de resina composta, sendo uma de micropartículas e outra, microhíbrida. Os fotopolimerizadores testados foram o ZAP Dual Curing Light, Luma Cure, VersaLux e Optilux 401 quanto a sua densidade de potência e espectro de luz. Neste aspecto, a lâmpada halógena mostrou que na faixa de 450 a 500nm de comprimento de onda, a densidade de potência foi quatro vezes maior que para os aparelhos emissores de diodo (LEDs). Em conseqüência deste fato, as unidades do tipo LED necessitaram de 39 a 61 segundos para polimerizar a resina de micropartículas e de 83 a 121 segundos para a resina microhíbrida, enquanto que a lâmpada halógena precisou de somente 21 e 42 segundos, respectivamente, para polimerizar as resinas compostas. Com este trabalho, os autores supuseram que a primeira geração de unidades de LED requer um considerável maior tempo de exposição que os aparelhos convencionais de luz halógena para polimerizar adequadamente os dois tipos de resina estudados.

No trabalho publicado na literatura científica especializada por DUNN; $\mathrm{BUSH}^{17}$, em 2002, foram testadas duas resinas compostas, sendo uma microhíbrida (Filtek Z250 - 3M/ESPE) e outra de micropartículas (Renamel Cosmedent), utilizando-se para sua polimerização dois aparelhos de lâmpada halógena (Optilux 400 e Optilux 501 - Demetron) e dois aparelhos à base de diodos (LumaCure - LumaLite; Versalux - Centrix). Para avaliar as propriedades físico-mecânicas obtidas com cada tipo de aparelho, as resinas foram submetidas a testes de dureza Knoop, verificando, assim, a profundidade de polimerização 
alcançada. Os autores demonstraram neste estudo que tanto a dureza superficial como a na base dos espécimes de resina apresentou valores maiores quando a fotoativação foi realizada com as unidades de lâmpada halógena, em comparação com as unidades de LED. Desta forma, os autores recomendaram que estudos adicionais deveriam ser realizados para determinar o grau de conversão dos monômeros em polímeros e as propriedades mecânicas do material, antes de recomendar o uso rotineiro destes aparelhos à base de diodos emissores de luz.

HALVORSON; ERICKSON; DAVIDSON ${ }^{29}$, em 2002, com o intuito de averiguar a relação existente entre a extensão de polimerização e a energia de irradiação aplicada durante a polimerização das resinas compostas, realizou um estudo utilizando espectroscopia de infravermelho para avaliar alguns compósitos disponíveis comercialmente. Para isto, foram confeccionados corpos-de-prova de resina (Heliomolar - Vivadent; Silux Plus - 3M/ESPE; Herculite - XRV; Z100 3M/ESPE) que foram fotoativados com o aparelho de lâmpada halógena XL 3000 (3M/ESPE) sob as condições de 30s de tempo de exposição e densidade de potência decrescente e posteriormente, submetidos ao teste de grau de conversão após 5 minutos e 24 horas de sua polimerização. Os resultados mostraram que houve queda gradual na conversão dos monômeros com a diminuição da energia fornecida, sendo que os períodos de 5 minutos e 24 horas demonstraram perfis similares quando à conversão. Também foi observado que houve conversão semelhante nos grupos que receberam doses equivalentes de energia total, evidenciando a relação entre a densidade de potência e o tempo de ativação. 
Com o intuito de comparar dois recentes aparelhos à base de LED com um aparelho de lâmpada halógena convencional, ASMUSSEN; PEUTZFELDT ${ }^{3}$, em 2003, realizaram uma pesquisa com três resinas compostas. As propriedades avaliadas foram resistência flexural e modular, pelo teste em três pontos de curvatura do espécime. A profundidade de polimerização foi avaliada pela remoção do material por raspagem após a ativação, a contração de polimerização pelo método de "bonded-disk" e o grau de conversão por espectroscopia por infravermelho (Fourier). Pelos resultados obtidos, os autores puderam verificar que as propriedades mecânicas das resinas compostas após a fotoativação com LED foram semelhantes ou inferiores às propriedades das resinas fotoativadas com a unidade de lâmpada halógena. No entanto, os autores relatam que embora os aparelhos de LED tenham alcançado valores de resistência flexural e profundidade de polimerização inferiores em relação à fonte de luz halógena, os valores apresentados atenderam às exigências da Organização dos Padrões Internacionais (ISO).

PRICE; FELIX; ANDREOU ${ }^{60}$, em 2003, realizaram um estudo para comparar a segunda geração de unidades fotoativadoras à base de diodos emissores de luz (LEDs) com uma unidade de lâmpada halógena convencional. O aparelho de LED UltraLume 2 (Ultradent) foi testado para polimerizar 10 diferentes resinas compostas pelos tempos de ativação de 20 s e 40 s e teve seu desempenho comparado com o aparelho Optilux 401 (Kerr) quando ativado por 
40s. Para avaliar as propriedades mecânicas alcançadas pelas resinas após polimerizadas com as fontes de luz estudadas, testes de microdureza Knoop foram realizados nas superfícies de topo e base dos espécimes confeccionados para a pesquisa nos períodos de 15 minutos e 24 horas passados da fotoativação. Os resultados encontrados mostraram que após 24 horas, o aparelho de LED utilizado por 20s polimerizou cinco resinas tão bem quanto o de lâmpada halógena ao ser ativado por 40 s, no que diz respeito à propriedade de dureza analisada. Em relação ao tempo de 40s, o LED apresentou uma proporção de $80 \%$ de grau de polimerização para todas as resinas em comparação com o grau atingido pelo aparelho convencional. Isto permitiu aos autores concluírem que, o UltraLume 2, ao ser empregado por 40s para ativação dos compósitos demonstrou desempenho comparável ao produzido pela fonte de luz halógena estudada.

LOPES $^{41}$, em 2003, com o objetivo de avaliar a contração de polimerização e as tensões promovidas pela fotoativação com aparelhos à base de diodo emissor de luz, aparelhos de lâmpada halógena convencional e halógena com modulação da ativação (pulso), comparando seu efeito em resinas compostas de diferentes composições (micropartículas, híbrida, condensável e de ativação química). O autor observou que o sistema químico de ativação produziu os menores valores de contração de polimerização e de tensões. Os resultados encontrados mostraram que a técnica do pulso interrompido reduziu os valores de contração das resinas compostas, quando comparado com as demais técnicas 
testadas (halógena convencional e LED), sendo que o LED demonstrou menor contração de polimerização que a fonte halógena convencional.

Em 2003, SOH; YAP; SIOW ${ }^{70}$, procuraram estudar se a efetividade de polimerização de uma resina composta está associada aos diferentes tipos de fontes de luz e dos modos de ativação. Para isso, utilizaram a resina microhíbrida Filtek Z100 (3M/ESPE) em espécimes de $2 \mathrm{~mm}$ de espessura e dos aparelhos fotoativadores do tipo LED (Elipar FreeLight - 3M/ESPE e GC e-Light - CG) de unidades de lâmpada halógena convencional (Max - Dentsply), de alta densidade de potência (Elipar Trilight - 3M/ESPE) e de altíssima densidade (Astralis 10 Ivoclar/Vivadent). Foram adotadas várias combinações de densidade de potência e tempo de ativação para os diferentes aparelhos. A análise do grau de polimerização foi realizada por meio de testes de microdureza Knoop nas superfícies de topo e base dos espécimes. Os resultados obtidos com os testes mostraram que houve uma diferença significativa entre os valores de dureza encontrados no topo e na base do material, tanto para as diferentes combinações de densidade de energia numa mesma fonte de luz, como entre as fontes de LED e halógena. A maioria das fotoativações com os aparelhos de LED apresentaram resultados inferiores à fonte de luz convencional (controle), exceto para o Elipar FreeLight $\left(400 \mathrm{~mW} / \mathrm{cm}^{2}\right)$ quando utilizado por $40 \mathrm{~s}$, atingindo uma densidade de energia de $16 \mathrm{~J} / \mathrm{cm}^{2}$. Para as unidades de lâmpada halógena de alta densidade, não houve diferença significante em relação à fonte convencional (Max), tendo o Elipar Trilight apresentado valores maiores que esta em algumas condições experimentais. 
Outro trabalho apresentado na literatura diz respeito à pesquisa realizada por CALHEIROS et al. ${ }^{10}$, em 2003, que verificou a relação entre a tensão de contração e o grau de conversão nos compósitos (Filtek Z250; A110; Tetric Ceram e Heliomolar). Para analisar a tensão, espécimes de $2 \mathrm{~mm}$ de resina foram colocados entre bastões de uma máquina de ensaios e sua distância medida por um extensômetro, enquanto que para avaliar o grau de conversão, os autores utilizaram a espectroscopia por infravermelho. Para cada compósito foram constituídos diferentes grupos de acordo com a variação de densidade de energia $\left(4,8 / 13,5 / 27 / 54 / 108 \mathrm{~J} / \mathrm{cm}^{2}\right)$. Os resultados encontrados mostraram que houve uma relação entre o grau de conversão e a densidade de energia e que para os níveis mais elevados de energia, pequenos aumentos no grau de conversão corresponderam a aumento significante na tensão gerada.

DEB; SEHMI ${ }^{16}$, em 2003, conduziram um estudo para investigar o efeito da tecnologia de arco de plasma sobre as propriedades de alguns materiais fotossensíveis quando comparado com a utilização da fonte convencional de lâmpada halógena. Os materiais foram fotoativados pelo tempo de $3 \mathrm{~s}$ com densidade de $1370 \mathrm{~mW} / \mathrm{cm}^{2}$ pelo aparelho Apollo 95E (DMSD) ou pelos tempos de 20s e 40 s com $460 \mathrm{~mW} /{ }^{\mathrm{cm} 2}$ quando expostos à luz halógena Prismetics Lite II (Dentsply). Com os espécimes confeccionados (1,5mm de espessura), testes de dureza Vickers nas superfícies exposta à luz e não-exposta à luz foram realizados para avaliar as propriedades mecânicas dos materiais. Os resultados mostraram 
que na superfície voltada para a fonte de luz, os grupos da luz halógena apresentaram valores significantemente maiores de dureza em comparação ao grupo do arco de plasma. Ao analisar a diferença de valores entre as superfícies dentro dos mesmos grupos, o arco de plasma demonstrou dureza consideravelmente menor na base dos espécimes para três dos quatro materiais testados, o que não ocorreu com os grupos da unidade de lâmpada halógena. Os autores concluíram que o tempo de 3 s para polimerização, utilizado com o arco de plasma, não foi suficiente para atingir ótimas propriedades dos materiais fotoativáveis.

FRANCO; BOSQUIROLI; LOPES ${ }^{25}$, em 2003, realizaram um estudo para determinar a resistência à tração do cimento ionomérico Vitremer (3M/ESPE) em função do tipo de fonte de luz, utilizando um aparelho de luz halógena (XL 2500 3M/ESPE) com densidade de potência de $760 \mathrm{~mW} / \mathrm{cm}^{2}$ e um tipo de LED (Ultraled - Dabi-Atlante) com densidade de $130 \mathrm{~mW} / \mathrm{cm}^{2}$. Os incrementos de material polimerizado eram de $1 \mathrm{~mm}$ de espessura e o tempo de exposição à luz foi de 40 segundos. Encontraram neste trabalho que os valores de resistência à tração apresentados pelo material testado foi de $5,98 \mathrm{Kgf}$ quando polimerizados com luz halógena e 5,50Kgf quando a ativação do ionômero havia sido realizada com LED. Frente a isso, os autores sugeriram que o LED de baixa intensidade de luz foi eficaz na polimerização do cimento de ionômero de vidro modificado por resina, assemelhando-se ao sistema de luz halógena, constituindo-se, desta forma, em uma alternativa viável para a polimerização. 
BOTTINO et al. ${ }^{8}$, em 2003, realizaram um estudo com o objetivo de avaliar a efetividade de polimerização de um aparelho à base de LED através da análise da microinfiltração marginal quando comparado com a fotoativação convencional e gradual. Para esta pesquisa, os autores utilizaram terceiros molares humanos hígidos, nos quais foram preparadas cavidades classe $\mathrm{V}$ no terço cervical das faces vestibular e lingual com ponta diamantada e alta-rotação. As cavidades receberam o tratamento adesivo e foram preenchidas com resina composta Palfique Estelite (Tokuyama), sendo em seguida, separadas em grupos para serem fotopolimerizadas com os aparelhos em estudo: Halógena convencional Curing Light XL300 (3M/ESPE) por 20s; Halógena gradual Soft-Start (Degussa) por 20s e o LED Ultrablue III (DMC) por 40s. Os dentes foram termociclados e imersos em nitrato de prata para posteriormente serem seccionados e analisados quanto ao escore de microinfiltração. Os resultados obtidos mostraram que não houve diferença significante na infiltração marginal das restaurações entre os aparelhos testados, levando os autores a perceber que o aparelho de LED testado foi tão eficaz na polimerização da resina composta estudada quanto os aparelhos de lâmpada halógena, fato este comprovado por meio da análise da microinfiltração em restaurações de classe V.

BOSQUIROLI ${ }^{7}$, em 2003, realizou um estudo com o objetivo de avaliar a resistência à tração de uma resina composta (Filtek Z250 - 3M/ESPE) fotopolimerizada por diferentes fontes de luz e por diferentes tempos de ativação. 
Utilizando-se de um aparelho de luz halógena com densidade de potência de $670 \mathrm{~mW} / \mathrm{cm}^{2}$ (Curing Light 2500 - 3M/ESPE) e outro do tipo LED com densidade de $130 \mathrm{~mW} / \mathrm{cm}^{2}$ (Ultraled - DabiAtlante), os espécimes de resina confeccionados, foram fotoativados pelos tempos de 20 s e 40 s (cor A1) e de 40 s e 80 s (cor A4). Com os resultados obtidos na pesquisa, a autora pode observar que o aparelho fotopolimerizador LED foi tão efetivo na polimerização da resina composta quanto o aparelho de lâmpada halógena. O aumento do tempo de ativação não exerceu influência na resistência à tração do material e também foi verificado que a resistência à tração para a resina Filtek Z250 nas cores A1 e A4 não foi afetada pela variação do tempo de ativação, tão pouco pelas fontes de luz estudadas.

FERRAREZI; CEFALY, NAVARRO ${ }^{22}$, em 2003, objetivaram comparara a efetividade de polimerização de dois aparelhos fotoativadores, sendo um de lâmpada halógena (Curing Light 2500 - 3M/ESPE) e o outro de LED (Ultraled Dabi/Atlante), na polimerização de alguns materiais resinosos (Z100, Dyract e Denifite). Para isto, confeccionaram 20 espécimes para cada material estudado e os mesmos foram fotoativados com os aparelhos pelos tempos de 40 s e 60 s de exposição. Em seguida, os espécimes foram submetidos ao teste de microdureza Knoop, sendo que, com os resultados obtidos, pode-se notar que não houve diferença entre as fontes de luz testadas para superfície da Z100 e do Dyract, enquanto que para a Definite, os valores encontrados foram significantemente menores quando polimerizada com o Ultraled. Na região de base dos espécimes, observou-se que a microdureza foi significantemente menor quando todos os 
materiais foram polimerizados com o LED. Nenhuma diferença estatística foi notada entre os valores na superfície e na base dos grupos da resina Z100 e do Dyract quando ativados com o aparelho de luz halógena; entretanto, a mesma similaridade não pode ser verificada para a Definite e o Dyract nos grupos fotopolimerizados com o Ultraled. Os autores concluíram, desta forma, que o LED não foi capaz de produzir a mesma microdureza para os materiais resinosos do que o aparelho convencional de lâmpada halógena.

RIBEIRO et al. ${ }^{61}$, em 2003, realizaram um estudo para verificar a influência de quatro aparelhos de fotoativação sobre a microdureza Vickers de uma resina composta Filtek Z250 na cor A2 (3M/ESPE). Foram confeccionados espécimes cilíndricos de dimensões de $5 \mathrm{~mm}$ de diâmetro por $2 \mathrm{~mm}$ de altura, que foram fotoativados por 40 s e armazenados em recipientes escuros por $24 \mathrm{hs}$. Os aparelhos testados foram: Optilux (Demetron), Ultraled (Dabi/Atlante), Ultralume LED 2 (Ultradent) e Elipar FreeLight (3M/ESPE). Os corpos-de-prova foram submetidos aos testes de microdureza nas superfícies de topo e base e os dados obtidos foram analisados pelos autores que verificaram que os aparelhos de LED de $2^{a}$ geração apresentaram maiores valores de dureza em todas as condições experimentais estudadas quando comparados aos demais aparelhos, porém não houve diferença entre si. O grupo que foi fotoativado com a unidade de lâmpada halógena mostrou resultados intermediários e o grupo do Ultraled (LED de $1^{\text {a }}$ geração - baixa densidade de potência) obteve os menores valores de microdureza para a resina composta. 
HALVORSON; ERICKSON; DAVIDSON ${ }^{30}$, em 2003, realizaram um estudo visando avaliar algumas variáveis do processo de polimerização como a densidade de potência das fontes de luz, o tempo de exposição e as propriedades de transmissão de luz das resinas compostas. Além disso, foi observada também a relação energia/conversão por meio de espectroscopia por infravermelho (FTIR). Foram utilizadas neste estudo as resinas Herculite XRV e Filtek Z100 na cor A3.5 e o aparelho de Lâmpada halógena XL 3000 para confecção dos espécimes, considerando uma densidade de energia de $18 \mathrm{~J} / \mathrm{cm}^{2}\left(600 \mathrm{~mW} / \mathrm{cm}^{2} \mathrm{x}\right.$ 30s). Os resultados mostraram que, embora ambos materiais tenham sido analisados no mesmo matiz, a resina Z100 apresentou maior profundidade de polimerização em relação a Herculite XRV devido à sua menor radiopacidade que permitiu melhor transmissão da luz pelo material. Observou-se também que a profundidade de polimerização está logaritmicamente relacionada com a energia de ativação e que a reciprocidade entre tempo e irradiância existe. Os autores ainda sugerem que quando o material é fotoativado com arco de plasma ou LED, a conversão atingida pode ser diferente devido ao calor emitido pelo primeiro e a possível melhor eficiência de polimerização do segundo.

PRICE; FELIX; ANDREOU ${ }^{60}$, em 2004, realizaram um estudo para determinar o efeito da distância da fonte de luz à resina composta durante a ativação para fotopolimerização, por meio da avaliação da microdureza do material nas superfícies de topo e base. Para isto fizeram uso de cinco diferentes 
resinas compostas (Heliomolar, Herculite, Esthet-X, Virtuoso Sculpture e Virtuoso Flowable), três unidades fotopolimerizadoras (Optilux 401, Phase II e Sapphire), sendo dois aparelhos de lâmpada halógena e um aparelho de arco de plasma, com distribuição espectral similar, mas diferentes densidades de potência para polimerizar os materiais em diferentes tempos de irradiação. Para representar as distâncias clínicas, os compósitos foram irradiados a $2 \mathrm{~mm}$ e $9 \mathrm{~mm}$ distantes da ponteira-guia da fonte de luz. A microdureza foi medida no topo e na base dos espécimes que possuíam 1,6mm de espessura após 15 minutos e 24 horas da ativação. Os resultados mostraram que, embora se tenha observado um aumento na microdureza dos materiais após $24 \mathrm{~h}$ da irradiação com várias combinações de aparelhos e tempos, o valor de dureza máxima não foi alcançado após este período. Os valores de dureza encontrados na base foram significantemente menores que os $80 \%$ recomendados em relação à dureza da superfície de topo para as resinas Heliomolar, Virtuoso Sculpture e Virtuoso Flowable. Isto fez com que os autores afirmassem que, dependendo da resina composta utilizada, o cirurgião-dentista pode erroneamente acreditar que a base da restauração está polimerizada adequadamente se o topo da mesma parecer com dureza satisfatória. Foi verificado também neste estudo, que os efeitos do distanciamento ponteira-resina não foram semelhantes para todas as fontes de luz. Quando a distância foi de $9 \mathrm{~mm}$, a microdureza da base dos espécimes foi afetada nos grupos em que se utilizou o aparelho de luz halógena Phase II, pois a densidade de potência desta unidade decresceu de $1129 \mathrm{~mW} / \mathrm{cm}^{2}$ (densidade de saída do aparelho) para $243 \mathrm{~mW} / \mathrm{cm}^{2}$, e o arco de plasma apresentou os melhores resultados. No entanto, ao se empregar uma distância de $2 \mathrm{~mm}$, o arco de plasma 
ativado por 3s foi a combinação aparelho/tempo que apresentou os piores resultados de microdureza, por não atingir uma densidade de energia suficiente para polimerizar a resina composta. Desta forma, os autores concluíram que a escolha do compósito e da distância para irradiação tem efeito significante quando se compara a habilidade de cura dos diferentes fotopolimerizadores; e que, para se conseguir uma microdureza satisfatória da resina composta utilizando aparelhos com espectros similares, mas diferentes densidades de potência, os tempos de ativação devem ser ajustados para fornecer densidades de energia similares para todos os materiais.

Em 2004, SOH; YAP ${ }^{71}$, investigaram a influência dos modos de fotopolimerização na densidade de ligações cruzadas nas resinas compostas. A resina Filtek Z100 (3M/ESPE) na cor A2 e a unidade fotopolimerizadora VIP (BISCO) foram selecionados para tal estudo. Entre as várias possibilidades de combinações de tempo de ativação e intensidade de luz transmitida pelo aparelho, foram avaliados quatro diferentes modos de cura: controle, com intensidade contínua de $400 \mathrm{~mW} / \mathrm{cm}^{2}$; Pulso delay, com intensidade inicial de 300 $\mathrm{mW} / \mathrm{cm}^{2}$ por 10 segundos, espera de 3 minutos e $500 \mathrm{~mW} / \mathrm{cm}^{2}$ finais por 30 segundos; Soft-start, em que a intensidade inicial era de $200 \mathrm{~mW} / \mathrm{cm}^{2}$ por $20 \mathrm{~s}$ e posteriormente ativação por mais 20 s com potência de $600 \mathrm{~mW} / \mathrm{cm}^{2}$; e por fim, a ativação por pulso, com $400 \mathrm{~mW} / \mathrm{cm}^{2}$ nos 20 s iniciais, espera de 20 s e $400 \mathrm{~mW} / \mathrm{cm}^{2}$ por mais 20 s finais. O grau de ligações cruzadas de polímeros foi avaliado tanto direta como indiretamente pela medida da temperatura transmitida pelo vidro e microdureza após a armazenagem em etanol. Para o teste direto, os 
espécimes de resina composta foram confeccionados com espessura de $1 \mathrm{~mm}$ e diâmetro de $5 \mathrm{~mm}$, fotopolimerizados de acordo com o protocolo da pesquisa e mantidos em local seco e escuro por 24 horas a $25^{\circ} \mathrm{C}$. Os valores de temperatura de transmissão pelo vidro foram então determinados utilizando-se da calorimetria diferencial. Para o método indireto de obtenção do grau de ligações cruzadas, outros espécimes foram confeccionados, sendo estes com as dimensões de $2 \mathrm{~mm}$ de espessura e $3 \mathrm{~mm}$ de comprimento. Os mesmos foram fotopolimerizados, armazenados a $37^{\circ} \mathrm{C}$ nas primeiras 24 horas em local seco e testados quanto à sua dureza. Após os testes, foram novamente armazenados, sendo colocados em solução de etanol/água a $75 \%$ em temperatura de $37^{\circ} \mathrm{C}$ por 24 horas e a microdureza foi determinada. Os resultados mostraram que a densidade de ligações cruzadas avaliada por meio da calorimetria apresentaram valores maiores para a técnica convencional, seguida da de pulso, posteriormente do softstart e por fim a técnica do pulso delay. Em relação a microdureza, os valores encontrados para a técnica convencional, pulso delay e soft-start foram significantemente superiores aos da técnica do pulso interrompido. Após a estocagem em solução etanol/água, os valores mostraram que os espécimes polimerizados com o pulso delay tiveram susceptibilidade maior no amolecimento que os espécimes do grupo do pulso interrompido. Nenhuma outra diferença significante foi observada nas ligações cruzadas entre os vários modos de ativação. Desta forma, concluiu-se que a densidade de ligações cruzadas e dependente do modo de fotopolimerização e que comparando os modos estudados, o pulso delay resultou em estrutura polimérica linear com menos ligações cruzadas que as outras técnicas empregadas no estudo. 
TSAI; MEYERS; WALSH ${ }^{76}$, em 2004, avaliaram a profundidade de polimerização e a microdureza superficial da resina composta Filtek Z250 (3M/ESPE) polimerizada por três aparelhos do tipo LED comercialmente disponíveis (E-Light - GC; Elipar Freelight - 3M/ESPE; 475H - RF), um aparelho de alta densidade de potência do tipo halógena (Optilux 501 - Kerr) e um aparelho de lâmpada halógena convencional (Sirona - S1). A profundidade de cura após 40s de exposição às fontes de luz foi determinada em espécimes de $10 \mathrm{~mm}$ de espessura pela microdureza Vickers a cada $1 \mathrm{~mm}$ da extensão da resina composta. As unidades de luz halógena apresentaram os melhores resultados de dureza. Já os aparelhos de LED mostraram valores de dureza similares entre si, embora inferiores aos halógenos, mas estes resultados foram considerados superiores aos valores mínimos de profundidade de polimerização preconizados pela ISO, com exceção do E-Light para a cor B1. Observou-se que a dureza superficial não foi estatisticamente diferente entre LED e halógena, entretanto, conforme a dureza era medida num ponto mais distante do topo do espécime, esta propriedade diminuiu mais rapidamente para as unidades de LED quando comparadas com as fontes de luz halógena, especialmente em profundidades além de $3 \mathrm{~mm}$. Com isto, os autores concluíram que os aparelhos de LED estudados permitem grau de polimerização adequado para as espessuras de resina composta recomendadas para uso da técnica incremental ( $2 \mathrm{~mm}$ ou menos) e que para espessuras além desta, seu desempenho não mais equivale ao dos aparelhos de luz halógena convencional e de alta potência. 
ASENJO-MARTINEZ², em 2004, avaliou o desgaste e a rugosidade superficial da resina composta Filtek Z250 (3M/ESPE), após escovação simulada, em função de diferentes fontes de luz (halógena - VIP/BISCO e LED - Ultrablue IS/DMC). Para a polimerização do compósito, o autor padronizou o tempo de exposição em 20s para todos os grupos, variando apenas a densidade de potência (300 e $600 \mathrm{~mW} / \mathrm{cm}^{2}$ ). Foi observado que a fonte de luz halógena proporcionou melhor comportamento físico-mecânico da resina composta avaliada em comparação à fonte de luz LED com mesma energia de ativação.

TRUJILLO; NEWMAN; STANSBURY ${ }^{74}$, em 2004, conduziram um estudo para determinar o efeito do aumento da temperatura externa na cinética da polimerização e na conversão monomérica de algumas resinas compostas disponíveis comercialmente. Foram utilizados aparelhos de lâmpada halógena (QHL 75), de LED (Elipar FreeLight) e de arco de plasma (PAC 1000) e as resinas compostas selecionadas foram uma híbrida (Herculite XRV), uma de micropartículas (Filtek A110) e uma condensável (Surefil). Espécimes com espessura de $1,25 \mathrm{~mm}$ foram confeccionados para avaliação em espectroscopia por infravermelho, variando-se a temperatura de $23^{\circ} \mathrm{C}$ a $70^{\circ} \mathrm{C}$. Considerando um aquecimento moderado que atingiu a temperatura de $54,5^{\circ} \mathrm{C}$ durante e fotoativação, observou-se que os resultados obtidos nos valores de conversão final foram significantemente maiores nesta situação que quando a ativação foi realizada à temperatura ambiente. Notou-se que o tempo requerido para que a conversão fosse máxima foi reduzido em $80-90 \%$ quando se utilizou alta 
temperatura e não a temperatura ambiente. Assim, os autores concluem com este trabalho que o aumento da temperatura influencia na polimerização do material, aumentando o grau de conversão e, conseqüentemente, as propriedades mecânicas da resina composta.

BALA; ÖLMEZ; KALAYCI ${ }^{5}$, em 2005, avaliaram a profundidade de polimerização de algumas resinas compostas polimerizadas com aparelhos de lâmpada halógena e diodos emissores de luz de $2^{a}$ geração. Utilizando-se de espécimes com dimensões de $6 \mathrm{~mm}$ de diâmetro e $2 \mathrm{~mm}$ de espessura, confeccionados com resinas híbridas (Esthet-X e Filtek Z250), resinas compactáveis (Filtek P60, Prodigy, Surefil, Solitaire) e a resina Admira. Os materiais foram fotoativados por 40 s com os aparelhos Hilux Ultra Plus $\left(600 \mathrm{~mW} / \mathrm{cm}^{2}\right)$ e o LED Elipar Free Light $\left(400 \mathrm{~mW} / \mathrm{cm}^{2}\right)$ e, em seguida, submetidos ao teste de profundidade de polimerização com espectroscopia por infravermelho. Os resultados deste trabalho mostraram que o LED, de forma geral, alcançou melhores extensões de material polimerizado quando comparado com o aparelho convencional, sendo que, seu maior valor obtido de $61 \%$ de polimerização e o da unidade de lâmpada halógena de 55,6\%. Desta forma, os autores concluíram que a tecnologia LED com diodos de alta densidade de potência apresenta vantagens em relação à tecnologia baseada na lâmpada halógena, mesmo quando sua densidade total é menor que desta e, isto ocorre devido à maior concentração da luz emitida na região espectral de interesse para a polimerização dos materiais resinosos. 
3. Proposição 


\section{3 - PROPOSIÇÃo}

O presente estudo teve por objetivo avaliar, comparativamente, a influência de fontes de luz visível, a base de LED e de lâmpada halógena, na resistência intrínseca de coesão da resina composta Filtek Z250, com variação da espessura dos incrementos, por meio do teste de tração axial, assim como, analisar a microdureza na interface correspondente à área de união do material, quando da ativação com diferentes densidades de potência e tempos de exposição. 


\section{Material e Métodos}

\section{1 - Material}

Foram selecionadas três unidades fotoativadoras para realização da presente pesquisa. Utilizou-se o aparelho convencional Curing Light 2500 - CL (3M/ESPE, número de série 3017518$)$ com densidade de potência de $670 \mathrm{~mW} / \mathrm{cm}^{2}$ (Figura 1A), o qual possuía em sua constituição lâmpada halógena de $75 \mathrm{~W}$, com comprimento de onda entre 400 e $500 \mathrm{~nm}^{\star}$ e diâmetro de $8 \mathrm{~mm}$ na porção terminal da ponteira de fibra óptica. Também foram utilizados dois aparelhos de diodo emissor de luz (LED) de densidades de potência diferentes, Ultraled - DabiAtlante - UTL - (lote 4505H000/6 n.001112) com densidade de luz $130 \mathrm{~mW} / \mathrm{cm}^{2}$ (Figura 1B) e Ultrablue IS - DMC ( $n^{\circ}$ de série 0144) com densidades de 300 $\mathrm{mW} / \mathrm{cm}^{2}$ - UB3 - e $600 \mathrm{~mW} / \mathrm{cm}^{2}$ - UB6 - (Figura 1C). As especificações desses aparelhos encontram-se na Tabela 1. A densidade de potência foi verificada por um radiômetro comercial (Curing Radiometer Model 100 P/N - 10503/Demetron Research Corp.), imediatamente antes do uso dos aparelhos para a fotopolimerização, com o objetivo de verificar a irradiação de saída dos aparelhos para alcançar uma padronização e um melhor controle do experimento.

\footnotetext{
* Informações do fabricante
} 


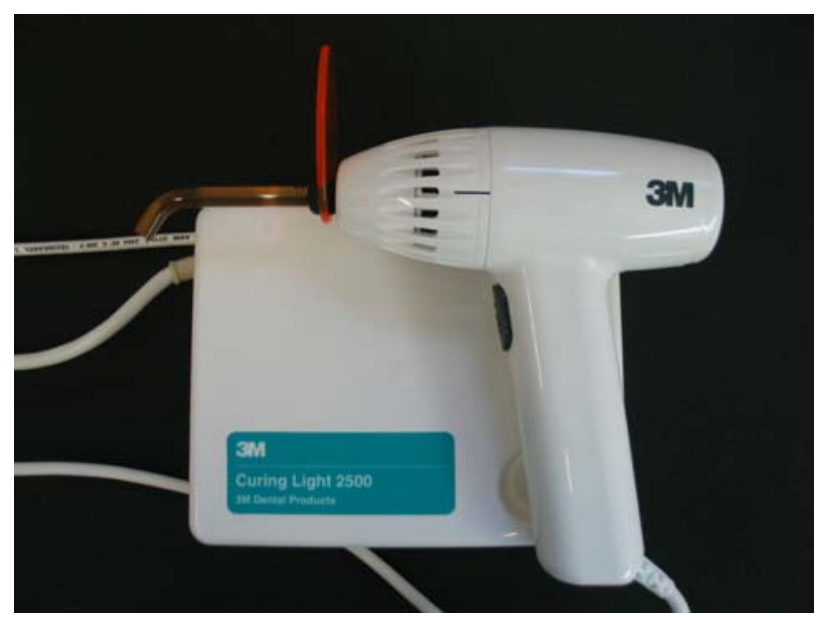

Figura 1A - Curing light 2500- 3M/ESPE

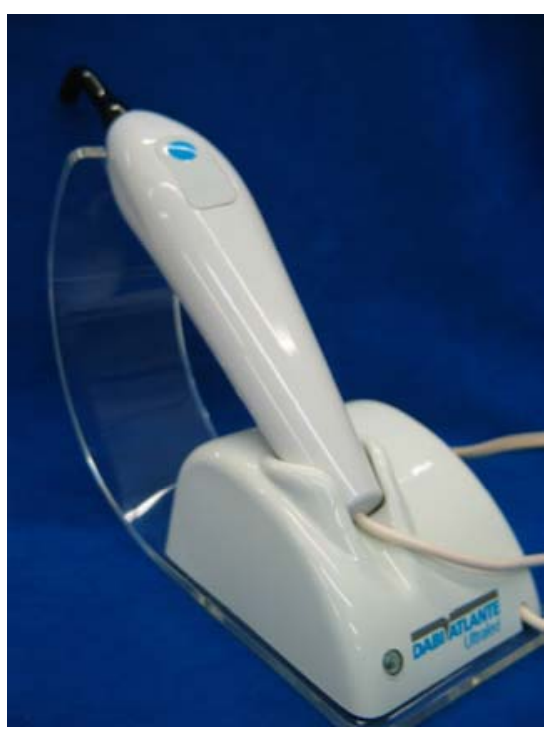

Figura 1B - Ultraled-Dabi-Atlante

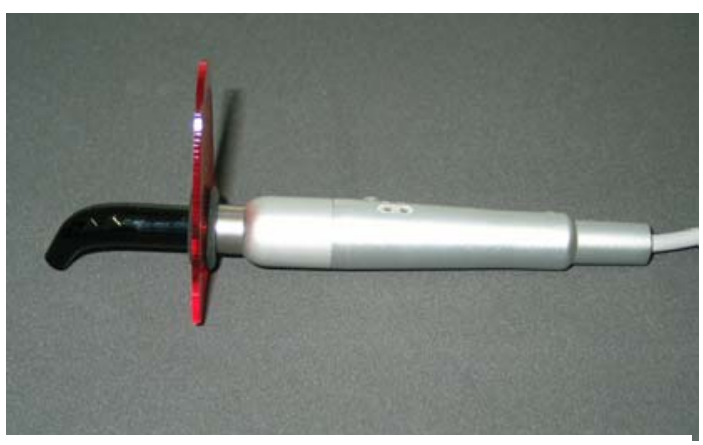

Figura 1C - Ultrablue - DMC 
TABELA 1 - Unidades de fotopolimerização

UNIDADE

Curing Light 2500

Ultraled

Ultrablue

FABRICANTE

3M/ESPE

Dabi Atlante

DMC

\begin{tabular}{cccc}
\hline ABREVIATURA & CL & UTL & UB3 - UB6 \\
\hline $\begin{array}{c}\text { FONTE DE LUZ } \\
\text { DIÂMETRO GUIA DE } \\
\text { LUZ }\end{array}$ & Halógena & LED & LED \\
\hline $\begin{array}{c}\text { FREQÜÊNCIA (Hz) } \\
\text { POTÊNCIA (W) }\end{array}$ & $50 / 60$ & $8 \mathrm{~mm}$ & $7 \mathrm{~mm}$ \\
\hline $\begin{array}{c}\text { COMPRIMENTO DE } \\
\text { ONDA (nm) }\end{array}$ & $700-500$ & $50 / 60$ & 60 \\
\hline $\begin{array}{c}\text { DENSIDADE DE } \\
\text { POTÊNCIA (mW/cm }{ }^{2} \text { ) }\end{array}$ & 670 & $460-480$ & $460-480$ \\
\hline
\end{tabular}

Utilizou-se a resina composta Filtek Z250 - 3M/ESPE (Figura 2), definida pelo fabricante como um compósito polimerizável por luz e radiopaco, desenvolvida para restaurações de dentes anteriores e posteriores. A composição química, tempo de ativação preconizado pelo fabricante e demais informações sobre o produto encontram-se na Tabela 2. A cor selecionada foi somente A1, uma vez que foi comprovado por BOSQUIROLI (2003) ${ }^{7}$ que o fator cor não implica em diferenças significantes nos valores de resistência à tração para a resina composta estudada. 
Tabela 2 - Características das Resinas compostas usadas.

\begin{tabular}{ccccccc}
\hline *Produto & Cor & No lote & Pol seg & Carga & $\begin{array}{c}\text { \% vol } \\
\text { Tamanho médio } \\
\text { partícula( } \boldsymbol{\mu m})\end{array}$ \\
\hline $\begin{array}{c}\text { Filtek Z 250 - } \\
\text { 3M/ESPE }\end{array}$ & A1 & 4PE & 20s & Zirc/Síl & 60 & 0,19 a 3,3 \\
\hline
\end{tabular}

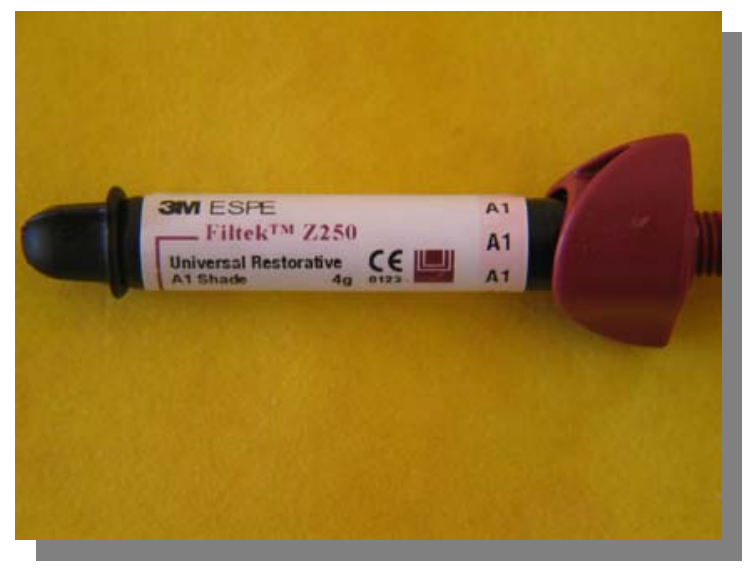

Figura 2 - Resina composta Filtek Z250 - 3M/ESPE.

\section{2 - Preparo dos espécimes para os testes de resistência à tração}

Foram compostos vinte e quatro (24) grupos com 10 espécimes cada, sendo seis (6) grupos fotoativados com aparelho de lâmpada halógena (CL), seis (6) com aparelho de LED de menor densidade de potência (UTL), seis (6) com LED de média densidade (Ultrablue IS $300 \mathrm{~mW} / \mathrm{cm}^{2}$ - UB3) e os outros seis (6) com LED regulado na maior densidade (Ultrablue IS $600 \mathrm{~mW} / \mathrm{cm}^{2}$ - UB6). Com o objetivo de avaliar a influência do tempo de polimerização na resistência à tração para os aparelhos, realizou-se o teste nos tempos de 20s, 40s e 60s. Para verificar a influência da espessura de material, foram utilizados incrementos de 1 e $2 \mathrm{~mm}$. Na 
Tabela 3 encontra-se a distribuição dos espécimes nos diferentes grupos experimentais.

Tabela 3 - Distribuição dos espécimes em grupos.

\begin{tabular}{|c|c|c|c|c|}
\hline \multirow{2}{*}{$\frac{\text { GRUPOS }}{\text { G1 }}$} & \multicolumn{4}{|c|}{ Fonte de luz + Espessura + Tempo de ativação + Densidade de Energia } \\
\hline & $\mathrm{CL}$ & $1 \mathrm{~mm}$ & $20 \mathrm{~s}$ & $13,4 \mathrm{~J} / \mathrm{cm}^{2}$ \\
\hline G2 & $\mathrm{CL}$ & $1 \mathrm{~mm}$ & $40 \mathrm{~s}$ & $26,8 \mathrm{~J} / \mathrm{cm}^{2}$ \\
\hline G3 & CL & $1 \mathrm{~mm}$ & $60 \mathrm{~s}$ & $40,2 \mathrm{~J} / \mathrm{cm}^{2}$ \\
\hline G4 & $C L$ & $2 \mathrm{~mm}$ & $20 \mathrm{~s}$ & $13,4 \mathrm{~J} / \mathrm{cm}^{2}$ \\
\hline G5 & $C L$ & $2 \mathrm{~mm}$ & $40 \mathrm{~s}$ & $26,8 \mathrm{~J} / \mathrm{cm}^{2}$ \\
\hline G6 & CL & $2 \mathrm{~mm}$ & $60 \mathrm{~s}$ & $40,2 \mathrm{~J} / \mathrm{cm}^{2}$ \\
\hline G7 & UTL & $1 \mathrm{~mm}$ & $20 \mathrm{~s}$ & $2,6 \mathrm{~J} / \mathrm{cm}^{2}$ \\
\hline G8 & UTL & $1 \mathrm{~mm}$ & $40 s$ & $5,2 \mathrm{~J} / \mathrm{cm}^{2}$ \\
\hline G9 & UTL & $1 \mathrm{~mm}$ & $60 \mathrm{~s}$ & $7,8 \mathrm{~J} / \mathrm{cm}^{2}$ \\
\hline G10 & UTL & $2 \mathrm{~mm}$ & $20 \mathrm{~s}$ & $2,6 \mathrm{~J} / \mathrm{cm}^{2}$ \\
\hline G11 & UTL & $2 \mathrm{~mm}$ & $40 s$ & $5,2 \mathrm{~J} / \mathrm{cm}^{2}$ \\
\hline G12 & UTL & $2 \mathrm{~mm}$ & $60 \mathrm{~s}$ & $7,8 \mathrm{~J} / \mathrm{cm}^{2}$ \\
\hline $\mathrm{G} 13$ & UB3 & $1 \mathrm{~mm}$ & $20 s$ & $6 \mathrm{~J} / \mathrm{cm}^{2}$ \\
\hline G14 & UB3 & $1 \mathrm{~mm}$ & $40 \mathrm{~s}$ & $12 \mathrm{~J} / \mathrm{cm}^{2}$ \\
\hline G15 & UB3 & $1 \mathrm{~mm}$ & $60 \mathrm{~s}$ & $18 \mathrm{~J} / \mathrm{cm}^{2}$ \\
\hline G16 & UB3 & $2 \mathrm{~mm}$ & $20 \mathrm{~s}$ & $6 \mathrm{~J} / \mathrm{cm}^{2}$ \\
\hline G17 & UB3 & $2 \mathrm{~mm}$ & $40 \mathrm{~s}$ & $12 \mathrm{~J} / \mathrm{cm}^{2}$ \\
\hline G18 & UB3 & $2 \mathrm{~mm}$ & $60 \mathrm{~s}$ & $18 \mathrm{~J} / \mathrm{cm}^{2}$ \\
\hline G19 & UB6 & $1 \mathrm{~mm}$ & $20 \mathrm{~s}$ & $12 \mathrm{~J} / \mathrm{cm}^{2}$ \\
\hline G20 & UB6 & $1 \mathrm{~mm}$ & $40 \mathrm{~s}$ & $24 \mathrm{~J} / \mathrm{cm}^{2}$ \\
\hline G21 & UB6 & $1 \mathrm{~mm}$ & $60 s$ & $36 \mathrm{~J} / \mathrm{cm}^{2}$ \\
\hline $\mathrm{G} 22$ & UB6 & $2 \mathrm{~mm}$ & $20 s$ & $12 \mathrm{~J} / \mathrm{cm}^{2}$ \\
\hline G23 & UB6 & $2 \mathrm{~mm}$ & $40 \mathrm{~s}$ & $24 \mathrm{~J} / \mathrm{cm}^{2}$ \\
\hline G24 & UB6 & $2 \mathrm{~mm}$ & $60 \mathrm{~s}$ & $36 \mathrm{~J} / \mathrm{cm}^{2}$ \\
\hline
\end{tabular}


Para confecção dos espécimes, utilizou-se um conjunto de matrizes de aço inoxidável composto de duas partes semelhantes, sendo que cada parte apresentava um orifício central cônico com 5,0mm no diâmetro menor e 8,0mm no diâmetro maior, e 1,0mm ou 2,0 mm de espessura, conforme o grupo experimental (Figura 3A). As duas partes das matrizes foram posicionadas uma sobre a outra pela base menor do orifício central e adaptadas a um dispositivo metálico com dimensão exata para acomodar o conjunto de matrizes. Internamente a esse dispositivo foram adaptadas uma base de acrílico, juntamente com uma tira de poliéster, para evitar a aderência da resina (Figura 3B). A resina composta Filtek Z250 foi, então, inserida (Figura 3C) em incremento único, com auxílio de espátula (Thompson $\mathrm{n}^{\circ} 4$ ), adaptando-se, em seguida, uma tira de poliéster sobre a superfície da resina para regularizar a espessura do material e permitir o contato direto com a ponteira do aparelho fotopolimerizador. Realizou-se a ativação conforme os tempos determinados para os diferentes grupos. Para permitir adequada polimerização dos dois segmentos do conjunto de matrizes, a ativação foi realizada em duas etapas. Desta forma, cada segmento recebeu metade do tempo estabelecido para cada espécime (Figura 3D), ou seja, para o tempo total de 20 segundos utilizou-se 10 segundos em cada superfície exposta do material e assim sucessivamente para os tempos de 40 s e 60 s. 
A

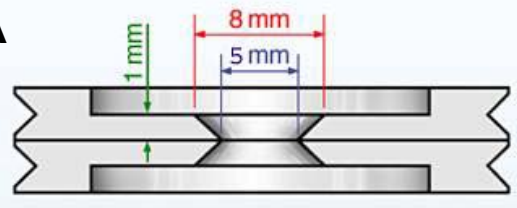

B
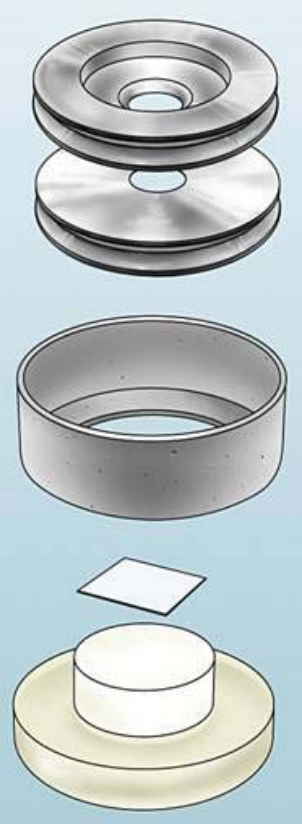

C

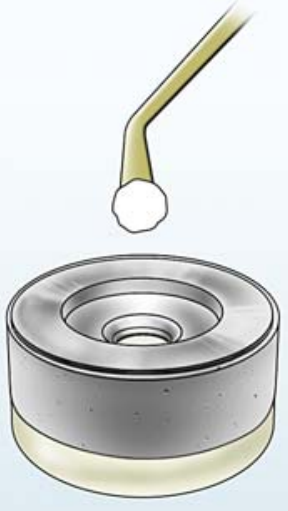

D
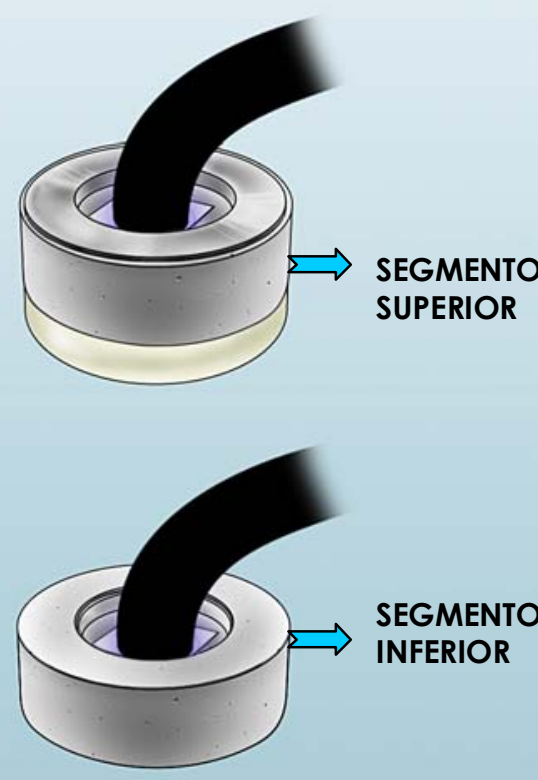

SEGMENTO INFERIOR

Figura 3 - A: Corte transversal do conjunto de matrizes posicionadas. B: Esquema do posicionamento das matrizes + dispositivo para acomodar 0 conjunto de matrizes + tira de poliéster + base de acrílico. C: Inserção da resina composta. D: Fotopolimerização em duas etapas; primeira etapa no segmento superior e segunda etapa, após remoção da base de acrílico e inversão do conjunto, no segmento inferior. 


\section{3 - Testes de resistência à tração}

Os espécimes de cada grupo foram numerados de um a dez, aguardandose o tempo de dez minutos após a polimerização, para que o conjunto matriz/espécime fosse levado à Máquina Universal de Ensaios Kratos (Modelo K2000MP, n de série - M970201 com capacidade de 2000 Kgf; Software TRACOMP - W95 - TRCV36) - Figura 4. Para possibilitar o teste de tração, esse conjunto foi acoplado a um dispositivo de fixação do espécime (Figura 5) e, em seguida, conectado à carga $\mathrm{n}^{\circ} 2$ da máquina de ensaios (Figura 6). $\mathrm{O}$ teste foi realizado a uma velocidade de $0,5 \mathrm{~mm} / \mathrm{min}$ até o momento da fratura do espécime (Figura 7), registrando-se o valor requerido para ruptura em $\mathrm{Kgf} / \mathrm{cm}^{2}$, sendo que esse valor foi, posteriormente, convertido para a unidade de Mega Pascal (MPa).

$$
\mathrm{Kgf} / \mathrm{cm}^{2} \times 0,0981=\mathrm{MPa}
$$

Fórmula de conversão de unidades (kilograma-força para Mega Pascal) 




Figura 4 - Máquina Universal de Ensaios - Kratos

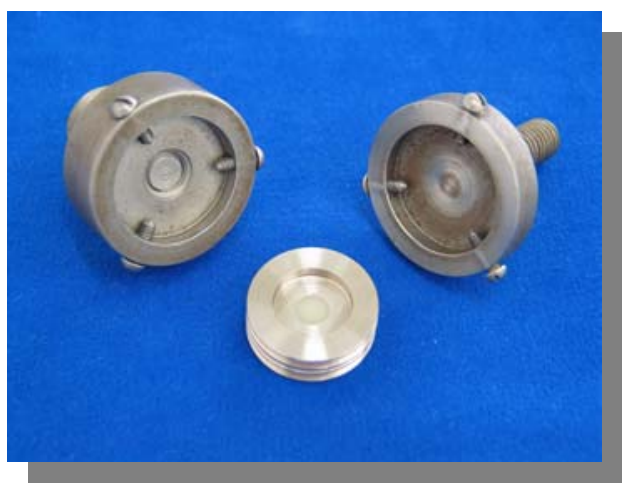

Figura 5 - Dispositivos de adaptação das matrizes.

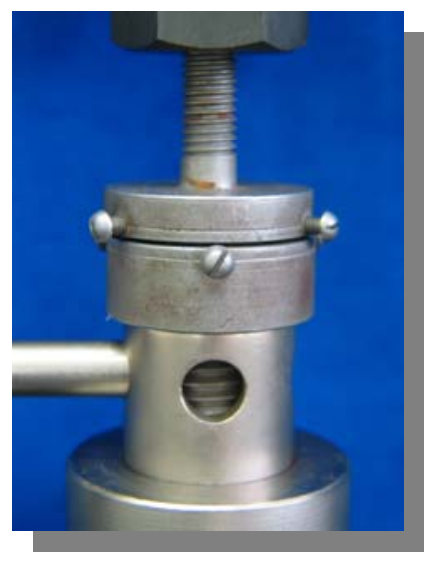

Figura 6 - Acoplamento do espécime na Máquina Universal de Ensaios.

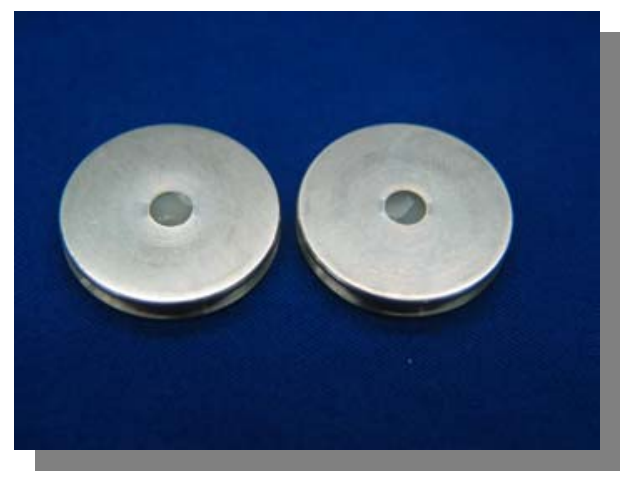

Figura 7 - Aspecto da fratura do material após teste de tração. 


\section{4 - Preparo dos espécimes para teste de microdureza}

Com o intuito de avaliar as propriedades mecânicas do material restaurador na interface de fratura ocasionada pela força aplicada durante o teste de tração, decidiu-se medir a microdureza da resina composta na interface correspondente à área de união, por ser esta a região que se apresentou mais distante da fonte de luz quando polimerizada.

Para a realização do teste de microdureza, os espécimes de resina composta foram confeccionados utilizando-se as mesmas matrizes empregadas para o teste de tração, de acordo com a descrição anterior. Um diferencial na obtenção dos espécimes foi a interposição de uma tira de poliéster entre as porções superior e inferior da matriz, uma vez que havia a necessidade de se obter uma superfície com lisura adequada para realizar as avaliações junto ao microdurômetro. Dessa forma, foram obtidos 5 espécimes (Figura 8) para cada condição experimental, o que somou um total de 120 espécimes.

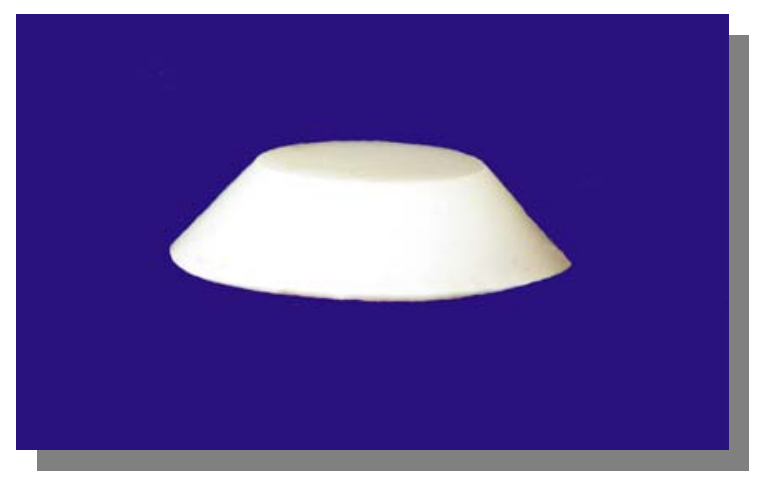

Figura 8 - Espécime para teste de microdureza após ser removido da matriz. 


\section{5 - Teste de microdureza}

A avaliação da microdureza Knoop do material estudado nesta pesquisa foi realizada utilizando-se o microdurômetro Shimadzu HMV-2 (344-04152-02; nI63034100673 - Shimadzu Corporation, Kyoto, Japan), acoplado a um software para análise das imagens, Cans - Win (NewAge Industrie, USA) - Figura 9

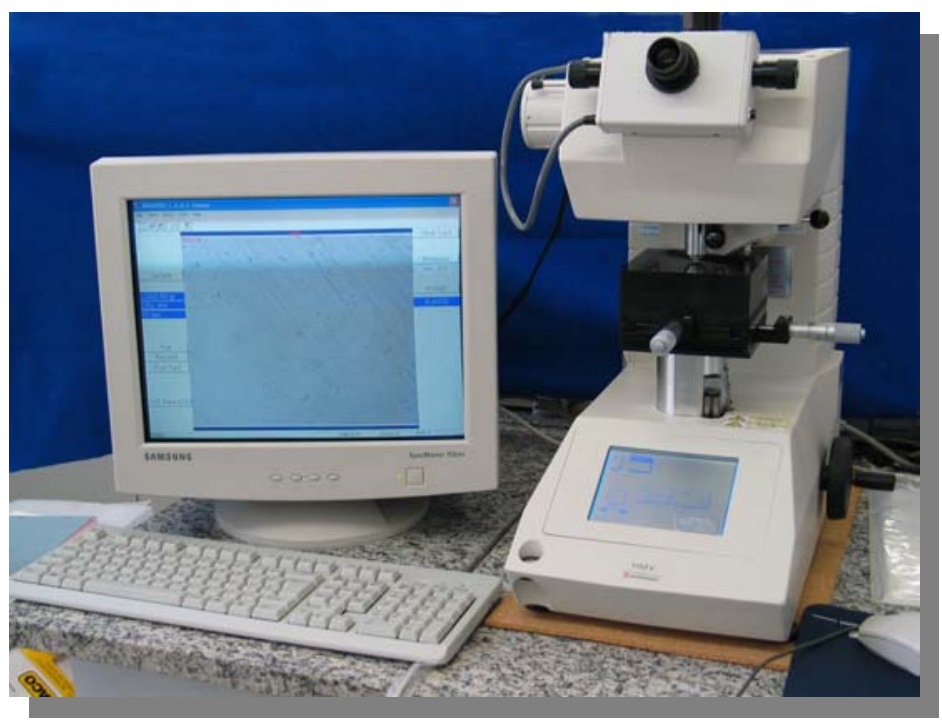

\section{Figura 9 - Microdurômetro Shimadzu HMV-2}

Foram feitas 5 impressões (marcações) nos espécimes (Figura 10), dispostas da seguinte forma: inicialmente uma marcação na região central era realizada na superfície do material; as demais marcações eram obtidas nos 4 pólos do espécime (norte, sul, leste e oeste), com uma distância de aproximadamente $100 \mu \mathrm{m}$ do centro, e a área escolhida para realizar tais impressões estava no mínimo a $1000 \mu \mathrm{m}$ da lateral do bloco para se evitar trincas. Selecionou-se o penetrador tipo Knoop, o qual é mais indicado para esse tipo de 
material odontológico pelas suas características mais plásticas, sendo a carga estática determinada em $50 \mathrm{~g}$ por 30 segundos.

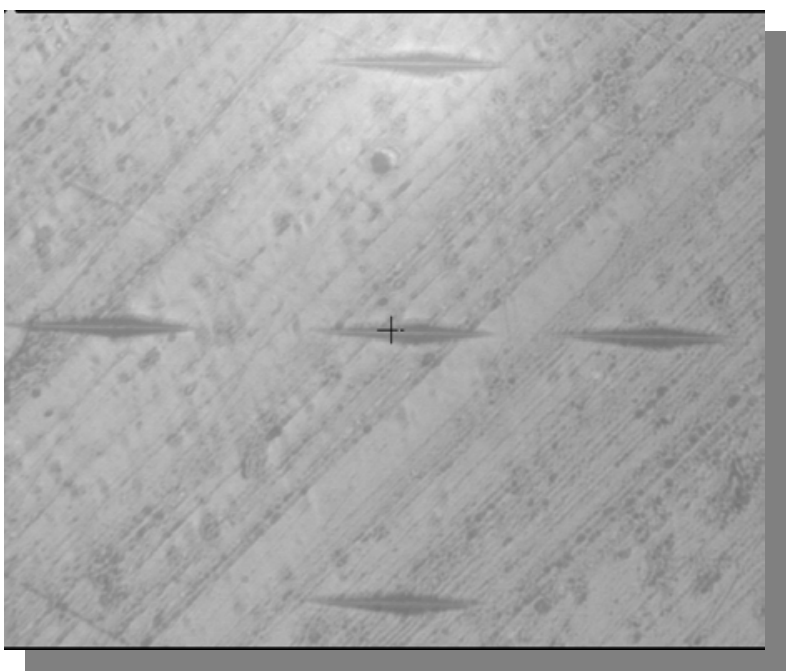

Figura 10 - Localização das marcações no espécime de resina composta.

As diagonais obtidas na imagem formada pela marcação no espécime foram medidas em milímetros e, posteriormente, transformadas em número de dureza Knoop (KHN $\left.-\mathrm{Kgf} / \mathrm{mm}^{2}\right)$, considerando a tabela adequada para a carga e o tempo utilizados. (Figura 11)

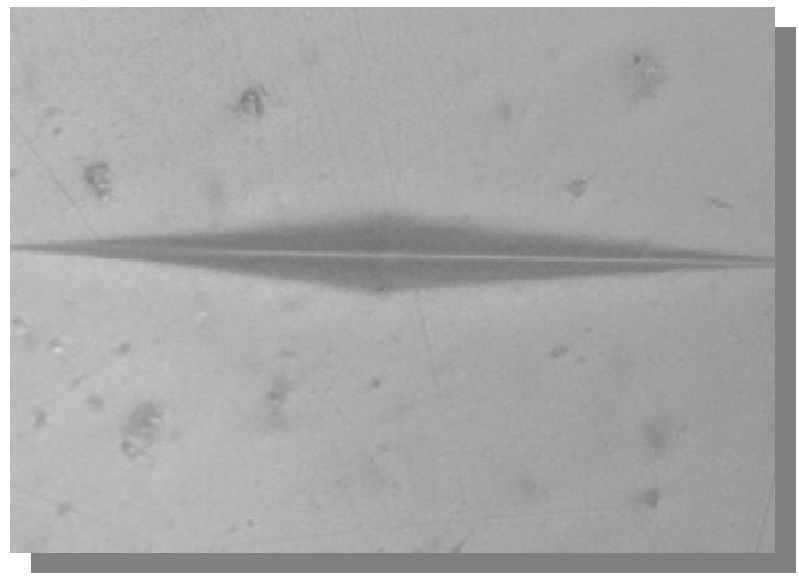

Figura 11 - Imagem da marcação no espécime testado. 
Após 10 minutos da fotoativação, os espécimes foram analisados na superfície de base (oposta à fonte de luz), uma vez que estes testes tinham por objetivo avaliar a microdureza da resina composta na região onde, supostamente, os espécimes teriam se fraturado no teste de tração.

\section{6 - ANÁLISE ESTATÍSTICA}

Os resultados foram submetidos à análise de variância (ANOVA) a três (3) critérios de classificação para determinação de possível significância estatística em função da diferença numérica decorrente dos fatores relacionados ao tipo de fonte polimerizadora, espessura de resina composta polimerizada e influência do tempo de polimerização. Para as comparações individuais, foi utilizado o teste de Tukey. Em ambos os testes, foi estabelecido o nível de significância de 5\% $(p<0,05)$ 
5. Resultados 


\section{5 - Resultados}

\section{RESISTÊNCIA À TRAÇÃO}

Os valores das médias e desvios padrão de cada grupo experimental podem ser observados na tabela 5.

Em face dos resultados da análise estatística, observou-se diferença estatística para os 3 fatores de variação estudados (aparelho, espessura e tempo). Independentemente do tipo de fonte de luz e do tempo de exposição, a espessura do material restaurador influenciou na resistência coesiva da resina composta. A espessura de $2 \mathrm{~mm}$ apresentou valores de resistência à tração estatisticamente superiores à espessura de $1 \mathrm{~mm}$.

No que diz respeito ao desempenho individual dos aparelhos, considerando as variações de tempo de fotoativação, nenhum deles mostrou diferença estatisticamente significante nos valores de resistência à tração para os tempos empregados (20s, $40 \mathrm{~s}$ e $60 \mathrm{~s})$, tanto para os espécimes de $1 \mathrm{~mm}$ como os de $2 \mathrm{~mm}$.

$\mathrm{Na}$ espessura de $1 \mathrm{~mm}$, não houve diferença estatística entre os aparelhos para os tempos de 20 s e 40 s. Ao avaliar o tempo de 60 s de fotoativação, os valores encontrados para o aparelho tipo LED de maior potência - UB6 (1,36MPa) foram estatisticamente superiores aos obtidos pelos demais aparelhos, os quais apresentaram valores de resistência à tração similares entre si (UTL - 1,18MPa; $\mathrm{CL}-0,94 \mathrm{MPa}$ e UB3 - 0,99MPa). (Tabela 5 e Figura 12) 
Tabela 5 - Valores das médias e desvios-padrão de resistência à tração em MPa para a resina composta Filtek Z250 - 3M/ESPE.

\begin{tabular}{|c|c|c|c|c|c|}
\hline GRUPOS & APARELHOS & ESPESSURAS & TEMPOS & MÉDIAS (MPa) & DESVIOS PADRÃO \\
\hline G1 & CL & $1 \mathrm{~mm}$ & $20 \mathrm{~s}$ & $0,98^{a b c *}$ & $\pm 0,29$ \\
\hline G2 & $C L$ & $1 \mathrm{~mm}$ & $40 \mathrm{~s}$ & $1,02^{a b c}$ & $\pm 0,22$ \\
\hline G3 & $C L$ & $1 \mathrm{~mm}$ & $60 \mathrm{~s}$ & $0,94^{a b}$ & $\pm 0,13$ \\
\hline G4 & $\mathrm{CL}$ & $2 \mathrm{~mm}$ & $20 \mathrm{~s}$ & $1,40^{\text {def }}$ & $\pm 0,24$ \\
\hline G5 & $C L$ & $2 \mathrm{~mm}$ & $40 \mathrm{~s}$ & $1,43^{d e f}$ & $\pm 0,24$ \\
\hline G6 & CL & $2 \mathrm{~mm}$ & $60 \mathrm{~s}$ & $1,33^{d e}$ & $\pm 0,21$ \\
\hline G7 & UTL & $1 \mathrm{~mm}$ & $20 \mathrm{~s}$ & $0,99^{a b}$ & $\pm 0,11$ \\
\hline G8 & UTL & $1 \mathrm{~mm}$ & $40 \mathrm{~s}$ & $0,97^{a b}$ & $\pm 0,18$ \\
\hline G9 & UTL & $1 \mathrm{~mm}$ & $60 \mathrm{~s}$ & $1,18^{b c}$ & $\pm 0,26$ \\
\hline G10 & UTL & $2 \mathrm{~mm}$ & $20 \mathrm{~s}$ & $1,19^{d e}$ & $\pm 0,14$ \\
\hline G11 & UTL & $2 \mathrm{~mm}$ & $40 \mathrm{~s}$ & $1,26^{d e}$ & $\pm 0,37$ \\
\hline G12 & UTL & $2 \mathrm{~mm}$ & $60 \mathrm{~s}$ & $1,42^{e f}$ & $\pm 0,31$ \\
\hline G13 & UB3 & $1 \mathrm{~mm}$ & $20 \mathrm{~s}$ & $0,87^{a}$ & $\pm 0,17$ \\
\hline G14 & UB3 & $1 \mathrm{~mm}$ & $40 \mathrm{~s}$ & $1,05^{a b c}$ & $\pm 0,24$ \\
\hline G15 & UB3 & $1 \mathrm{~mm}$ & $60 \mathrm{~s}$ & $0,99^{a b}$ & $\pm 0,19$ \\
\hline G16 & UB3 & $2 \mathrm{~mm}$ & $20 \mathrm{~s}$ & $1,12^{d}$ & $\pm 0,22$ \\
\hline G17 & UB3 & $2 \mathrm{~mm}$ & $40 \mathrm{~s}$ & $1,37^{\mathrm{def}}$ & $\pm 0,30$ \\
\hline G18 & UB3 & $2 \mathrm{~mm}$ & $60 \mathrm{~s}$ & $1,15^{\mathrm{de}}$ & $\pm 0,32$ \\
\hline G19 & UB6 & $1 \mathrm{~mm}$ & $20 \mathrm{~s}$ & $1,02^{a b c}$ & $\pm 0,22$ \\
\hline G20 & UB6 & $1 \mathrm{~mm}$ & $40 \mathrm{~s}$ & $1,02^{a b c}$ & $\pm 0,18$ \\
\hline G21 & UB6 & $1 \mathrm{~mm}$ & $60 \mathrm{~s}$ & $1,36^{c}$ & $\pm 0,24$ \\
\hline G22 & UB6 & $2 \mathrm{~mm}$ & $20 \mathrm{~s}$ & $1,39^{\text {def }}$ & $\pm 0,10$ \\
\hline G23 & UB6 & $2 \mathrm{~mm}$ & $40 \mathrm{~s}$ & $1,45^{d e f}$ & $\pm 0,41$ \\
\hline G24 & UB6 & $2 \mathrm{~mm}$ & $60 \mathrm{~s}$ & $1,48^{f}$ & $\pm 0,33$ \\
\hline
\end{tabular}

* Letras iguais indicam valores estatisticamente semelhantes $(p<0,05)$ 
Resistência à tração para espessura de $1 \mathrm{~mm}$

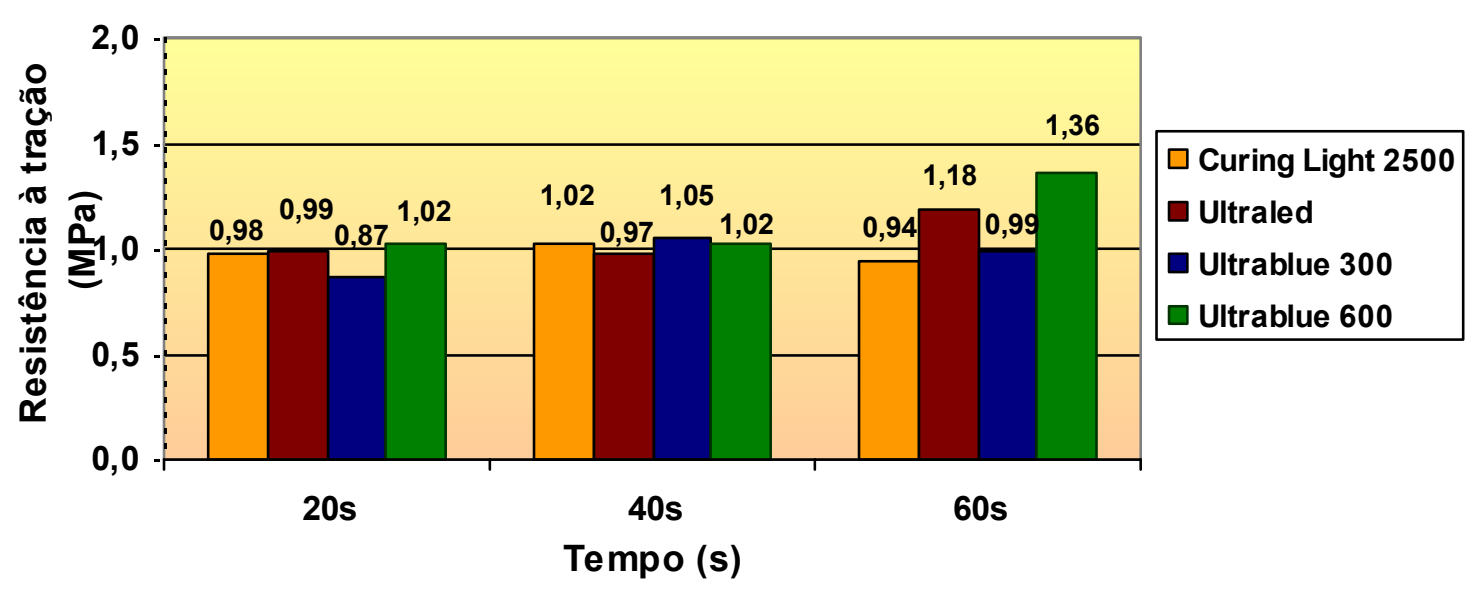

Figura 12 - Representação gráfica da Tabela 5 para espécimes de $1 \mathrm{~mm}$.

Resistência à tração para espessura de $2 \mathrm{~mm}$

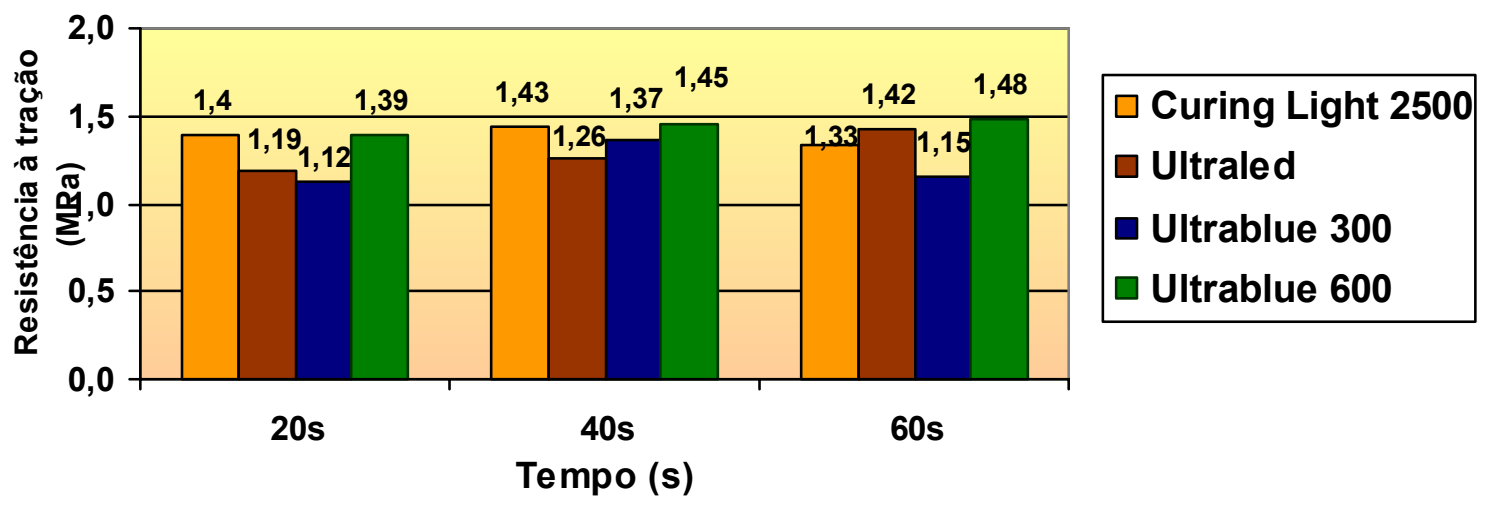

Figura 13 - Representação gráfica da Tabela 5 para espécimes de $2 \mathrm{~mm}$. 
Ao se compararem os valores obtidos na espessura de $2 \mathrm{~mm}$ de material, dados semelhantes foram encontrados, mostrando que não houve diferença entre os aparelhos nos tempos de 20 s e 40 s. Para o tempo de ativação de 60 s, foi observado comportamento similar ao encontrado na espessura de $1 \mathrm{~mm}$, com o UB6 (1,48MPa) apresentando valores semelhantes ao UTL (1,42MPa), e superiores ao CL (1,33MPa) e ao UB3 (1,15MPa), sendo que entre os três últimos citados não se observou diferença estatística. (Figura 13)

\section{MICRODUREZA - INTERFACE CORRESPONDENTE À ÁREA DE UNIÃO}

Tabela 6 - Valores das médias e desvios-padrão da microdureza (KHN) para resina composta Filtek Z250.

\begin{tabular}{|c|c|c|c|c|}
\hline Aparelho & Espessura & Média $(t=20 s)$ & Média $(t=40 s)$ & Média $(t=60 \mathrm{~s})$ \\
\hline $\mathrm{CL}$ & $1 \mathrm{~mm}$ & $61,12 \pm 8,66^{e f}$ & $68,44 \pm 3,03^{f g}$ & $72,10 \pm 5,34^{g}$ \\
\hline $\mathrm{CL}$ & $2 \mathrm{~mm}$ & $61,44 \pm 3,82$ ef $^{f}$ & $64,28 \pm 5,83^{f}$ & $70,24 \pm 3,66^{g}$ \\
\hline UTL & $1 \mathrm{~mm}$ & $38,86 \pm 4,68^{b}$ & $45,98 \pm 4,69 b c$ & $55,06 \pm 5,35^{c d}$ \\
\hline UTL & $2 \mathrm{~mm}$ & $31,04 \pm 2,29 a$ & $41,68 \pm 1,42^{b}$ & $44,56 \pm 6,01^{c}$ \\
\hline UB3 & $1 \mathrm{~mm}$ & $55,37 \pm 2,91^{d}$ & $54,06 \pm 4,30^{d}$ & $57,36 \pm 4,43^{d}$ \\
\hline UB3 & $2 \mathrm{~mm}$ & $46,80 \pm 5,71^{c}$ & $50,50 \pm 3,96^{c d}$ & $51,52 \pm 4,22^{d}$ \\
\hline UB6 & $1 \mathrm{~mm}$ & $45,22 \pm 1,36^{b c}$ & $53,85 \pm 1,87^{d e}$ & $53,66 \pm 3,67^{d}$ \\
\hline UB6 & $2 \mathrm{~mm}$ & $40,66 \pm 3,78^{b}$ & $56,12 \pm 3,69 \mathrm{de}$ & $51,66 \pm 2,57^{d}$ \\
\hline
\end{tabular}

*Letras iguais indicam valores estatisticamente semelhantes $(p<0,05)$ 
Os resultados observados na superfície correspondente à área de união mostraram que os fatores de variação influenciaram na microdureza da resina composta quando fotoativada nas diferentes condições experimentais da presente pesquisa, conforme pode-se notar na tabela 6.

Ao se comparar, individualmente, o desempenho de cada aparelho fotopolimerizador em relação à variação de espessura de material, verificou-se que tanto o UTL $(38,86 \mathrm{KHN})$ como o UB3 $(55,37 \mathrm{KHN})$ apresentaram diferença estatística de microdureza para a espessura de $1 \mathrm{~mm}$, com o tempo de $20 \mathrm{~s}$, em relação à espessura de $2 \mathrm{~mm}(31,04 \mathrm{KHN}$ e $46,80 \mathrm{KHN}$, respectivamente). Com os tempos de 40 s e 60 s não se observou a mesma tendência, verificando-se uma relação direta entre o aumento do tempo de exposição e o valor de dureza. No entanto, os valores para o aparelho de lâmpada halógena (CL) e o LED de maior potência (UB6) não mostraram diferença estatística para as espessuras de $1 \mathrm{~mm}$ e $2 \mathrm{~mm}$.

No que se refere à espessura de material, quando se utilizou incremento de $1 \mathrm{~mm}$, a unidade de lâmpada halógena $(\mathrm{CL})$ demonstrou valores superiores aos demais aparelhos, sendo que para a ativação por 60 s $(72,10 \mathrm{KHN})$ obteve melhores resultados em relação à ativação por 20 s $(61,12 \mathrm{KHN})$, enquanto que para o tempo de 40 s, os valores encontrados foram intermediários $(68,44 \mathrm{KHN})$. O UTL apresentou melhor comportamento quando ativado por 60 s, demonstrando nesse tempo similaridade estatística em relação aos demais aparelhos à base de LED. Ao analisar o desempenho do Ultrablue IS, verificou-se que, na menor potência (UB3), o aparelho mostrou comportamento similar em todas as variações 
de tempo de exposição; ou seja, não houve diferença estatística entre os valores de dureza para as diferentes condições experimentais adotadas $(55,37 \mathrm{KHN}$, $54,06 \mathrm{KHN}$ e $57,36 \mathrm{KHN}$, para 20 s, 40s e 60 s, respectivamente). Por fim, o UB6 demonstrou superioridade nos valores de dureza obtidos quando da fotoativação por 40 s e 60 s $(53,85 \mathrm{KHN}$ e $53,66 \mathrm{KHN})$ em relação à exposição pelo menor tempo (45,22KHN). (Tabela 6 e Figura 14)

Em relação à espessura de $2 \mathrm{~mm}$, notou-se que os valores para o $\mathrm{CL}$ foram superiores, no tempo de $60 \mathrm{~s}(70,24 \mathrm{KHN})$ aos demais tempos de ativação $(61,44 \mathrm{KHN}$ e $64,28 \mathrm{KHN})$. Para o UTL, os valores de dureza foram estatisticamente menores que os dos demais aparelhos, sendo que houve diferença significante entre todos os tempos de exposição (20s - 31,04KHN; 40s - 41,68KHN; 60s - 44,56KHN). Com o maior tempo (60s), o UTL apresentou similaridade ao UB3 $(46,80 \mathrm{KHN})$ quanto à dureza, quando este foi utilizado por 20s. De forma geral, o Ultrablue IS obteve resultados intermediários quando comparados aos demais aparelhos, sendo que as fontes UB3 (20s - 46,80KHN; $40 \mathrm{~s}-50,50 \mathrm{KHN}$ e $60 \mathrm{~s}-51,52 \mathrm{KHN})$ e UB6 $(20 \mathrm{~s}-40,66 \mathrm{KHN} ; 40 \mathrm{~s}-56,12 \mathrm{KHN}$ e 60s - 51,66KHN) não apresentaram diferença estatística para os tempos de fotoativação. (Tabela 6 e Figura 15) 
Microdureza interna material a $1 \mathrm{~mm}$ de espessura

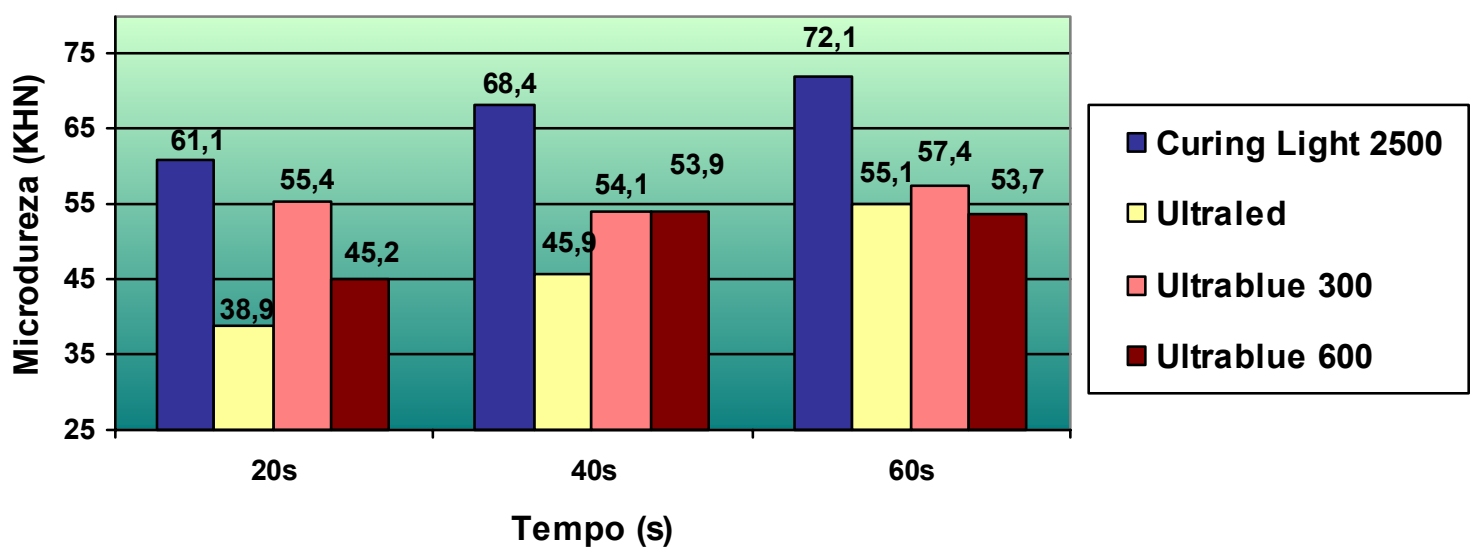

Figura 14 - Representação gráfica da tabela 6 para $1 \mathrm{~mm}$ de espessura de material.

Microdureza interna material a $2 \mathrm{~mm}$ de espessura

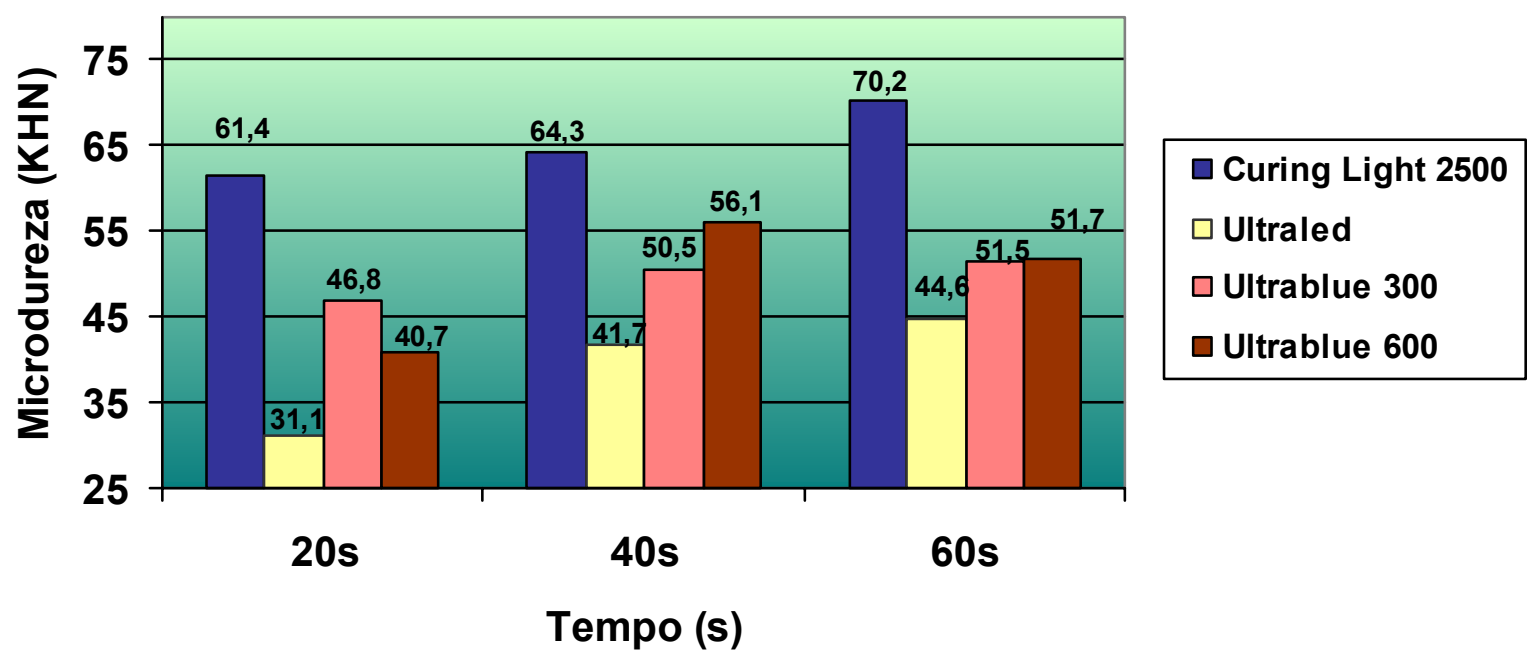

Figura 15 - Representação gráfica da tabela 6 para espessura de $2 \mathrm{~mm}$ de material. 
6. Discussão 


\section{6 - Discussão}

\section{1-Sobre Metodologia}

O grau de polimerização tem sido determinado por diferentes metodologias, envolvendo métodos diretos ou indiretos. Os métodos diretos procuram determinar o grau de conversão de monômeros em polímeros por meio de espectroscopias de infravermelho (FTIR - Fourier Transform Infrared Spectrometer) e de laser Raman, que são análises bastante sensíveis para avaliar a profundidade e grau de polimerização do material. Entretanto, esses equipamentos têm sido distinguidos na rotina de estudos laboratoriais, por serem complexos, onerosos e consumirem maior tempo na consecução da análise ${ }^{63}$. Por outro lado, os métodos indiretos envolvem, entre outros, a análise da microdureza e da profundidade de polimerização por meio de raspagem do material, sendo que este último sobreestima os valores de profundidade, quando comparados aos testes de dureza e do grau de conversão. ${ }^{82}$

O teste de microdureza superficial tem sido um dos mais utilizados para analisar o grau de polimerização por ser o mais simples e menos oneroso dentre os demais tipos de testes citados. De acordo com YEARN (1985) ${ }^{81}$, a dureza mede a resistência de um material à penetração de um dispositivo colocado sobre a superfície do mesmo por um determinado período de tempo, deixando uma impressão. Todavia, se a microdureza for avaliada somente na superfície do 
material, não indicará corretamente a conversão, uma vez que dificilmente será a mesma atingida na região mais distante da fonte de luz.

De acordo com o tipo de ponta e a carga, pode-se ter quatro diferentes tipos de ensaios de dureza: Brinell, Rockwell, Vickers e Knoop. A dureza Knoop é de grande aplicabilidade na Odontologia, consistindo de uma carga aplicada com menor intensidade; sendo assim, considerada como um método para análise de microdureza. É bastante empregada para a avaliação do grau de mineralização de estruturas dentárias mineralizadas, sendo que a dureza destas pode ser comparada a de muitos materiais odontológicos como o ouro, porcelana e resina composta entre outros ${ }^{13,14,56}$ Neste caso, a ponta apresenta forma piramidal, de base rômbica e a demarcação corresponde a um losango, sendo que apenas o eixo maior será utilizado para mensuração da dureza. De forma geral, um material apresentará maior dureza quanto menor for a marcação produzida na superfície, independente do método aplicado. ${ }^{78}$

A análise de dureza Knoop tem mostrado ser um dos melhores métodos indiretos na distinção da eficiência das diferentes fontes de luz no estudo da profundidade de polimerização, comparado a métodos como o de raspagem e de profundidade de penetração. Uma boa correlação tem sido relatada entre a microdureza Knoop e o grau de conversão do monômero no interior da resina composta, quando determinado com espectroscopia por infravermelho. ${ }^{62}$

Entretanto, segundo DUNNE et al. $(1996)^{18}$, o teste de dureza superficial de uma restauração polimerizada, isoladamente, não é um guia adequado para avaliar o grau de polimerização do material, haja vista que a superfície do mesmo 
irá polimerizar invariavelmente, mesmo com uma unidade fotoativadora de baixa potência. Por tal motivo, esse tipo de teste deve ser empregado para estudo não somente na superfície de topo material, como, também, a base deve ser avaliada, para analisar a área mais distante da fonte de luz. Nesse sentido, justifica-se a avaliação da microdureza estabelecida na interface correspondente à região de fratura, uma vez que permite observar à distância a efetividade de polimerização.

Embora pouco considerada nos estudos laboratoriais, maior atenção deveria ser oferecida aos valores de microdureza da região de base da restauração nos estudos in vitro, uma vez que esta superfície não pode ser inspecionada clinicamente e é passível de influenciar no prognóstico da restauração por estar em contato direto com a estrutura dentária e o material adesivo. $^{57}$

Além disso, as propriedades físico-mecânicas dos compósitos são igualmente dependentes do grau de conversão de polimerização; isto é, da qualidade do polímero formado com o uso de determinada fonte de luz e servem para consubstanciar a aplicabilidade clínica de materiais e técnicas. Tendo como base a literatura e as vantagens de se verificar a resistência coesiva da resina composta após ser polimerizada, o teste de resistência à tração foi eleito para o presente trabalho, em concomitância com o teste de dureza, para avaliar a eficiência de diferentes fontes de luz na fotoativação de uma resina composta, quando a espessura de material e o tempo de irradiação de energia luminosa variassem. 
No teste de resistência à tração, uma força age no sentido de provocar a separação da estrutura do material, por meio de forças de mesma direção e sentidos opostos, caracterizando a tensão por tração. Nos ensaios de tração, é comum medir-se a ductibilidade, que é a capacidade do material de se deformar até o ponto de fratura sob forças de tração. Os materiais que se rompem muito rapidamente são considerados materiais frágeis ou friáveis. Em alguns casos, a resistência à tração pode não refletir o comportamento de determinado material, devendo-se modificar, adaptar ou complementar com outro tipo de ensaio. Um exemplo é o que ocorre com os materiais muito frágeis. ${ }^{78}$

Nesse sentido, os ensaios de resistência à tração foram adotados, na presente pesquisa, para correlacionar as propriedades da resina composta analisada, conforme o desempenho das fontes de luz empregadas. Testes realizados por BOSQUIROLI ${ }^{7}$, em 2003, fundamentados na mesma metodologia, mostraram que a resistência coesiva da resina composta não variou, de maneira significativa, ao se utilizar aparelhos do tipo LED com baixa densidade de potência e de lâmpada halógena para polimerizar incrementos de $1 \mathrm{~mm}$ de espessura do material. Nesse mesmo ano, FRANCO et al. (2003) ${ }^{\mathbf{2 5}}$ também avaliaram o comportamento das fontes de luz utilizando como material fotopolimerizável um cimento de ionômero de vidro modificado por resina. A mesma metodologia foi empregada em seu estudo, reafirmando a fundamentação vinculada à presente pesquisa.

Com relação ao emprego da resina composta apenas na cor $A 1$, seu uso decorreu das observações do estudo de BOSQUIROLI (2003) ${ }^{7}$ que não encontrou 
influência do croma da resina, tendo tanto a cor com tonalidade mais clara quanto a mais escura, apresentado valores similares de resistência à tração. Autores como FERRACANE et al. $(1986)^{21}$ também asseguram que, em pequenas espessuras, não há influência dessa característica no processo de polimerização, embora muitos já tenham afirmado que para cores mais claras, espera-se que haja menor absorção da luz pelos pigmentos, permitindo que maior proporção da luz seja transmitida pela resina, resultando em aumento do grau de conversão e da microdureza do material.

Muitas vezes, na rotina dos consultórios odontológicos, a espessura de material considerada ideal pode ser aumentada pelos profissionais, que na tentativa de ganhar tempo de trabalho, acabam inserindo espessuras maiores na cavidade a ser restaurada. Em conseqüência disso, as propriedades do material podem ser afetadas em decorrência da transmissão da luz através do volume da restauração. Dessa forma, é importante, também, avaliar os efeitos da variação de fontes de luz e tempos de ativação em espessuras maiores do compósito. Por esse motivo, a espessura de $2 \mathrm{~mm}$ foi também eleita para o presente estudo, como um incremento plausível na realidade dos consultórios, embora represente o limite clinicamente tolerável para uma polimerização segura ${ }^{26,24,65}$, uma vez que muitos autores como PEREIRA et al.(1997) ${ }^{53}$ e TSAl et al. (2004) ${ }^{76}$ já comprovaram que espessuras acima desta bloqueiam a difusão da luz, dificultando que se atinjam as porções mais profundas do material pelo fato de ser absorvida à medida que penetra pela resina e, assim, o grau de polimerização alcançado nas camadas mais distantes da fonte é inferior ao desejável. Outro fato 
que deve ser considerado quanto à espessura de material diz respeito à contração de polimerização, sendo que quanto maior o volume do incremento de resina, maior contração haverá pela formação das cadeias poliméricas, gerando tensões na interface adesiva entre material restaurador e as paredes cavitárias, cuja magnitude pode afetar a união adesiva, induzindo à formação de fenda marginal junto à restauração. ${ }^{11}$

Portanto, a associação dos testes de resistência à tração com os testes de microdureza da resina composta permite que haja uma complementação das informações adquiridas e, conseqüentemente, um maior embasamento para avaliar as propriedades físico-mecânicas do material quando submetido às condições experimentais da pesquisa.

Com relação às fontes de luz, a seleção de unidades fotoativadoras de diferentes tecnologias (lâmpada halógena e LED) teve por finalidade observar a possível interferência na polimerização dos compósitos, sendo avaliadas quatro diferentes densidades de potência $\left(130 \mathrm{~mW} / \mathrm{cm}^{2}, 300 \mathrm{~mW} / \mathrm{cm}^{2}, 600 \mathrm{~mW} / \mathrm{cm}^{2}\right.$ e $670 \mathrm{~mW} / \mathrm{cm}^{2}$ ), haja vista que trabalhos citados na literatura como o de SANTOS $(2000)^{67}$ relatam que há uma relação direta entre densidade de potência e profundidade de polimerização. A unidade de lâmpada halógena selecionada foi o Curing Light 2500 (3M/ESPE), uma fonte de luz convencional à base de lâmpada halógena, que representou o grupo controle da pesquisa, enquanto que as unidades do tipo LED foram o Ultraled (Dabi-Atlante) de $1^{\text {a }}$ geração, e o Ultrablue IS (DMC) de $2^{\mathrm{a}}$ geração, que tiveram seu desempenho comparado à lâmpada 
halógena no que diz respeito às propriedades mecânicas fornecidas à resina composta ao ser fotoativada com estes aparelhos.

Quanto aos diferentes tempos de exposição selecionados para este estudo (20s, 40s e 60s), foi considerado o tempo recomendado pelo fabricante da resina composta estudada, ou seja, de 20 s e, também, a ponderação de que, ao se empregar aparelhos com diferentes densidades de potência, deve-se analisar a influência do tempo de exposição do material para que se estabeleça a correspondência de densidade de energia, uma vez que a literatura tem reportado essa influência para compensar a menor densidade de potência de alguns aparelhos. ${ }^{23}$ Por tal motivo, decidiu-se comparar o tempo de 40 s, freqüentemente adotado na prática clínica, com um tempo ainda maior de exposição (60s) verificando, assim, a sua influência na polimerização da resina.

Diante do exposto, a metodologia adotada na presente pesquisa possibilitou avaliar, paralelamente, a resistência coesiva da resina composta e a microdureza, em função da variação da densidade de potência dos aparelhos de fotoativação, a espessura de material e os tempos de exposição. 


\section{2 - Sobre os resultados obtidos}

Atualmente, a polimerização dos compósitos dentais tem se constituído num dos principais tópicos de estudo na Odontologia mundial, por ser fator determinante para o desempenho das restaurações diretas fotoativadas. As resinas compostas são materiais restauradores bastante sensíveis à técnica manipulativa, em especial à ativação, uma vez que as características e propriedades finais do material dependem diretamente do grau de polimerização e podem variar de acordo com a quantidade de ligações cruzadas estabelecidas entre as cadeias da matriz orgânica, influenciadas, dentre outros fatores, pela sua composição, pela região do espectro emitido pela fonte de luz, densidade de potência, distância entre ponteira-guia da fonte e material e tempo de irradiação entre outros. ${ }^{12,20,37,64,75}$ Caso não sejam respeitados esses aspectos, muitas de suas propriedades podem ser prejudicadas pela negligência da técnica.

O processo de polimerização da resina composta ocorre por meio da absorção da luz visível pela molécula fotoiniciadora que, na maior parte dos materiais disponíveis no mercado, é a canforoquinona. No momento em que a canforoquinona é estimulada por um comprimento de onda adequado (pico de absorção máxima da luz em $468 \mathrm{~nm}$ ), esta molécula passa de seu estado fundamental para o estado tripleto excitado. Uma combinação da canforoquinona excitada com uma molécula de amina terciária gera um complexo ativo que promoverá a conversão de ambos em radicais livres. O processo de polimerização se inicia nesta etapa, quando os monômeros começam a realizar 
ligações químicas cruzadas e formar cadeias poliméricas. Nesse processo, os fótons emitidos pela fonte de luz interagem com o fotoiniciador e funcionam como fonte de energia necessária para promover a excitação dessas moléculas, bem como para a formação das ligações entre os monômeros resinosos durante a cura do material. ${ }^{51,62,68,81}$

No início da inserção do material na cavidade, a rede de componentes da resina é relativamente fraca e apresenta alta capacidade de escoamento (fase pré-gel). Devido ao fato de as moléculas poderem deslizar para diferentes posições e orientações, além de escoar facilmente, o material pode acomodar-se no preparo cavitário de modo a gerar menor estresse nesse estágio do processo de cura, sem prejuízo à adesão. A contração e o escoamento decrescem gradualmente com o desenvolver da polimerização, conforme o ponto-gel é atingido e, conseqüentemente, ocorre um aumento na rigidez do material, no momento em que a resina atinge a fase pós-gel e não sofre mais escoamento. ${ }^{37}$ Se o estágio inicial de cura for respeitado por modulação da técnica de ativação, como pela técnica gradual ou mesmo por aparelho de menor densidade de potência, a probabilidade de causar uma falha na adesão é menor.

Os prejuízos que a polimerização inadequada desse material pode trazer são: perda de resistência mecânica e coesiva da restauração, infiltração marginal, manchamento, sensibilidade pós-operatória, entre outros, devido a falhas na técnica como, por exemplo, a indicação incorreta de seu uso, falha na adesão à estrutura dentária ou deficiência na polimerização do material. Segundo MIYASAKI et al. (1996) ${ }^{50}$, propriedades mecânicas incluindo resistência à fratura, 
resistência flexural e módulo de elasticidade podem ser propriedades importantes dos materiais restauradores, as quais seriam afetadas por uma polimerização de má qualidade.

Considerando ainda o processo de polimerização, parte da luz penetra na resina composta e sofre o fenômeno da dispersão na interface matriz/partícula, enquanto outra parte é absorvida por estes componentes do material. A luz penetra por meio da superfície da restauração, mas sua absorção ao longo da espessura do material impede que adentre as porções mais profundas. Dessa forma, a luz dilui-se ao atravessar a resina, limitando a profundidade de polimerização, que é inversamente proporcional à dispersão da luz. Tal fato poderia ocasionar uma polimerização insuficiente das camadas que não fossem atingidas pela ação da energia luminosa, devido ao fato de a energia não se difundir igualmente por toda extensão da restauração. ${ }^{32}$ Desse modo, o grau de cura depende da composição da resina composta e da interação entre os fatores que dificultam ou facilitam a transmissão da luz, tais como: propriedades ópticas da mistura matriz/partícula, tamanho e quantidade de partículas, concentração do fotoiniciador e espessura do material. ${ }^{7}$

A própria composição da resina composta pode afetar a profundidade de polimerização. As que apresentam partículas de carga pequenas dispersam mais a luz do que as resinas de partículas maiores. A penetração da luz nos compósitos de pequenas partículas, entretanto, torna-se mais difícil nas regiões mais profundas do material, sendo necessária maior intensidade de irradiação ou tempo de exposição para uma cura adequada. A proporção relativa de carga da 
resina também é um fator importante, pois quanto maior essa proporção, maior a barreira para a luz penetrar no material. ${ }^{48}$ Levando-se em conta que, na presente pesquisa, somente uma marca comercial de resina composta foi selecionada para os experimentos, o fator composição do material não pode ser considerado como influente nos resultados obtidos; porém, os demais fatores devem ser avaliados.

Dentro desse contexto, relatos encontrados na literatura asseguram que dentre os fatores que influenciam o processo de polimerização, no que se refere à resina composta, a espessura do material é o de maior influência. ${ }^{13,34,44,67}$ Para garantir a ampla conversão dos monômeros em polímeros, em todo o volume de material inserido na cavidade, a técnica incremental tem evidenciado vantagens em relação ao incremento único, quando o material restaurador é aplicado em camadas de, no máximo, $2 \mathrm{~mm}$ de resina composta ${ }^{62}$ para obter cura máxima e uniforme, embora a espessura de $1 \mathrm{~mm}$ seja considerada ideal para esses fins.

Pela tabela 5 pode-se notar que o aumento dos tempos de ativação não aumentou, de forma significativa, a resistência à tração da resina estudada, tanto para a espessura de $1 \mathrm{~mm}$ como de $2 \mathrm{~mm}$. Entretanto, pela tabela 6 , observa-se que a dureza na interface de união foi inferior quando se utilizou aparelho com menor densidade de potência (UTL) e tempo de exposição de 20s (densidade de energia $-2,6 \mathrm{~J} / \mathrm{cm}^{2}$ ); porém, não mais encontrado quando o tempo de ativação aumentou para 40s e 60s. Tal fato certifica a validade da afirmação de que incrementos que não excedam a espessura recomendada na literatura (máximo de $2 \mathrm{~mm}$ ) não sofrem grandes influências no grau de polimerização, desde que uma densidade de energia satisfatória seja empregada. 
Sabe-se que a densidade de potência impõe grande influência na polimerização do material, todavia a densidade de energia é considerada como a principal responsável em determinar o grau de conversão monomérica. Para melhor explicar essas duas propriedades do processo, tem-se que densidade de potência, representada pela unidade $\mathrm{mW} / \mathrm{cm}^{2}$, também referida como intensidade de luz ou de irradiância, é definida como o número de fótons por segundo (W) recebidos por um centímetro quadrado do material-alvo, ou seja, a superfície da resina composta, e pode ser afetada por: densidade real de saída da ponteiraguia do aparelho, desenho e diâmetro da ponteira, distância da mesma em relação à superfície da resina composta, espessura, composição, cor e translucidez do compósito. ${ }^{29}$ A densidade de energia, outra característica importante para estabelecer o efetivo grau de polimerização da resina composta, é definida como a associação da densidade de potência com o tempo de ativação. A unidade utilizada para esta propriedade é Joules por centímetroquadrado $\left(\mathrm{J} / \mathrm{cm}^{2}\right)$, calculada multiplicando-se a densidade de potência $\left(\mathrm{mW} / \mathrm{cm}^{2}\right)$ pelo tempo total de exposição à luz em segundos. Se a restauração de resina composta não recebe um número suficiente de fótons em um comprimento de onda apropriado da unidade fotopolimerizadora, o grau e a extensão da polimerização acabam sendo inadequados. ${ }^{51,65}$

Nesse contexto, alguns autores ${ }^{10,80}$ vêm buscando definir a energia ideal para o processo de polimerização ocorrer de maneira adequada, minimizando a proporção de monômeros residuais e, conseqüentemente, os efeitos tóxicos destes à polpa dental. Sabendo que a superfície do material fotoativado não é tão 
susceptível aos efeitos da densidade de potência, quando comparada à base do material, somente a variação do tempo de exposição pode influenciar na conversão dos monômeros. No entanto, o mesmo não pode ser assegurado para a superfície oposta à fonte de luz, uma vez que a dispersão da energia luminosa, ao penetrar no material, diminui a densidade de energia inicial. YAP \& SENEVIRATNE $(2001)^{80}$ investigando a influência da densidade de energia na microdureza da resina composta polimerizada, observaram que a cura apropriada do material na base do incremento pode ser alcançada quando ativado por tempo de 120 s com uma densidade de potência de $300 \mathrm{~mW} / \mathrm{cm}^{2}$, sendo que com $200 \mathrm{~mW} / \mathrm{cm}^{2}$ isso não pôde ser observado. Considerando maiores densidades de potência, a ótima polimerização na base do material também pode ser obtida com irradiância de $30 \mathrm{~s}$ com $500 \mathrm{~mW} / \mathrm{cm}^{2}$ ou por $20 \mathrm{~s}$ com $600 \mathrm{~mW} / \mathrm{cm}^{2}$. Interpretando os dados desse estudo realizado por YAP \& SENEVIRATNE ${ }^{80}$, conclui-se que a energia mínima para se obter um grau de polimerização satisfatório seria de $12 \mathrm{~J} / \mathrm{cm}^{2}$, e que o ideal estaria entre $24 \mathrm{~J} / \mathrm{cm}^{2}$ e $36 \mathrm{~J} / \mathrm{cm}^{2}$ para garantir uma ampla conversão dos monômeros em polímeros. Esses achados vêm corroborar o trabalho de CALHEIROS et al. $(2003)^{10}$ que observaram que a densidade de energia mínima de $27 \mathrm{~J} / \mathrm{cm}^{2}$ foi suficiente para atingir um grau de conversão dos monômeros, uma vez que não se verificou uma correspondência entre densidades mais elevadas a esta, nos casos das resinas estudadas por esses autores, e um maior grau de conversão. Confirmando esses achados, HALVORSON; ERICKSON; DAVIDSON $(2003)^{30}$, observando a relação da energia de conversão com a profundidade de cura das resinas compostas Herculite e Z100, expostas a uma energia de $18 \mathrm{~J} / \mathrm{cm}^{2}$ durante o processo de 
polimerização, notaram que há uma reciprocidade entre os níveis de densidade de potência e o tempo de ativação uma vez que, ao variarem esses fatores de forma que a energia total fosse mantida sempre a mesma, os resultados obtidos para o grau de conversão do material foram semelhantes para as mesmas espessuras, sendo que com o aumento da espessura de material a conversão decrescia exponencialmente. Dessa forma, esses autores sugerem que há uma relação logarítmica entre a profundidade de cura e a energia de exposição requerida pelos compósitos. Entretanto, esses valores de densidade de energia mencionados não podem ser adotados para todos os materiais resinosos, uma vez que as diferentes composições dos materiais implicam em maior ou menor energia total necessária para atingir um grau de polimerização satisfatório.

$\mathrm{Na}$ presente pesquisa, foram utilizadas várias densidades de energia de acordo com as combinações de potência e tempo de exposição para que pudesse ser avaliada a energia que apresentasse o melhor desempenho nas condições experimentais adotadas. Considerando que os valores de densidade de energia para o aparelho de lâmpada halógena (CL) foram de $13,4 \mathrm{~J} / \mathrm{cm}^{2}, 26,8 \mathrm{~J} / \mathrm{cm}^{2}$ e $40,2 \mathrm{~J} / \mathrm{cm}^{2}$ para os tempos de $20 \mathrm{~s}, 40$ s e 60 s, respectivamente, a resina composta estudada alcançou propriedades físico-mecânicas adequadas, tanto para a resistência coesiva como para a microdureza. Em relação ao LED de menor potência (UTL), a energia máxima fornecida pela ativação foi de $7,8 \mathrm{~J} / \mathrm{cm}^{2}$ quando o tempo empregado foi de 60s. Dessa forma, os valores obtidos nos testes realizados foram, evidentemente, inferiores aos observados para o $\mathrm{CL}$, assim como o UB3 mostrou, também, um desempenho semelhante ao UTL, ao ser 
utilizado por tempo de irradiância de $20 \mathrm{~s}$, em que a energia total obtida $\left(6 \mathrm{~J} / \mathrm{cm}^{2}\right)$ apresentava-se inferior ao considerado mínimo para o sucesso da polimerização. Com os maiores tempos e a densidade de potência modulada em $600 \mathrm{~mW} / \mathrm{cm}^{2}$ (UB6), a energia manteve-se dentro da faixa considerada ideal (12 a $36 \mathrm{~J} / \mathrm{cm}^{2}$ ); portanto, houve maior garantia de que a polimerização sofrida pelo material tenha sido adequada.

Ao analisar os dados da tabela 6 comparando o desempenho dos aparelhos de LED, verificou-se que os valores de dureza obtidos para os grupos com espessura de $1 \mathrm{~mm}$ com energia total a partir de $6 \mathrm{~J} / \mathrm{cm}^{2}$, envolvendo os grupos do UTL a 60s e UB3 a 20s, não houve influência da densidade de energia na microdureza da interface correspondente à área de união nos demais grupos, ou seja, mesmo com densidades maiores apresentadas pelos grupos do UB3 a 40 s e 60 s, os valores de dureza foram estatisticamente semelhantes aos obtidos com os $6 \mathrm{~J} / \mathrm{cm}^{2}$. Em relação à espessura de $2 \mathrm{~mm}$, o UTL mostrou-se muito aquém quanto à dureza de seus espécimes em todos os tempos empregados, sugerindo que a densidade de energia utilizada não foi suficiente para obter uma adequada dureza do material, enquanto que o UB3 e o UB6, quando apresentavam energia de $12 \mathrm{~J} / \mathrm{cm}^{2}$ ou superior (UB3 a 40s e UB6 a 20s), seu comportamento se igualou aos grupos com $24 \mathrm{~J} / \mathrm{cm}^{2}$, sendo que esta densidade de energia foi suficiente para obter resultados similares aos alcançados com maiores energias de ativação.

Em relação ao aparelho de lâmpada halógena (CL), observou-se que, com as altas densidades de energia estabelecidas, todos os grupos mostraram bom comportamento quanto à dureza; todavia, esse fato também está associado à 
maior liberação de calor, que acelera a indução da formação de cadeias poliméricas da resina composta, por aumentar a mobilidade das moléculas durante a reação e permitir que mais monômeros reajam antes da desaceleração do processo de cura. ${ }^{42}$

Frente ao exposto, fica evidente a importância de se conhecer as características das fontes de luz utilizadas na fotopolimerização das resinas compostas. Portanto, para que se considere uma unidade fotoativadora ideal, três aspectos são relevantes: tempo mínimo de exposição de luz, redução de estresse interno do material pelo prolongamento da fase pré-gel e irradiância de densidades de potência suficientes para desencadear fotoiniciação sem, no entanto, promover aquecimento demasiado. ${ }^{8}$

Embora os aparelhos convencionais baseados na lâmpada halógena sejam comumente utilizados na cura das resinas, exibem desvantagens inerentes. $O$ bulbo da lâmpada tem um tempo de vida efetiva limitado (aproximadamente 50100hs). Bulbo, refletor e filtro degradam com o tempo de uso devido às altas temperaturas produzidas, levando a redução na densidade de potência emitida. A implicação clínica disso para o cirurgião-dentista é o efeito negativo nas propriedades físico-mecânicas dos compósitos, com um aumento do risco de falha prematura da restauração. ${ }^{6,14}$

As unidades de polimerização com alta densidade de potência, que operam com tempo mínimo de exposição, têm sido recomendadas por produzir profundidade de cura e resistência mecânica suficientes, além de economia de tempo para realizar esse tipo de procedimento. Todavia, elas podem ter algumas 
influências desagradáveis advindas da alta intensidade, como a maior contração de polimerização, resultando em microinfiltração ao redor da restauração. ${ }^{50}$

Estudos prévios ${ }^{28,48,79}$ mostraram que a adaptação marginal de resinas compostas fotopolimerizáveis pode ser conseguida ou melhorada através de polimerização lenta e com baixa densidade de potência. KORAN \& KURSCHNER $(1998)^{37}$ afirmam que um grau de conversão mais lento permite melhor escoamento do material, o que diminui o estresse da contração, conduzindo a uma adaptação marginal mais eficiente. Quando o material é fotopolimerizado com baixa densidade de potência, a sua adaptação às paredes cavitárias é significantemente maior, o que pode ser atribuído ao melhor escoamento do material durante a presa. Portanto, uma restauração bem sucedida com resina composta depende da combinação de taxa ótima de contração, boa capacidade de escoamento, cura adequada e resistência mecânica satisfatória.

Os métodos de modulação da fotoativação surgiram na tentativa de conciliar o melhor escoamento do material (prolongamento da fase pré-gel), e sua importância está em favorecer o relaxamento das tensões de contração, com a obtenção de adequado grau de conversão dos monômeros. ${ }^{24}$ Por tal motivo, a associação da baixa densidade de potência inicial com a alta densidade final no processo de polimerização é uma técnica de fotoativação encontrada nos aparelhos mais recentemente desenvolvidos, como do tipo "Soft-Start" ou "Pulse Delay" (pulso interrompido ou de espera), que empregam esse modo de ativação para obter melhores resultados com as restaurações de resina composta. 
Outro aspecto que deve ser considerado, quando da fotopolimerização, segundo relatado por $\mathrm{LOPES}^{41}$, em 2003, relacionado ainda à contração de polimerização gerada durante a cura da resina composta, são as diferentes formas de atuação das fontes de luz, uma vez que a técnica convencional de ativação induz à geração de maiores tensões no material. Em seu estudo, mostrou que o aparelho à base de LED (1ª geração), quando utilizado para ativar alguns sistemas de compósitos, foi capaz de promover menores valores de contração ao ser comparado com aparelhos convencionais de lâmpada halógena devido à polimerização mais lenta. Isso vem ao encontro do que tem sido abordado pelos pesquisadores ${ }^{21,28,36,45,72}$, reafirmando que essa nova tecnologia em fotoativação pode implementar benefícios às propriedades do material restaurador direto.

No presente estudo, a fonte de luz dotada de lâmpada halógena (Curing Light 2500 - 3M/ESPE), empregada como controle para a comparação do desempenho dos demais aparelhos estudados, apresenta a mais alta densidade de potência $-670 \mathrm{~mW} / \mathrm{cm}^{2}$ - tendo demonstrado um comportamento diferenciado em relação ao LED, tanto no que se refere à resistência à tração como na microdureza da resina composta. Já em relação aos aparelhos à base de diodos emissores de luz (LEDs), o de $1^{a}$ geração (Ultraled - Dabi/Atlante), com baixa densidade de potência $\left(130 \mathrm{~mW} / \mathrm{cm}^{2}\right)$, demonstrou bom desempenho para incrementos de resina em espessuras de $1 \mathrm{~mm}$ com períodos de ativação mais prolongados, tendo no teste de tração apresentado resultados semelhantes à unidade halógena quando utilizado no tempo de 60s. Ademais, o aparelho 
Ultrablue IS (DMC), que permite a modulação da densidade em 300 e $600 \mathrm{~mW} / \mathrm{cm}^{2}$, apresentou comportamento mais próximo ao da unidade de lâmpada halógena para ambas as situações, alcançando condições similares de grau de polimerização do compósito. O trabalho de BALA; ÖLMEZ; KALAYCI $(2005)^{5}$ vem corroborar esses resultados uma vez que, em sua pesquisa, utilizando um LED de média densidade de potência $\left(400 \mathrm{~mW} / \mathrm{cm}^{2}\right)$ para fotoativação, obteve dados semelhantes quando comparado com um aparelho de lâmpada halógena $\left(600 \mathrm{~mW} / \mathrm{cm}^{2}\right)$ em decorrência do melhor aproveitamento da energia absorvida pelo material, por emitir luz na faixa espectral coincidente com a faixa de absorção da canforoquinona.

Nesse mesmo direcionamento, PRICE; FELIX; ANDREOU ${ }^{59}$, em 2003, relatam que para um aparelho fotopolimerizador do tipo LED de $1^{\text {a }}$ geração, contendo múltiplos diodos emissores de luz e apresentando baixa densidade de potência, como é o caso do UTL $\left(130 \mathrm{~mW} / \mathrm{cm}^{2}\right)$, o aspecto da densidade de potência implicou em menor grau de polimerização em relação às unidades convencionais de lâmpada halógena. A segunda geração de aparelhos de LED está disponível no mercado odontológico, semelhante ao Ultrablue IS, apresentando somente 1 LED de alta-potência, oferecendo uma maior densidade de potência, sendo que esse aspecto proporcionou melhor desempenho clínico e menores tempos de ativação do material fotopolimerizável. Corroborando o estudo supracitado, quando se analisaram os dados obtidos no presente trabalho, observou-se que o aparelho de LED de baixa densidade de potência $\left(130 \mathrm{~mW} / \mathrm{cm}^{2}\right)$ somente apresentou valores muito aquém em relação aos demais 
aparelhos quando a espessura da resina composta foi de $2 \mathrm{~mm}$, uma vez que as densidades de energia empregadas não foram suficientes para ativar a polimerização em toda a extensão do incremento. Para espécimes com $1 \mathrm{~mm}$, considerando os tempos de ativação de 40 s e 60 s, o desempenho foi similar ao Ultrablue IS, em média e alta potência e, numericamente, mais próximo ao aparelho convencional de lâmpada halógena, tanto em relação à resistência coesiva quanto à microdureza. Provavelmente a formação de cadeias poliméricas longas e rigidez atingidas permitam que o material ceda elasticamente, compensando o menor grau de polimerização durante o teste de tração. Em estudos relatados na literatura, comportamento similar pôde ser notado para o aparelho de LED de $1^{\text {a }}$ geração (UTL), como no trabalho de FERRAREZI et. al. ${ }^{22}$ (2003) que, ao testarem a microdureza Knoop de algumas resinas compostas, observaram que na região de topo, ambos os aparelhos (CL e UTL) apresentaram valores satisfatórios; no entanto, na região de base dos corpos-de-prova, o UTL mostrou valores de dureza significantemente menores que o aparelho convencional, tendo os mesmos autores afirmado que o LED estudado não foi capaz de produzir a mesma microdureza nos materiais resinosos como o foi a lâmpada halógena. A pesquisa de RIBEIRO et al. $(2003)^{61}$ também apresenta resultados que comprovam os encontrados no presente estudo, em que o Ultraled (UTL) teve seu desempenho analisado e comparado com o de outros aparelhos fotoativadores em relação à microdureza da resina composta Z250; esses autores notaram que os LEDs de $2^{a}$ geração apresentaram os maiores valores de dureza, seguido do aparelho de lâmpada halógena testado; o Ultraled (LED de baixa densidade de potência) mostrou os menores resultados quando testado seu 
potencial de polimerização na base dos corpos-de-prova com $2 \mathrm{~mm}$ de espessura. Concordando com esses trabalhos, ATMADJA e BRYANT ${ }^{4}$, em 1990, já salientavam que é preferível utilizar incrementos mais finos $(1 \mathrm{~mm})$ de resina a aumentar o tempo de exposição para otimizar a polimerização de incrementos maiores ou mais espessos.

Por outro lado, existem trabalhos reportados na literatura demonstrando que as unidades de luz tipo LED, com baixa densidade de potência, quando comparadas com as unidades de luz halógena podem alcançar melhores profundidades de cura $^{48,52}$, o que seria justificado pela estreita faixa de emissão de energia no comprimento de onda que coincide com a faixa de absorção da canforoquinona $^{35}$, fato não observado pelos resultados obtidos no presente trabalho.

No entanto, controvérsias têm sido apontadas pela literatura enfatizando que, embora a baixa densidade de potência possa polimerizar adequadamente a superfície do material mais próxima à fonte de luz, o número de fótons que atinge a porção mais distante do material é reduzido exponencialmente à medida que a espessura aumenta. ${ }^{29,58}$ Mais recentemente, autores como LEONARD et al., $2002^{40}$; SOH et al., $2003^{70}$; e UHL et al, $2003^{77}$, ainda asseguram que o desempenho desses aparelhos é inferior aos convencionais de lâmpada halógena, especialmente se utilizados para polimerizar resinas que contenham co-iniciadores em adição à canforoquinona. No presente estudo, a resina composta analisada (Filtek Z250) não apresenta co-iniciadores em sua composição, mostrando que seu fotoiniciador, a canforoquinona, pode ser 
sensibilizado pelos fótons emitidos durante a ativação, haja vista que o pico de absorção situa-se bem próximo ao comprimento de onda emitido pelas unidades de LED estudadas, sendo que esse fator não pode ser considerado como responsável pelas diferenças observadas nas propriedades mecânicas.

Muito embora a literatura apresente, para os resultados de testes de dureza, a significância baseada em análise estatística, autores como PRICE; FELIX; ANDREOU $(2003)^{60}$ consideram que um guia válido para determinar se a base da resina composta está adequadamente polimerizada é estabelecer uma relação de até $20 \%$ entre o valor máximo de dureza adquirido para o compósito e o menor valor de dureza da base, ou seja, região mais distante da fonte de luz ativadora. Uma microdureza na base equivalente a $80-90 \%$ da dureza superficial é cientificamente considerada um valor aceitável para a profundidade de polimerização. ${ }^{54,57,81}$ No presente estudo procurou-se associar a microdureza na interface correspondente à área de união com a dureza máxima verificada e sua correspondência com a alcançada pelos demais aparelhos. O valor de dureza máxima encontrado na interface correspondente à área de união foi obtido para os espécimes fotoativados com o $\mathrm{CL}(72,10 \mathrm{KHN})$; no tempo de exposição de 20 s, somente o UB3 $(55,37 \mathrm{KHN})$ com $1 \mathrm{~mm}$ de espessura atingiu polimerização satisfatória $(90,6 \%)$, sendo que os demais grupos apresentaram proporção inferior aos $80 \%$ sugeridos para uma polimerização ideal. No tempo de ativação de 40 s, o Ultrablue IS, em ambas as densidades de potência e espessuras (1 e $2 \mathrm{~mm}$ ), obteve valores de dureza suficientemente altos (acima de $80 \%$ ) quando comparados com o CL. Por fim, ao analisar os valores de dureza quando a 
ativação foi de $60 \mathrm{~s}$, verificou-se que os grupos do UTL e do UB3 com $1 \mathrm{~mm}$ de espessura alcançaram os resultados mais próximos ao CL (76,4\% e 79,9\%), tendo os outros grupos obtido menores valores de dureza.

Não obstante a preocupação em observar o grau de polimerização alcançado nas porções mais profundas dos incrementos de resina composta, por ocasião do melhor comportamento do material, PILO E CARDASH (1992) ${ }^{57}$, em estudo sobre as alterações no padrão de microdureza do material fotopolimerizado, observaram que, na região de base da resina composta, os valores de dureza Knoop encontrados foram diferentes para os tempos de ativação de 40s e 60s. Afirmam que isso ocorre devido à maior quantidade de moléculas de canforoquinona que permanecem não excitadas nas camadas mais profundas do compósito após cessar a irradiação da luz nos tempos de ativação menores. Ao contrário, quando os tempos de ativação eram mais prolongados, os valores de microdureza da base e do topo tornam-se similares ou bem mais próximos.

É possível que altas densidades de potência, em tempos de irradiação mais prolongados, produzam mais radicais livres inicialmente, causando uma reação mais rápida. ${ }^{57} \mathrm{~A}$ geração de maiores quantidades de radicais livres por unidade de volume na condição de alta densidade de potência proporciona a formação de cadeias com menor peso molecular e, também, à maior formação de monômeros residuais ${ }^{47}$; conseqüentemente, haverá uma polimerização parcial do material, aumentando a solubilidade e sorpção de água, o que pode afetar a longevidade e estética da restauração. ${ }^{16}$ 
Nesse sentido, deve-se considerar que, quando uma restauração de resina composta não recebe uma energia total suficiente, em um comprimento de onda apropriado da unidade polimerizadora, os efeitos de desgaste podem ser aumentados, assim como deteriorização das margens da restauração, diminuição da resistência adesiva entre resina-dente, dureza e módulo de elasticidade. Conseqüentemente, o profissional deve usar aparelhos que permitam alcançar energia total suficiente no comprimento de onda adequado. ${ }^{59}$ Por tal motivo, fazse necessário enfatizar a relevância no fato do fabricante informar, no rótulo do material, a densidade de energia suficiente para polimerizá-lo adequadamente, uma vez que não foi estabelecido na literatura um único valor que corresponda a todos os materiais disponíveis no mercado devido às particularidades inerentes a cada um.

Salientando o aspecto de se manter a energia total de polimerização para o melhor desempenho do material, ASENJO-MARTINEZ², em 2004, realizou um estudo sobre o desgaste superficial da resina composta Filtek Z250, utilizando o aparelho de LED Ultrablue IS em comparação com um aparelho de lâmpada halógena, sendo que quando o LED foi empregado na menor densidade de potência $\left(300 \mathrm{~mW} / \mathrm{cm}^{2}\right)$, observou que o comportamento físico-mecânico foi consideravelmente inferior ao apresentado na maior densidade $\left(600 \mathrm{~mW} / \mathrm{cm}^{2}\right)$ e também pela fonte de luz halógena. Tal fato mostra que a polimerização rápida conseguida com as densidades mais altas ocasionou uma estrutura polimérica mais rígida e estável, favorecendo a resistência ao desgaste. O mesmo não pôde 
ser verificado quando a menor densidade foi empregada, devido à formação de uma estrutura mais flexível e, portanto, mais sensível ao desgaste.

No que se refere aos resultados encontrados para a resistência à tração, determinado enfoque deve ser dado para o fato de que os maiores valores foram notados para a espessura de $2 \mathrm{~mm}$ do material em relação à espessura de $1 \mathrm{~mm}$, havendo uma diferença estatística significante entre as referidas espessuras, independentemente do tipo de fonte de luz e do tempo de ativação. Não obstante a expectativa de que o inverso fosse observado, ou seja, que valores de resistência maiores fossem atribuídos aos espécimes com menor espessura do compósito, haja vista que o aumento da espessura de material acarretaria em menor grau de polimerização e, conseqüentemente, menor resistência coesiva, pode-se justificar esses resultados com base em duas hipóteses. A primeira diz respeito ao maior grau de polimerização ou rigidez dos espécimes de $1 \mathrm{~mm}$, pelo fato de a luz conseguir se difundir mais facilmente pelo material e induzir mais rapidamente a formação de cadeias poliméricas, se comparado aos espécimes de $2 \mathrm{~mm}$ de espessura, estabelecendo um maior módulo de elasticidade e, de forma correspondente, uma maior friabilidade. Com os espécimes de $2 \mathrm{~mm}$ de espessura, o inverso ocorreu, ou seja, a penetração da luz até a porção mais distante da fonte parece mais lenta para esta espessura, devido ao maior volume do material dificultar a difusão da luz e, conseqüentemente, influenciar na formação das cadeias poliméricas que se caracterizam por ser mais longas e mais flexíveis. Se esses dados de resistência à tração forem correlacionados com os resultados encontrados no teste de microdureza do presente trabalho, esse 
conceito pode ser reforçado. Na interface correspondente à área de união houve uma tendência, para a maioria das condições experimentais, em se obter valores de microdureza numericamente superiores para os espécimes com $1 \mathrm{~mm}$ de espessura, quando comparados com os de $2 \mathrm{~mm}$, embora poucos tenham apresentado diferença significante para ambas as espessuras estudadas (UTL e UB3 ativados por 20s). Isso mostra que, em menor espessura, o material apresentou maior rigidez em função da sua estrutura interna de cadeias poliméricas formadas, induzindo a fratura com menor valor de carga, uma vez que sendo mais rígido o mesmo não cedeu elasticamente como estruturas menos rígidas, como os espécimes de $2 \mathrm{~mm}$ de espessura.

Corroborando esse conceito, SOH e YAP ${ }^{71}$, em 2004, salientam que, em espessuras menores, a conversão dos monômeros acontece mais facilmente e há uma tendência do material se tornar mais rígido. Já no caso de espessuras maiores, a conversão do monômero, no entanto, nunca se completa efetivamente e, geralmente, permanecem consideráveis quantidades de duplas ligações pendentes. A redução do efeito da densidade de cruzamento das ligações na cura da resina composta pode levar à diminuição da dureza e da resistência à solubilidade. Não obstante ser desejável que a resina composta alcance altos níveis de conversão, sempre há uma significante concentração de duplas ligações de carbono que não reagiram, resultando em monômeros residuais. Isso acontece devido a limitações na mobilidade das espécies reativas impostas pela rápida formação de ligações cruzadas na rede de cadeias poliméricas. 
Ainda, segundo SOH e YAP $(2004)^{71}$, o grau de conversão, apesar de ser um fator importante, não dá a completa caracterização das estruturas poliméricas. A conversão é uma média e não leva em consideração as áreas de alta e baixa conversão, podendo demonstrar a mesma quantidade de duplas ligações remanescentes como um material polimerizado homogeneamente. Além disso, os polímeros podem diferir quanto à sua linearidade e diferentes densidades de ligações cruzadas, mas com valores similares de conversão. Os autores ainda destacaram que a técnica do pulso interrompido ou de espera, ou seja, com ativação inicial com menor densidade de potência, resulta em uma estrutura polimérica com menor densidade de ligações cruzadas e que esse tipo de técnica está associada, relativamente, com a formação de poucos centros de polímeros, favorecendo a formação de mais cadeias lineares com poucas ligações cruzadas, ou seja, cadeias mais longas. Por outro lado, uma polimerização rápida, devido à alta densidade de potência empregada, desde o início da ativação, pode iniciar a formação de múltiplos centros de formação de cadeias e o polímero apresentar, dessa forma, alta densidade de ligações cruzadas, o que resulta em cadeias mais curtas. A rápida e contínua polimerização tende a resultar num polímero com maior número de ligações cruzadas quando comparada com a técnica de cura por pulso interrompido. Tal afirmação, também, foi reportada por SAKAGUCHI; BERGE $(1998)^{66}$, em um de seus estudos, em que afirmavam que a polimerização rápida pode levar à formação de cadeias curtas e que essa rapidez na cura do material não permite suficiente tempo para a fase pré-gel, quando o compósito poderia absorver o estresse de contração gerado. Tais diferenças de formação de cadeia provenientes do tipo de fotopolimerização e das densidades 
de potência utilizadas permitem que o material, após a sua exposição à luz, apresente-se com maior ou menor flexibilidade, conforme tenha sua estrutura linear ou em rede, respectivamente. Isso pode ser observado no presente estudo, quando se analisa a resistência à tração para a resina empregada, pois os grupos com maior espessura de material $(2 \mathrm{~mm})$, devido à difusão da luz até a região mais distante da fonte ser mais lenta, apresentaram uma estrutura polimérica mais flexível e, portanto, mais resistente à força de tração aplicada.

Dentre os fatores que influenciam na formação da cadeia polimérica a extensão da rede de cadeias cruzadas tem um importante papel nas propriedades do polímero. Sistemas com baixa densidade dessas ligações tendem a ser mais flexíveis e menos duros, enquanto que os polímeros com altos graus de cadeias cruzadas são rígidos e inflexíveis, sendo que essa estrutura do monômero influencia nas propriedades físicas do polímero formado. ${ }^{71}$ Provavelmente, essa condição de flexibilidade, novamente, demonstra a relação existente no fato de a resina ter apresentado maior resistência à tração, quando a espessura de material foi maior, em todas as condições de tempo de exposição e fontes de luz testadas.

A segunda hipótese pode estar relacionada à configuração da matriz utilizada nos experimentos e que pode ser embasada pelas leis da Física. Devido ao fato de a matriz de aço empregada para os espécimes de $2 \mathrm{~mm}$ de espessura apresentar uma maior superfície de contato interno com o material, uma maior distribuição das forças vetoriais é estabelecida, gerando menor concentração da força aplicada na região de união entre os segmentos da matriz e, 
conseqüentemente, necessidade de maior força de tração para que os espécimes se rompam.

Em relação aos tempos de ativação empregados neste estudo, observouse que não houve diferença estatística em relação aos valores de resistência à tração para os tempos de 20 s e 40s. No entanto, quando se utilizou a ativação por 60s, O LED Ultrablue IS, com máxima densidade de potência $\left(600 \mathrm{~mW} / \mathrm{cm}^{2}\right)$, demonstrou superioridade em seus resultados, com valores de resistência de 1,36MPa, enquanto que, na média potência, o mesmo aparelho mostrou valores de $0,99 \mathrm{MPa}$, e os demais obtiveram 1,18MPa e 0,94MPa (Ultraled e Curing Light, respectivamente). Pode-se inferir que a densidade total de energia $\left(36 \mathrm{~J} / \mathrm{cm}^{2}\right)$ atingida, nessas condições experimentais, embora menor que a energia proporcionada pelo $\mathrm{CL}\left(40,2 \mathrm{~J} / \mathrm{cm}^{2}\right)$, permitiu que o material apresentasse melhor desempenho com o UB6, confirmando a hipótese de que a associação densidade de potência com o tempo adequado de irradiação da luz sobre o material é fator determinante no alcance de melhores graus de polimerização. $^{24}$ Tal comportamento foi observado tanto para os espécimes com $1 \mathrm{~mm}$ quanto para aqueles com 2mm de espessura, tendo o UB6 se apresentado superior às demais unidades fotopolimerizadoras, ao se considerar a propriedade de resistência coesiva do material. A condição da unidade de lâmpada halógena ter apresentado valores inferiores de resistência à tração pode ser explicado pelo fato de a polimerização mais rápida promover maior liberação de calor, implicando em maior rigidez, o que pode ser confirmado pelos valores de dureza observados e, portanto, maior facilidade para sofrer a fratura devido a sua friabilidade. Dessa 
forma, observou-se que não houve correlação entre as propriedades de resistência coesiva e microdureza do material, haja vista que a maior resistência não implicou em microdureza superior.

Não obstante toda a preocupação e tendência com o aumento da densidade dos aparelhos para efetivação da polimerização da resina composta, configura-se que cada material apresenta característica individual de polimerização, de tal sorte que os fabricantes deveriam especificar no rótulo do material a identificação quanto à densidade de energia para ativação, uma vez que o aumento da densidade de potência pode inferir em aspectos desfavoráveis no comportamento da restauração. Dessa forma, os cirurgiões-dentistas têm a ferramenta para adaptar em seus consultórios a utilização dos aparelhos fotoativadores que possuem, considerando a densidade de potência que apresentam, devendo apenas variar o tempo de irradiância para alcançar a energia total previamente recomendada no rótulo do material.

Comparando-se as tabelas 5 e 6 do presente trabalho, esses relatos ficam mais evidentes ao se observar o comportamento do Ultraled (UTL), por demonstrar uma alta resistência à tração para os grupos com espessura de $2 \mathrm{~mm}$; porém os mesmos apresentaram microdureza significantemente inferior aos grupos com espessura de $1 \mathrm{~mm}$, mostrando que a baixa densidade de potência possibilitou um grau de conversão inferior para aqueles espécimes em que a luz deveria percorrer uma maior extensão de resina composta para atingir a base do incremento. Em relação aos diferentes tempos de irradiância, observou-se que a densidade de potência não foi o fator que mais influenciou nos resultados de 
microdureza obtidos, mas sim, a densidade de energia gerada pois, no tempo de 60 s, verificou-se a similaridade entre os valores encontrados para todos os aparelhos de LED (UTL, UB3 e UB6). Isso mostra que, ao se considerar as densidades de potência mais elevadas, houve sobreexposição do material, uma vez que a densidade de $7,8 \mathrm{~J} / \mathrm{cm}^{2}$, foi suficiente para alcançar níveis adequados de polimerização.

É válido ressaltar que o aumento da temperatura proporcionado pela fonte do tipo halógena, em comparação com a fonte à base de LED, possa influenciar no comportamento da resina composta, pois há uma relação direta entre aumento da temperatura e maior grau de conversão. ${ }^{73}$ Sabe-se que a taxa de polimerização do compósito pode ser elevada pela geração de calor durante a fotoativação e que isso induz uma melhora nas propriedades mecânicas da restauração. ${ }^{74}$ Dessa forma, a diferença na produção de calor observada nos diferentes aparelhos testados na presente pesquisa pode explicar a maior dureza notada para os grupos polimerizados com aparelho de lâmpada halógena. ${ }^{36}$

Em face do exposto, o presente trabalho evidencia que a tecnologia LED pode ser empregada na fotopolimerização dos materiais resinosos, por permitir que as propriedades físico-mecânicas almejadas sejam alcançadas, desde que determinados princípios de sua utilização sejam respeitados. Para isso, é importante conhecer a densidade de potência do aparelho fotoativador e o tempo de exposição ideal para o material a ser polimerizado, de acordo com a densidade de energia total recomendada pelo fabricante, e, adicionalmente, não exceder a espessura adequada para que a fonte de luz possa obter o mesmo desempenho 
que as unidades convencionais de lâmpada halógena. No entanto, para as unidades de LED com baixa densidade de potência como o Ultraled, a ativação de incrementos com espessura ideal de $1 \mathrm{~mm}$ propicia melhores propriedades ao polímero, sendo observado pelo presente trabalho comportamento inferior aos demais aparelhos estudados, quando incremento maior foi utilizado. 
7. Conclusões 


\section{7 - CONCLUSÕES}

Após a análise estatística dos resultados obtidos, pode-se concluir que:

$\checkmark$ No que diz respeito ao desempenho individual dos aparelhos avaliados, houve similaridade na resistência à tração para os diferentes tempos empregados (20s, 40s e 60s), tanto para espessura de $1 \mathrm{~mm}$ como de $2 \mathrm{~mm}$.

$\checkmark$ A resistência à tração da resina composta mostrou-se superior para espessura de $2 \mathrm{~mm}$, enquanto que a microdureza, na área correspondente à interface de união, apresentou valores maiores para a espessura de $1 \mathrm{~mm}$, demonstrando que uma maior microdureza não implica em resistência à tração superior.

$\checkmark$ Com relação à microdureza do material, a lâmpada halógena alcançou resultados superiores às fontes de LED.

$\checkmark$ A variação da espessura do material e do tempo de exposição não influenciou na microdureza da interface de união para os diferentes aparelhos, mas evidenciou que aparelhos de menor densidade de potência necessitam de maior tempo de ativação para se equipararem às fontes com maior irradiância. 
Anexo 1 - Quadro com VAlores de REsistência À traçÃo (KGF) OBTIDOS PARA CADA ESPÉCIME TESTADO.

\begin{tabular}{|c|c|c|c|}
\hline APARELHO & ESPESSURA & TEMPO & TRAÇÃO (KGF) \\
\hline CL & $1 \mathrm{~mm}$ & $20 \mathrm{~s}$ & 12,500 \\
\hline CL & $1 \mathrm{~mm}$ & $20 \mathrm{~s}$ & 14,725 \\
\hline CL & $1 \mathrm{~mm}$ & $20 \mathrm{~s}$ & 7,200 \\
\hline CL & $1 \mathrm{~mm}$ & $20 \mathrm{~s}$ & 7,625 \\
\hline CL & $1 \mathrm{~mm}$ & $20 \mathrm{~s}$ & 12,625 \\
\hline CL & $1 \mathrm{~mm}$ & $20 \mathrm{~s}$ & 7,500 \\
\hline CL & $1 \mathrm{~mm}$ & $20 \mathrm{~s}$ & 6,450 \\
\hline CL & $1 \mathrm{~mm}$ & $20 \mathrm{~s}$ & 11,375 \\
\hline CL & $1 \mathrm{~mm}$ & $20 \mathrm{~s}$ & 12,200 \\
\hline CL & $1 \mathrm{~mm}$ & $20 \mathrm{~s}$ & 7,600 \\
\hline CL & $2 \mathrm{~mm}$ & $20 \mathrm{~s}$ & 13,350 \\
\hline CL & $2 \mathrm{~mm}$ & $20 \mathrm{~s}$ & 12,750 \\
\hline CL & $2 \mathrm{~mm}$ & $20 \mathrm{~s}$ & 14,875 \\
\hline CL & $2 \mathrm{~mm}$ & $20 \mathrm{~s}$ & 13,050 \\
\hline CL & $2 \mathrm{~mm}$ & $20 \mathrm{~s}$ & 11,725 \\
\hline CL & $2 \mathrm{~mm}$ & $20 \mathrm{~s}$ & 17,350 \\
\hline CL & $2 \mathrm{~mm}$ & $20 \mathrm{~s}$ & 12,750 \\
\hline CL & $2 \mathrm{~mm}$ & $20 \mathrm{~s}$ & 14,925 \\
\hline CL & $2 \mathrm{~mm}$ & $20 \mathrm{~s}$ & 12,375 \\
\hline CL & $2 \mathrm{~mm}$ & $20 \mathrm{~s}$ & 19,325 \\
\hline CL & $1 \mathrm{~mm}$ & $40 \mathrm{~s}$ & 8,475 \\
\hline CL & $1 \mathrm{~mm}$ & $40 \mathrm{~s}$ & 10,050 \\
\hline
\end{tabular}




\begin{tabular}{|c|c|c|c|}
\hline CL & $1 \mathrm{~mm}$ & $40 \mathrm{~s}$ & 8,550 \\
\hline$C L$ & $1 \mathrm{~mm}$ & $40 \mathrm{~s}$ & 12,450 \\
\hline CL & $1 \mathrm{~mm}$ & $40 \mathrm{~s}$ & 13,600 \\
\hline $\mathrm{CL}$ & $1 \mathrm{~mm}$ & $40 \mathrm{~s}$ & 8,675 \\
\hline CL & $1 \mathrm{~mm}$ & $40 \mathrm{~s}$ & 13,475 \\
\hline CL & $1 \mathrm{~mm}$ & $40 \mathrm{~s}$ & 12,000 \\
\hline CL & $1 \mathrm{~mm}$ & $40 \mathrm{~s}$ & 8,075 \\
\hline CL & $1 \mathrm{~mm}$ & $40 \mathrm{~s}$ & 8,850 \\
\hline CL & $2 \mathrm{~mm}$ & $40 \mathrm{~s}$ & 16,025 \\
\hline$C L$ & $2 \mathrm{~mm}$ & $40 \mathrm{~s}$ & 11,350 \\
\hline CL & $2 \mathrm{~mm}$ & $40 \mathrm{~s}$ & 16,675 \\
\hline$C L$ & $2 \mathrm{~mm}$ & $40 \mathrm{~s}$ & 14,025 \\
\hline CL & $2 \mathrm{~mm}$ & $40 \mathrm{~s}$ & 13,975 \\
\hline $\mathrm{CL}$ & $2 \mathrm{~mm}$ & $40 \mathrm{~s}$ & 16,325 \\
\hline CL & $2 \mathrm{~mm}$ & $40 \mathrm{~s}$ & 18,325 \\
\hline$C L$ & $2 \mathrm{~mm}$ & $40 \mathrm{~s}$ & 15,125 \\
\hline CL & $2 \mathrm{~mm}$ & $40 \mathrm{~s}$ & 10,775 \\
\hline CL & $2 \mathrm{~mm}$ & $40 \mathrm{~s}$ & 12,750 \\
\hline $\mathrm{CL}$ & $1 \mathrm{~mm}$ & $60 \mathrm{~s}$ & 8,025 \\
\hline$C L$ & $1 \mathrm{~mm}$ & $60 \mathrm{~s}$ & 9,125 \\
\hline $\mathrm{CL}$ & $1 \mathrm{~mm}$ & $60 s$ & 10,525 \\
\hline$C L$ & $1 \mathrm{~mm}$ & $60 \mathrm{~s}$ & 8,425 \\
\hline CL & $1 \mathrm{~mm}$ & $60 \mathrm{~s}$ & 8,175 \\
\hline $\mathrm{CL}$ & $1 \mathrm{~mm}$ & $60 \mathrm{~s}$ & 11,925 \\
\hline CL & $1 \mathrm{~mm}$ & $60 s$ & 11,325 \\
\hline $\mathrm{CL}$ & $1 \mathrm{~mm}$ & $60 \mathrm{~s}$ & 8,650 \\
\hline CL & $1 \mathrm{~mm}$ & $60 \mathrm{~s}$ & 9,475 \\
\hline $\mathrm{CL}$ & $1 \mathrm{~mm}$ & $60 \mathrm{~s}$ & 10,100 \\
\hline
\end{tabular}




\begin{tabular}{|c|c|c|c|}
\hline CL & $2 \mathrm{~mm}$ & $60 \mathrm{~s}$ & 11,950 \\
\hline CL & $2 \mathrm{~mm}$ & $60 \mathrm{~s}$ & 16,550 \\
\hline CL & $2 \mathrm{~mm}$ & $60 \mathrm{~s}$ & 13,875 \\
\hline CL & $2 \mathrm{~mm}$ & $60 \mathrm{~s}$ & 12,375 \\
\hline CL & $2 \mathrm{~mm}$ & $60 \mathrm{~s}$ & 9,375 \\
\hline CL & $2 \mathrm{~mm}$ & $60 \mathrm{~s}$ & 15,300 \\
\hline CL & $2 \mathrm{~mm}$ & $60 \mathrm{~s}$ & 14,200 \\
\hline CL & $2 \mathrm{~mm}$ & $60 \mathrm{~s}$ & 15,825 \\
\hline CL & $2 \mathrm{~mm}$ & $60 \mathrm{~s}$ & 12,225 \\
\hline CL & $2 \mathrm{~mm}$ & $60 \mathrm{~s}$ & 13,575 \\
\hline UTL & $1 \mathrm{~mm}$ & $20 \mathrm{~s}$ & 9,700 \\
\hline UTL & $1 \mathrm{~mm}$ & $20 \mathrm{~s}$ & 8,175 \\
\hline UTL & $1 \mathrm{~mm}$ & $20 \mathrm{~s}$ & 10,975 \\
\hline UTL & $1 \mathrm{~mm}$ & $20 \mathrm{~s}$ & 11,075 \\
\hline UTL & $1 \mathrm{~mm}$ & $20 \mathrm{~s}$ & 9,725 \\
\hline UTL & $1 \mathrm{~mm}$ & $20 \mathrm{~s}$ & 9,700 \\
\hline UTL & $1 \mathrm{~mm}$ & $20 \mathrm{~s}$ & 8,950 \\
\hline UTL & $1 \mathrm{~mm}$ & $20 \mathrm{~s}$ & 12,150 \\
\hline UTL & $1 \mathrm{~mm}$ & $20 \mathrm{~s}$ & 10,150 \\
\hline UTL & $1 \mathrm{~mm}$ & $20 \mathrm{~s}$ & 9,525 \\
\hline UTL & $2 \mathrm{~mm}$ & $20 \mathrm{~s}$ & 11,075 \\
\hline UTL & $2 \mathrm{~mm}$ & $20 \mathrm{~s}$ & 10,525 \\
\hline UTL & $2 \mathrm{~mm}$ & $20 \mathrm{~s}$ & 12,750 \\
\hline UTL & $2 \mathrm{~mm}$ & $20 \mathrm{~s}$ & 14,225 \\
\hline UTL & $2 \mathrm{~mm}$ & $20 \mathrm{~s}$ & 10,975 \\
\hline UTL & $2 \mathrm{~mm}$ & $20 \mathrm{~s}$ & 13,175 \\
\hline UTL & $2 \mathrm{~mm}$ & $20 \mathrm{~s}$ & 11,825 \\
\hline UTL & $2 \mathrm{~mm}$ & $20 \mathrm{~s}$ & 14,675 \\
\hline
\end{tabular}




\begin{tabular}{|c|c|c|c|}
\hline UTL & $2 \mathrm{~mm}$ & $20 s$ & 10,875 \\
\hline UTL & $2 \mathrm{~mm}$ & $20 s$ & 11,650 \\
\hline UTL & $1 \mathrm{~mm}$ & $40 s$ & 7,175 \\
\hline UTL & $1 \mathrm{~mm}$ & $40 s$ & 11,575 \\
\hline UTL & $1 \mathrm{~mm}$ & $40 s$ & 7,825 \\
\hline UTL & $1 \mathrm{~mm}$ & $40 s$ & 11,800 \\
\hline UTL & $1 \mathrm{~mm}$ & $40 s$ & 7,700 \\
\hline UTL & $1 \mathrm{~mm}$ & $40 s$ & 11,575 \\
\hline UTL & $1 \mathrm{~mm}$ & $40 s$ & 11,825 \\
\hline UTL & $1 \mathrm{~mm}$ & $40 s$ & 8,550 \\
\hline UTL & $1 \mathrm{~mm}$ & $40 \mathrm{~s}$ & 10,475 \\
\hline UTL & $1 \mathrm{~mm}$ & $40 \mathrm{~s}$ & 10,300 \\
\hline UTL & $2 \mathrm{~mm}$ & $40 \mathrm{~s}$ & 7,675 \\
\hline UTL & $2 \mathrm{~mm}$ & $40 s$ & 10,575 \\
\hline UTL & $2 \mathrm{~mm}$ & $40 s$ & 10,450 \\
\hline UTL & $2 \mathrm{~mm}$ & $40 \mathrm{~s}$ & 8,650 \\
\hline UTL & $2 \mathrm{~mm}$ & $40 s$ & 13,450 \\
\hline UTL & $2 \mathrm{~mm}$ & $40 \mathrm{~s}$ & 18,350 \\
\hline UTL & $2 \mathrm{~mm}$ & $40 s$ & 18,750 \\
\hline UTL & $2 \mathrm{~mm}$ & $40 s$ & 14,825 \\
\hline UTL & $2 \mathrm{~mm}$ & $40 s$ & 13,500 \\
\hline UTL & $2 \mathrm{~mm}$ & $40 s$ & 12,175 \\
\hline UTL & $1 \mathrm{~mm}$ & $60 \mathrm{~s}$ & 9,500 \\
\hline UTL & $1 \mathrm{~mm}$ & $60 \mathrm{~s}$ & 10,900 \\
\hline UTL & $1 \mathrm{~mm}$ & $60 \mathrm{~s}$ & 10,325 \\
\hline UTL & $1 \mathrm{~mm}$ & $60 \mathrm{~s}$ & 10,975 \\
\hline UTL & $1 \mathrm{~mm}$ & $60 \mathrm{~s}$ & 16,925 \\
\hline UTL & $1 \mathrm{~mm}$ & $60 s$ & 10,350 \\
\hline
\end{tabular}




\begin{tabular}{|c|c|c|c|}
\hline UTL & $1 \mathrm{~mm}$ & $60 \mathrm{~s}$ & 10,500 \\
\hline UTL & $1 \mathrm{~mm}$ & $60 \mathrm{~s}$ & 10,900 \\
\hline UTL & $1 \mathrm{~mm}$ & $60 \mathrm{~s}$ & 13,350 \\
\hline UTL & $1 \mathrm{~mm}$ & $60 \mathrm{~s}$ & 16,650 \\
\hline UTL & $2 \mathrm{~mm}$ & $60 \mathrm{~s}$ & 12,975 \\
\hline UTL & $2 \mathrm{~mm}$ & $60 \mathrm{~s}$ & 18,675 \\
\hline UTL & $2 \mathrm{~mm}$ & $60 \mathrm{~s}$ & 15,625 \\
\hline UTL & $2 \mathrm{~mm}$ & $60 \mathrm{~s}$ & 17,000 \\
\hline UTL & $2 \mathrm{~mm}$ & $60 \mathrm{~s}$ & 16,675 \\
\hline UTL & $2 \mathrm{~mm}$ & $60 \mathrm{~s}$ & 10,700 \\
\hline UTL & $2 \mathrm{~mm}$ & $60 \mathrm{~s}$ & 16,375 \\
\hline UTL & $2 \mathrm{~mm}$ & $60 \mathrm{~s}$ & 15,775 \\
\hline UTL & $2 \mathrm{~mm}$ & $60 \mathrm{~s}$ & 11,075 \\
\hline UTL & $2 \mathrm{~mm}$ & $60 \mathrm{~s}$ & 9,600 \\
\hline UB3 & $1 \mathrm{~mm}$ & $20 \mathrm{~s}$ & 11,450 \\
\hline UB3 & $1 \mathrm{~mm}$ & $20 \mathrm{~s}$ & 8,275 \\
\hline UB3 & $1 \mathrm{~mm}$ & $20 \mathrm{~s}$ & 10,175 \\
\hline UB3 & $1 \mathrm{~mm}$ & $20 \mathrm{~s}$ & 9,375 \\
\hline UB3 & $1 \mathrm{~mm}$ & $20 \mathrm{~s}$ & 8,500 \\
\hline UB3 & $1 \mathrm{~mm}$ & $20 s$ & 10,625 \\
\hline UB3 & $1 \mathrm{~mm}$ & $20 s$ & 9,450 \\
\hline UB3 & $1 \mathrm{~mm}$ & $20 s$ & 7,100 \\
\hline UB3 & $1 \mathrm{~mm}$ & $20 \mathrm{~s}$ & 5,600 \\
\hline UB3 & $1 \mathrm{~mm}$ & $20 \mathrm{~s}$ & 8,325 \\
\hline UB3 & $2 \mathrm{~mm}$ & $20 s$ & 10,500 \\
\hline UB3 & $2 \mathrm{~mm}$ & $20 \mathrm{~s}$ & 10,975 \\
\hline UB3 & $2 \mathrm{~mm}$ & $20 s$ & 15,500 \\
\hline UB3 & $2 \mathrm{~mm}$ & $20 s$ & 12,700 \\
\hline
\end{tabular}




\begin{tabular}{|c|c|c|c|}
\hline UB3 & $2 \mathrm{~mm}$ & $20 s$ & 12,150 \\
\hline UB3 & $2 \mathrm{~mm}$ & $20 s$ & 11,800 \\
\hline UB3 & $2 \mathrm{~mm}$ & $20 \mathrm{~s}$ & 11,075 \\
\hline UB3 & $2 \mathrm{~mm}$ & $20 \mathrm{~s}$ & 7,450 \\
\hline UB3 & $2 \mathrm{~mm}$ & $20 \mathrm{~s}$ & 13,150 \\
\hline UB3 & $2 \mathrm{~mm}$ & $20 s$ & 8,975 \\
\hline UB3 & $1 \mathrm{~mm}$ & $40 s$ & 10,000 \\
\hline UB3 & $1 \mathrm{~mm}$ & $40 s$ & 10,925 \\
\hline UB3 & $1 \mathrm{~mm}$ & $40 s$ & 13,175 \\
\hline UB3 & $1 \mathrm{~mm}$ & $40 \mathrm{~s}$ & 10,975 \\
\hline UB3 & $1 \mathrm{~mm}$ & $40 \mathrm{~s}$ & 10,700 \\
\hline UB3 & $1 \mathrm{~mm}$ & $40 s$ & 7,075 \\
\hline UB3 & $1 \mathrm{~mm}$ & $40 s$ & 11,425 \\
\hline UB3 & $1 \mathrm{~mm}$ & $40 s$ & 9,225 \\
\hline UB3 & $1 \mathrm{~mm}$ & $40 \mathrm{~s}$ & 8,125 \\
\hline UB3 & $1 \mathrm{~mm}$ & $40 s$ & 15,450 \\
\hline UB3 & $2 \mathrm{~mm}$ & $40 s$ & 10,250 \\
\hline UB3 & $2 \mathrm{~mm}$ & $40 s$ & 14,975 \\
\hline UB3 & $2 \mathrm{~mm}$ & $40 s$ & 12,175 \\
\hline UB3 & $2 \mathrm{~mm}$ & $40 s$ & 16,475 \\
\hline UB3 & $2 \mathrm{~mm}$ & $40 s$ & 19,500 \\
\hline UB3 & $2 \mathrm{~mm}$ & $40 s$ & 17,825 \\
\hline UB3 & $2 \mathrm{~mm}$ & $40 s$ & 12,750 \\
\hline UB3 & $2 \mathrm{~mm}$ & $40 s$ & 10,600 \\
\hline UB3 & $2 \mathrm{~mm}$ & $40 s$ & 10,825 \\
\hline UB3 & $2 \mathrm{~mm}$ & $40 s$ & 14,350 \\
\hline UB3 & $1 \mathrm{~mm}$ & $60 \mathrm{~s}$ & 8,725 \\
\hline UB3 & $1 \mathrm{~mm}$ & $60 s$ & 13,900 \\
\hline
\end{tabular}




\begin{tabular}{|c|c|c|c|}
\hline UB3 & $1 \mathrm{~mm}$ & $60 \mathrm{~s}$ & 8,000 \\
\hline UB3 & $1 \mathrm{~mm}$ & $60 \mathrm{~s}$ & 10,150 \\
\hline UB3 & $1 \mathrm{~mm}$ & $60 \mathrm{~s}$ & 11,750 \\
\hline UB3 & $1 \mathrm{~mm}$ & $60 \mathrm{~s}$ & 10,050 \\
\hline UB3 & $1 \mathrm{~mm}$ & $60 \mathrm{~s}$ & 7,375 \\
\hline UB3 & $1 \mathrm{~mm}$ & $60 \mathrm{~s}$ & 9,700 \\
\hline UB3 & $1 \mathrm{~mm}$ & $60 \mathrm{~s}$ & 10,050 \\
\hline UB3 & $1 \mathrm{~mm}$ & $60 \mathrm{~s}$ & 11,200 \\
\hline UB3 & $2 \mathrm{~mm}$ & $60 \mathrm{~s}$ & 10,275 \\
\hline UB3 & $2 \mathrm{~mm}$ & $60 \mathrm{~s}$ & 8,475 \\
\hline UB3 & $2 \mathrm{~mm}$ & $60 \mathrm{~s}$ & 17,850 \\
\hline UB3 & $2 \mathrm{~mm}$ & $60 \mathrm{~s}$ & 9,650 \\
\hline UB3 & $2 \mathrm{~mm}$ & $60 \mathrm{~s}$ & 12,525 \\
\hline UB3 & $2 \mathrm{~mm}$ & $60 \mathrm{~s}$ & 14,275 \\
\hline UB3 & $2 \mathrm{~mm}$ & $60 \mathrm{~s}$ & 15,525 \\
\hline UB3 & $2 \mathrm{~mm}$ & $60 \mathrm{~s}$ & 11,775 \\
\hline UB3 & $2 \mathrm{~mm}$ & $60 \mathrm{~s}$ & 8,075 \\
\hline UB3 & $2 \mathrm{~mm}$ & $60 \mathrm{~s}$ & 9,225 \\
\hline UB6 & $1 \mathrm{~mm}$ & $20 \mathrm{~s}$ & 11,600 \\
\hline UB6 & $1 \mathrm{~mm}$ & $20 \mathrm{~s}$ & 8,425 \\
\hline UB6 & $1 \mathrm{~mm}$ & $20 \mathrm{~s}$ & 9,000 \\
\hline UB6 & $1 \mathrm{~mm}$ & $20 \mathrm{~s}$ & 11,650 \\
\hline UB6 & $1 \mathrm{~mm}$ & $20 s$ & 14,475 \\
\hline UB6 & $1 \mathrm{~mm}$ & $20 s$ & 8,275 \\
\hline UB6 & $1 \mathrm{~mm}$ & $20 s$ & 12,000 \\
\hline UB6 & $1 \mathrm{~mm}$ & $20 \mathrm{~s}$ & 8,475 \\
\hline UB6 & $1 \mathrm{~mm}$ & $20 s$ & 12,175 \\
\hline UB6 & $1 \mathrm{~mm}$ & $20 \mathrm{~s}$ & 7,850 \\
\hline
\end{tabular}




\begin{tabular}{|c|c|c|c|}
\hline UB6 & $2 \mathrm{~mm}$ & $20 \mathrm{~s}$ & 14,000 \\
\hline UB6 & $2 \mathrm{~mm}$ & $20 \mathrm{~s}$ & 14,750 \\
\hline UB6 & $2 \mathrm{~mm}$ & $20 \mathrm{~s}$ & 14,200 \\
\hline UB6 & $2 \mathrm{~mm}$ & $20 \mathrm{~s}$ & 14,375 \\
\hline UB6 & $2 \mathrm{~mm}$ & $20 \mathrm{~s}$ & 16,425 \\
\hline UB6 & $2 \mathrm{~mm}$ & $20 \mathrm{~s}$ & 13,425 \\
\hline UB6 & $2 \mathrm{~mm}$ & $20 \mathrm{~s}$ & 13,625 \\
\hline UB6 & $2 \mathrm{~mm}$ & $20 \mathrm{~s}$ & 13,950 \\
\hline UB6 & $2 \mathrm{~mm}$ & $20 \mathrm{~s}$ & 12,600 \\
\hline UB6 & $2 \mathrm{~mm}$ & $20 \mathrm{~s}$ & 14,100 \\
\hline UB6 & $1 \mathrm{~mm}$ & $40 \mathrm{~s}$ & 11,000 \\
\hline UB6 & $1 \mathrm{~mm}$ & $40 \mathrm{~s}$ & 9,525 \\
\hline UB6 & $1 \mathrm{~mm}$ & $40 \mathrm{~s}$ & 7,475 \\
\hline UB6 & $1 \mathrm{~mm}$ & $40 \mathrm{~s}$ & 13,150 \\
\hline UB6 & $1 \mathrm{~mm}$ & $40 \mathrm{~s}$ & 8,700 \\
\hline UB6 & $1 \mathrm{~mm}$ & $40 \mathrm{~s}$ & 13,350 \\
\hline UB6 & $1 \mathrm{~mm}$ & $40 \mathrm{~s}$ & 11,100 \\
\hline UB6 & $1 \mathrm{~mm}$ & $40 \mathrm{~s}$ & 10,250 \\
\hline UB6 & $1 \mathrm{~mm}$ & $40 \mathrm{~s}$ & 9,425 \\
\hline UB6 & $1 \mathrm{~mm}$ & $40 \mathrm{~s}$ & 9,500 \\
\hline UB6 & $2 \mathrm{~mm}$ & $40 \mathrm{~s}$ & 10,925 \\
\hline UB6 & $2 \mathrm{~mm}$ & $40 \mathrm{~s}$ & 8,725 \\
\hline UB6 & $2 \mathrm{~mm}$ & $40 \mathrm{~s}$ & 20,125 \\
\hline UB6 & $2 \mathrm{~mm}$ & $40 \mathrm{~s}$ & 11,850 \\
\hline UB6 & $2 \mathrm{~mm}$ & $40 \mathrm{~s}$ & 17,125 \\
\hline UB6 & $2 \mathrm{~mm}$ & $40 \mathrm{~s}$ & 18,700 \\
\hline UB6 & $2 \mathrm{~mm}$ & $40 \mathrm{~s}$ & 11,900 \\
\hline UB6 & $2 \mathrm{~mm}$ & $40 \mathrm{~s}$ & 13,925 \\
\hline
\end{tabular}




\begin{tabular}{|c|c|c|c|}
\hline UB6 & $2 \mathrm{~mm}$ & $40 s$ & 13,450 \\
\hline UB6 & $2 \mathrm{~mm}$ & $40 s$ & 20,575 \\
\hline UB6 & $1 \mathrm{~mm}$ & $60 \mathrm{~s}$ & 9,850 \\
\hline UB6 & $1 \mathrm{~mm}$ & $60 s$ & 12,375 \\
\hline UB6 & $1 \mathrm{~mm}$ & $60 s$ & 10,850 \\
\hline UB6 & $1 \mathrm{~mm}$ & $60 \mathrm{~s}$ & 15,025 \\
\hline UB6 & $1 \mathrm{~mm}$ & $60 s$ & 13,925 \\
\hline UB6 & $1 \mathrm{~mm}$ & $60 s$ & 16,750 \\
\hline UB6 & $1 \mathrm{~mm}$ & $60 \mathrm{~s}$ & 16,950 \\
\hline UB6 & $1 \mathrm{~mm}$ & $60 s$ & 16,350 \\
\hline UB6 & $1 \mathrm{~mm}$ & $60 s$ & 12,675 \\
\hline UB6 & $1 \mathrm{~mm}$ & $60 \mathrm{~s}$ & 13,725 \\
\hline UB6 & $2 \mathrm{~mm}$ & $60 \mathrm{~s}$ & 13,525 \\
\hline UB6 & $2 \mathrm{~mm}$ & $60 \mathrm{~s}$ & 17,750 \\
\hline UB6 & $2 \mathrm{~mm}$ & $60 \mathrm{~s}$ & 12,350 \\
\hline UB6 & $2 \mathrm{~mm}$ & $60 s$ & 19,850 \\
\hline UB6 & $2 \mathrm{~mm}$ & $60 \mathrm{~s}$ & 11,650 \\
\hline UB6 & $2 \mathrm{~mm}$ & $60 s$ & 20,825 \\
\hline UB6 & $2 \mathrm{~mm}$ & $60 \mathrm{~s}$ & 14,725 \\
\hline UB6 & $2 \mathrm{~mm}$ & $60 \mathrm{~s}$ & 11,075 \\
\hline UB6 & $2 \mathrm{~mm}$ & $60 s$ & 15,075 \\
\hline UB6 & $2 \mathrm{~mm}$ & $60 \mathrm{~s}$ & 13,950 \\
\hline
\end{tabular}


ANEXO 2 - QUADRO COM VALORES DE MICRODUREZA (KHN) OBTIDOS PARA CADA ESPÉCIME TESTADO.

\begin{tabular}{|c|c|c|c|}
\hline APARELHO & ESPESSURA & TEMPO & MICRODUREZA (KHN) \\
\hline CL & $1 \mathrm{~mm}$ & 20s & 60,54 \\
\hline CL & $1 \mathrm{~mm}$ & $20 \mathrm{~s}$ & 46,88 \\
\hline CL & $1 \mathrm{~mm}$ & $20 \mathrm{~s}$ & 66,42 \\
\hline CL & $1 \mathrm{~mm}$ & $20 s$ & 62,44 \\
\hline CL & $1 \mathrm{~mm}$ & $20 \mathrm{~s}$ & 69,30 \\
\hline $\mathrm{CL}$ & $2 \mathrm{~mm}$ & $20 s$ & 57,92 \\
\hline CL & $2 \mathrm{~mm}$ & $20 \mathrm{~s}$ & 61,66 \\
\hline CL & $2 \mathrm{~mm}$ & $20 s$ & 57,64 \\
\hline CL & $2 \mathrm{~mm}$ & $20 s$ & 66,76 \\
\hline CL & $2 \mathrm{~mm}$ & $20 s$ & 63,20 \\
\hline CL & $1 \mathrm{~mm}$ & $40 \mathrm{~s}$ & 70,62 \\
\hline CL & $1 \mathrm{~mm}$ & $40 s$ & 64,54 \\
\hline CL & $1 \mathrm{~mm}$ & $40 \mathrm{~s}$ & 67,24 \\
\hline CL & $1 \mathrm{~mm}$ & $40 \mathrm{~s}$ & 72,24 \\
\hline CL & $1 \mathrm{~mm}$ & $40 \mathrm{~s}$ & 67,54 \\
\hline CL & $2 \mathrm{~mm}$ & $40 \mathrm{~s}$ & 59,20 \\
\hline CL & $2 \mathrm{~mm}$ & $40 \mathrm{~s}$ & 58,90 \\
\hline CL & $2 \mathrm{~mm}$ & $40 \mathrm{~s}$ & 69,26 \\
\hline CL & $2 \mathrm{~mm}$ & $40 \mathrm{~s}$ & 62,50 \\
\hline CL & $2 \mathrm{~mm}$ & $40 \mathrm{~s}$ & 71,56 \\
\hline$C L$ & $1 \mathrm{~mm}$ & $60 \mathrm{~s}$ & 79,06 \\
\hline$C L$ & $1 \mathrm{~mm}$ & $60 \mathrm{~s}$ & 73,52 \\
\hline$C L$ & $1 \mathrm{~mm}$ & $60 \mathrm{~s}$ & 71,42 \\
\hline CL & $1 \mathrm{~mm}$ & $60 \mathrm{~s}$ & 72,42 \\
\hline CL & $1 \mathrm{~mm}$ & $60 \mathrm{~s}$ & 64,06 \\
\hline
\end{tabular}




\begin{tabular}{|c|c|c|c|}
\hline CL & $2 \mathrm{~mm}$ & $60 \mathrm{~s}$ & 65,22 \\
\hline CL & $2 \mathrm{~mm}$ & $60 \mathrm{~s}$ & 68,52 \\
\hline CL & $2 \mathrm{~mm}$ & $60 \mathrm{~s}$ & 74,56 \\
\hline CL & $2 \mathrm{~mm}$ & $60 \mathrm{~s}$ & 70,08 \\
\hline CL & $2 \mathrm{~mm}$ & $60 s$ & 72,82 \\
\hline UTL & $1 \mathrm{~mm}$ & $20 s$ & 32,00 \\
\hline UTL & $1 \mathrm{~mm}$ & $20 s$ & 41,50 \\
\hline UTL & $1 \mathrm{~mm}$ & $20 s$ & 40,00 \\
\hline UTL & $1 \mathrm{~mm}$ & $20 \mathrm{~s}$ & 44,10 \\
\hline UTL & $1 \mathrm{~mm}$ & $20 s$ & 36,70 \\
\hline UTL & $2 \mathrm{~mm}$ & $20 \mathrm{~s}$ & 31,00 \\
\hline UTL & $2 \mathrm{~mm}$ & $20 \mathrm{~s}$ & 32,40 \\
\hline UTL & $2 \mathrm{~mm}$ & $20 \mathrm{~s}$ & 27,10 \\
\hline UTL & $2 \mathrm{~mm}$ & $20 \mathrm{~s}$ & 32,10 \\
\hline UTL & $2 \mathrm{~mm}$ & $20 \mathrm{~s}$ & 32,60 \\
\hline UTL & $1 \mathrm{~mm}$ & $40 s$ & 45,00 \\
\hline UTL & $1 \mathrm{~mm}$ & $40 s$ & 40,40 \\
\hline UTL & $1 \mathrm{~mm}$ & $40 \mathrm{~s}$ & 50,70 \\
\hline UTL & $1 \mathrm{~mm}$ & $40 s$ & 42,90 \\
\hline UTL & $1 \mathrm{~mm}$ & $40 s$ & 50,90 \\
\hline UTL & $2 \mathrm{~mm}$ & $40 s$ & 40,10 \\
\hline UTL & $2 \mathrm{~mm}$ & $40 \mathrm{~s}$ & 42,40 \\
\hline UTL & $2 \mathrm{~mm}$ & $40 s$ & \\
\hline UTL & $2 \mathrm{~mm}$ & $40 \mathrm{~s}$ & 42,00 \\
\hline UTL & $2 \mathrm{~mm}$ & $40 s$ & 40,40 \\
\hline UTL & $1 \mathrm{~mm}$ & $60 \mathrm{~s}$ & 59,02 \\
\hline UTL & $1 \mathrm{~mm}$ & $60 s$ & 48,62 \\
\hline UTL & $1 \mathrm{~mm}$ & $60 s$ & 49,86 \\
\hline
\end{tabular}




\begin{tabular}{|c|c|c|c|}
\hline UTL & $1 \mathrm{~mm}$ & $60 \mathrm{~s}$ & 58,30 \\
\hline UTL & $1 \mathrm{~mm}$ & $60 \mathrm{~s}$ & 59,50 \\
\hline UTL & $2 \mathrm{~mm}$ & $60 \mathrm{~s}$ & 49,20 \\
\hline UTL & $2 \mathrm{~mm}$ & $60 \mathrm{~s}$ & 36,90 \\
\hline UTL & $2 \mathrm{~mm}$ & $60 \mathrm{~s}$ & 39,40 \\
\hline UTL & $2 \mathrm{~mm}$ & $60 \mathrm{~s}$ & 47,20 \\
\hline UTL & $2 \mathrm{~mm}$ & $60 \mathrm{~s}$ & 50,10 \\
\hline UB3 & $1 \mathrm{~mm}$ & $20 \mathrm{~s}$ & 51,82 \\
\hline UB3 & $1 \mathrm{~mm}$ & $20 \mathrm{~s}$ & 55,06 \\
\hline UB3 & $1 \mathrm{~mm}$ & $20 \mathrm{~s}$ & 56,98 \\
\hline UB3 & $1 \mathrm{~mm}$ & $20 \mathrm{~s}$ & 53,66 \\
\hline UB3 & $1 \mathrm{~mm}$ & $20 \mathrm{~s}$ & 59,32 \\
\hline UB3 & $2 \mathrm{~mm}$ & $20 \mathrm{~s}$ & 38,32 \\
\hline UB3 & $2 \mathrm{~mm}$ & $20 \mathrm{~s}$ & 44,86 \\
\hline UB3 & $2 \mathrm{~mm}$ & $20 \mathrm{~s}$ & 53,00 \\
\hline UB3 & $2 \mathrm{~mm}$ & $20 \mathrm{~s}$ & 46,98 \\
\hline UB3 & $2 \mathrm{~mm}$ & $20 s$ & 50,82 \\
\hline UB3 & $1 \mathrm{~mm}$ & $40 s$ & 57,32 \\
\hline UB3 & $1 \mathrm{~mm}$ & $40 \mathrm{~s}$ & 48,00 \\
\hline UB3 & $1 \mathrm{~mm}$ & $40 s$ & 58,68 \\
\hline UB3 & $1 \mathrm{~mm}$ & $40 s$ & 51,82 \\
\hline UB3 & $1 \mathrm{~mm}$ & $40 \mathrm{~s}$ & 54,48 \\
\hline UB3 & $2 \mathrm{~mm}$ & $40 s$ & 50,20 \\
\hline UB3 & $2 \mathrm{~mm}$ & $40 \mathrm{~s}$ & 48,66 \\
\hline UB3 & $2 \mathrm{~mm}$ & $40 \mathrm{~s}$ & 55,92 \\
\hline UB3 & $2 \mathrm{~mm}$ & $40 s$ & 52,34 \\
\hline UB3 & $2 \mathrm{~mm}$ & $40 \mathrm{~s}$ & 45,36 \\
\hline UB3 & $1 \mathrm{~mm}$ & $60 \mathrm{~s}$ & 55,30 \\
\hline
\end{tabular}




\begin{tabular}{|c|c|c|c|}
\hline UB3 & $1 \mathrm{~mm}$ & $60 s$ & 53,18 \\
\hline UB3 & $1 \mathrm{~mm}$ & $60 s$ & 54,12 \\
\hline UB3 & $1 \mathrm{~mm}$ & $60 s$ & 61,24 \\
\hline UB3 & $1 \mathrm{~mm}$ & $60 s$ & 62,96 \\
\hline UB3 & $2 \mathrm{~mm}$ & $60 \mathrm{~s}$ & 52,76 \\
\hline UB3 & $2 \mathrm{~mm}$ & $60 \mathrm{~s}$ & 54,98 \\
\hline UB3 & $2 \mathrm{~mm}$ & $60 s$ & 47,06 \\
\hline UB3 & $2 \mathrm{~mm}$ & $60 s$ & 47,06 \\
\hline UB3 & $2 \mathrm{~mm}$ & $60 \mathrm{~s}$ & 55,74 \\
\hline UB6 & $1 \mathrm{~mm}$ & $20 \mathrm{~s}$ & 45,96 \\
\hline UB6 & $1 \mathrm{~mm}$ & $20 \mathrm{~s}$ & 46,20 \\
\hline UB6 & $1 \mathrm{~mm}$ & $20 \mathrm{~s}$ & 45,58 \\
\hline UB6 & $1 \mathrm{~mm}$ & $20 \mathrm{~s}$ & 45,54 \\
\hline UB6 & $1 \mathrm{~mm}$ & $20 s$ & 42,84 \\
\hline UB6 & $2 \mathrm{~mm}$ & $20 \mathrm{~s}$ & 40,12 \\
\hline UB6 & $2 \mathrm{~mm}$ & $20 \mathrm{~s}$ & 41,58 \\
\hline UB6 & $2 \mathrm{~mm}$ & $20 \mathrm{~s}$ & 36,84 \\
\hline UB6 & $2 \mathrm{~mm}$ & $20 \mathrm{~s}$ & 38,16 \\
\hline UB6 & $2 \mathrm{~mm}$ & $20 \mathrm{~s}$ & 46,58 \\
\hline UB6 & $1 \mathrm{~mm}$ & $40 s$ & 56,10 \\
\hline UB6 & $1 \mathrm{~mm}$ & $40 s$ & 52,46 \\
\hline UB6 & $1 \mathrm{~mm}$ & $40 s$ & 55,10 \\
\hline UB6 & $1 \mathrm{~mm}$ & $40 s$ & 54,04 \\
\hline UB6 & $1 \mathrm{~mm}$ & $40 s$ & 51,54 \\
\hline UB6 & $2 \mathrm{~mm}$ & $40 s$ & 58,62 \\
\hline UB6 & $2 \mathrm{~mm}$ & $40 \mathrm{~s}$ & 54,28 \\
\hline UB6 & $2 \mathrm{~mm}$ & $40 \mathrm{~s}$ & 59,00 \\
\hline UB6 & $2 \mathrm{~mm}$ & $40 s$ & 50,46 \\
\hline
\end{tabular}




\begin{tabular}{cccc} 
UB6 & $2 \mathrm{~mm}$ & $40 \mathrm{~s}$ & 58,26 \\
\hline UB6 & $1 \mathrm{~mm}$ & $60 \mathrm{~s}$ & 51,10 \\
UB6 & $1 \mathrm{~mm}$ & $60 \mathrm{~s}$ & 52,48 \\
UB6 & $1 \mathrm{~mm}$ & $60 \mathrm{~s}$ & 49,66 \\
UB6 & $1 \mathrm{~mm}$ & $60 \mathrm{~s}$ & 57,62 \\
UB6 & $1 \mathrm{~mm}$ & $60 \mathrm{~s}$ & 57,44 \\
\hline UB6 & $2 \mathrm{~mm}$ & $60 \mathrm{~s}$ & 54,64 \\
UB6 & $2 \mathrm{~mm}$ & $60 \mathrm{~s}$ & 50,54 \\
UB6 & $2 \mathrm{~mm}$ & $60 \mathrm{~s}$ & 52,88 \\
UB6 & $2 \mathrm{~mm}$ & $60 \mathrm{~s}$ & 47,88 \\
UB6 & $2 \mathrm{~mm}$ & $60 \mathrm{~s}$ & 52,36 \\
\hline
\end{tabular}




\section{REFERÊNCIAS BIBLIOGRÁFICAS}

1 ARAUJO, R.M.; ARAUJO, M.A.M.; FERNANDES, R.V.B. Efeitos da intensidade de luz e irradiação de calor de fotopolimerizadores em função do tempo de uso. JBC - J Bras Clin Odont Integr,, v.1, n.6, p.50-5, nov./dez. 1997.

2 ASENJO-MARTINEZ, M.A.J. Avaliação do desgaste e da rugosidade superficial de uma resina composta, após a escovação simulada, em função de diferentes energias e fontes de luz usadas na polimerização. Bauru, 2004. 154p. Dissertação (Mestrado) - Faculdade de Odontologia de Bauru, Universidade de São Paulo.

3 ASMUSSEN, E.; PEUTZFELDT, A. Light-emitting diode curing: Influence on selected properties of resin composites. Quint Int, v.34, n.1, p.71-75, Jan 2003.

4 ATMADJA, G.; BRYANT, R.W. Some factors influencing the depth of cure of visible light-activated composite resins. Aust Dent J, v.35, n.3, p.213-8, June 1990

5 BALA, O.; ÖLMEZ, A.; KALAYCI, S. Effect of LED and halogen light curing on polymerization of resin-based composites. J Oral Rehab, v.32, n.2, p.134140, Feb. 2005.

6 BARGHI, N.; BERRY, T.; HATTON, C. Evaluating intensity output of curing lights in private dental offices. J Am Dent Assoc, v.22, n.7, p.97-102, July 1994.

*Normas recomendadas para uso no âmbito da Universidade de São Paulo, com base no documento "Referências Bibliográficas: exemplos", emanados do Conselho Supervisor do Sistema Integrado de Bibliotecas da USP, em reunião de 20 de setembro de 1990. 
7 BOSQUIROLI, V. Avaliação da resistência à tração de uma resina composta fotopolimerizável em função de diferentes fontes de luz e de tempos de ativação. Bauru, 2003. 107p. Dissertação (Mestrado) Faculdade de Odontologia de Bauru, Universidade de São Paulo.

8 BOTTINO, M.C. et al. Comparação da efetividade de polimerização do LED a fotoativação convencional e gradual. Rev Inst Ciênc Saúde, v.21, n.1, p.839, jan./mar. 2003.

9 BURGESS, J.O. et al. Light curing - an update. Compend Contin Educ Dent, v.23, n.10, p.889-906, Oct. 2002.

10 CALHEIROS, F.C. et al. Relação entre tensão de contração e grau de conversão em compósitos restauradores. Pesq Odont Bras, v.17, p.134, 2003. Suplemento 2./ Resumo Pa219/

11 CARVALHO, R.M. et al. A review of polymerization contraction: The influence of stress development versus stress relief. Oper Dent, v.21, n.1, p.17-24, Jan./Feb. 1996.

12 CAUGHMAN, W.F.; RUEGGERBERG, F.A.; CURTIR JUNIOR, J.W. Clinical guidelines for photocuring restorative resins. J Am Dent Assoc, v.126, n.9, p.1280-6, Sept. 1995.

13 CAUGHMAN, W.F. et al. Correlation of cytotoxicity, filler loading and curing time of dental. composites. Biomaterials, v.12, n.8, p.737-40, Oct. 1991.

14 CHRISTENSEN, G.J. The curing light dilemma. J Am Dent Assoc, v.133, n.6, p.761-3, June 2002. 
15 DAVIDSON-KABAN, S.S. et al. The effect of curing light variation on bulk curing and wall-to-wall quality of two types and various shades of resin composites. Dent Mater, v.13, p.344-52, 1997.

16 DEB, S.; SEHMI, H. A comparative study of the properties of dental resin composites polymerized with plasma and halogen light. Dent Mat, v.19, n. 6, p.517-22, Sept. 2003.

17 DUNN, W.J.; BUSH, A.C. A comparison of polymerization by light-emitting diode and halogen-based light-curing units. J Am Dent Assoc, v.133, n.3, p.335-41, Mar. 2002.

18 DUNNE, S.M.; DAVIES, B.R.; MILLAR, B.J. A survey of the effectiveness of dental light-curing units and comparison of light testing devices. Br Dent J, v.180, n.1, p.411-6, June 1996.

19 DUKE, E.S. Light-emitting diodes in composite resin photopolymerization. Compend Contin Educ Dent, v.22, n.9, p.722-5, Sept. 2001.

20 FEILZER, A. et al. Influence of light intensity on polymerization shrinkage and integrity of restoration-cavity interface. Eur J Oral Sci, v.66, n.11, p.322-6, Oct 1995.

21 FERRACANE, J.L. et al. Relationship between shade and depth of cure for light-activated dental composite resins. Dent Mat, v.2, n.2, p.80-4, Apr. 1986.

22 FERRAREZI, G.A.O.; CEFALY, D.F.G.; NAVARRO, M.F.L. Microdureza de materiais resinosos polimerizados com luz halógena e luz emitida por diodo 
(LED). Pesq Odontol Bras, v.17, p.94, 2003. Suplemento 2./ Resumo Ic118/

23 FOWLER, C.S.; SWARTZ, M.L.; MOORE, B.K. Efficacy testing of visible-lightcuring units. Oper Dent, v.19, n.2, p.47-52, Mar./Apr. 1994.

24 FRANCO, E.B.; LOPES, L.G. Conceitos atuais na polimerização de sistemas restauradores resinosos. BiOdonto, v.1, n.2, p.1-59, mar./abr. 2003.

25 FRANCO, E.B.; BOSQUIROLI, V.; LOPES, L.G. LED: uma nova tecnologia para fotopolimerização. Avaliação com cimento ionomérico modificado por resina. JBC - J Bras Clin Odont Integr, v.7, n.38, p.112-5, mar./abr. 2003.

26 FRANCO, E.B. et al. Avaliação da profundidade de polimerização e dureza de resinas compostas fotopolimerizáveis com e sem a interferência do esmalte dentário. Rev Bras Odontol, v. 48. n.1, p. 24-7, jan./fev. 1991.

27 FRANCO, E.B. et al. Evaluation of compatibility between different types of adhesive and dual-cured resin cement. J Adhes Dent, v.4, n.4, p.1-5, Winter 2002.

28 FUJIBAYASHI, K. et al. Newly developed curing unit using blue light-emitting diodes. Dent Jpn, v.34, p.49-53, Mar. 1998.

29 HALVORSON, R.H.; ERICKSON, R.L.; DAVIDSON, C.L. Energy dependent polymerization of resin-based composite. Dent Mat, v.18, n.6, p.463-9, Sept. 2002. 
30 HALVORSON, R.H.; ERICKSON, R.L.; DAVIDSON, C.L. An energy conversion relationship predictive of conversion profiles and depth of cure for resin-based composite. Oper Dent, v.28, n.3, p.307-14, May/June 2003.

31 HAMMESFAHR, P.D.; O'CONNOR, M.T.; WANG, X. Light curing technology: Past, present and future. Compend Contin Educ Dent, v.23, n.9, p.18-24, Sept. 2002. Supplement 1

32 HANSEN, E.K.; ASMUSSEN, E. Visible-light curing units: correlation between depth of cure and distance between exit window and resin surface. Acta Odontol Scand, v.55, n.3, p.162-6, June 1997.

33 HARRINGTON, E.; WILSON, H.J. Visible-light curing units: correlation between depth of cure and distance between exit window and resin surface. J Oral Rehabil, v.22, p.377-85, 1995.

34 HARRINGTON, E.; WILSON, H.J.; SHORTALL, A.C. Light-actived restorative materials: a method of determining effective radiation times. $\mathbf{J}$ Oral Rehabil,v.23, n.3, p.210-8, Mar. 1996.

35 JANDT, K.D. et al. Depth of cure and compressive strength of dental composites cured with blue light emitting diodes (LEDs). Dent Mat, v.16, n.1, p.41-7, Jan. 2000.

$36 \mathrm{KNEZEVIC}, \mathrm{A}$. et al. Degree of conversion and temperature raise during polymerization of composite resin samples with blue diodes. J Oral Rehabil, v.28, n.6, p.586-91, June 2001. 
37 KORAN, P.; KÜRSCHNER, R. Effect of sequential versus continuous irradiation of a light-cured resin composite on shrinkage, viscosity, adhesion, and degree of polymerization. Am J Dent, v.11, n.1, p.17-22, Feb. 1998.

38 KURACHI, C. et al. Hardness evaluation of dental composite polymerized with experimental LED-based devices. Dent Mat, v.17, n.4, p.309-15, July 2001.

39 LEONARD, D.L. et al. Determination of the minimum irradiance required for adequate polymerization of a hybrid and a microfill composite. Oper Dent, v.26, p.176-80, 2001.

40 LEONARD, D.L. et al. Polymerization efficiency of LED curing lights. J Esthet Restor Dent, v.14, n.5, p.286-95, Sept. 2002.

41 LOPES, L.G. Avaliação da contração de polimerização e das tensões promovidas em função de diferentes sistemas de polimerização e de materiais restauradores estéticos. Bauru, 2003, 134p. Tese (Doutorado) Faculdade de Odontologia de Bauru, Universidade de São Paulo.

42 LOVELL, L.G. et al. The effect of cure rate on the mechanical properties of dental resins. Dent Mat, v.17, n.6, p.504-11, Nov. 2001.

43 MARTIN, F.E. A survey of the efficiency of visible light curing units. J Dent, v.26, n.3, p.239-43, Mar. 1998.

44 McCABE, J.F.; CARRICK, T.E. Output from visible-light activation units and depth of cure of light-activated composites. J Dent Res, v.68, n.11, p.15349, Nov. 1989. 
45 MEDEIROS, I.S. Dispositivos LED para polimerização de resinas compostas dentais em comparação com outras fontes de luz. São Carlos, 2001, 113p. Dissertação (Mestrado) - Universidade de São Paulo/ São Carlos.

$46 \mathrm{MEHL}$, A. et al. Physical properties and gap formation of light-cured composites with and without 'softstart-polymerization'. J Dent, v.25, n.3/4, p.321-30, May/July 1997.

47 MILLAR, B.J.; NICHOLSON, J.W. Effect of curing with a plasma light on the properties of polymerizable dental restorative materials. J Oral Rehabil, v.28, n.6, p.549-52, June 2001.

48 MILLS, R.W.; JANDT, K.D.; ASHWORTH, S.H. Dental composite depth of cure with halogen and blue light emitting diode technology. Brit Dent J, v.186, n.8, p.388-91, Apr. 1999.

49 MILLS, R.W.; UHL, A.; JANDT, K.D. Optical power outputs, spectra and dental composite depths of cure, obtained with blue light emitting diode (LED) and halogen light curing units (LCUs). Br Dent J, v.193, n.8, p.459-63, Oct. 2002.

50 MIYAZAKI, M. et al. Effect of light exposure on fracture toughness and flexural strength of light-cured composites. Dent Mater, v.12, n.5, p.328-32, Nov. 1996.

51 NOMOTO, R. Effect of light wavelength on polymerization of light-cured resins. Dent Mater J, v.16, n.1, p.60-73, June 1997. 
52 NOMURA, Y. Thermal analysis of dental resins cured with blue light-emitting diodes (LEDs). J Biomed Mat Res, v.63, n.2, p.209-13, Jan. 2002.

53 PEREIRA S.K. et al. Intensidade de luz e profundidade de polimerização de aparelhos fotopolimerizadores. Rev Assoc Paul Cir Dent, v.51, n.3, p.25760, maio/jun. 1997.

54 PEREIRA, M.A.S. et al. Estudo da profundidade de polimerização de resina por alguns aparelhos fotopolimerizadores: relação com a dureza. Rev Bras Odont, v.57, n.3, p.156-60, maio/jun. 2000.

55 PEREIRA, S.K.; PORTO, C.L.A.; MENDES, A.J.D. Efeitos de diferentes sistemas de fotopolimerização na dureza superficial da resina composta. JBC - J Bras Clin Estet Odontol, v.5, n.26, p.156-161, 2001.

56 PHILLIPS, R.W. Materiais dentários de Skinner. 7ed. Interamericana, 1978.

57 PILO, R.; CARDASH, H.S. Post-irradiation polymerization of a different anterior and posterior visible light-activated resin composites. Dent Mat, v.8, n.5, p.299-304, Sept. 1992.

58 PRICE, R.B.T.; MURPHY, D.G.; DÉRAND, T. Light energy transmission through cured resin composite and human dentin. Quint Int, v.31, n.9, p.659-67, Oct. 2000.

59 PRICE, R.B.T.; FELIX, C.A.; ANDREOU, P. Evaluation of a second-generation LED curing light. J Can Dent Assoc, v.69, n.10, p.666-666h, Nov. 2003. 
60 PRICE, R.B.T.; FELIX, C.A.; ANDREOU, P. Effects of resin composite composition and irradiation distance on the performance of curing lights. Biomaterials, v.25, n.18, p.4465-77, Aug. 2004.

61 RIBEIRO, J.P.F. et al. Avaliação da microdureza Vickers de um compósito odontológico utilizando aparelho halógeno e a base de LEDs. Pesq Odontol Bras, v.17, p.185, 2003. Suplemento 2. / Resumo Pb216/

62 RUEGGEBERG, F.A. Contemporary issues in photocuring. Compendium, v.20, p.4-15, Nov. 1999. Suplemento 25

63 RUEGGEBERG, F.A.; CRAIG R.G. Correlation of parameters used to estimate monomer conversion in light-curing composite. J Dent Res, v.67, n.6, p.932-7, June 1998.

64 RUEGGEBERG, F.A.; JORDAN D.M. Effect of light tip distance on polymerization of resin composite. Int J Prosthodont, v.6, n.4, p.364-70, July/Aug. 1993.

65 RUEGGEBERG, F.A.; CAUGHMAN, W.F.; CURTIS, J.W. Effect of light intensity and exposure duration on cure of resin composite. Oper Dent, v19, n.1, p.26-32, Jan./Feb. 1994.

66 SAKAGUCHI, R.L.; BERGE, H.X. Reduced light energy density decreases post-gel contraction while maintaining degree of conversion in composites. $\mathbf{J}$ Dent, v.26, n.8, p.695-700, Nov. 1998. 
67 SANTOS, L.A. et al. Microdureza de resina composta: efeito de aparelhos e tempos de polimerização em diferentes profundidades. Pesq Odontol Bras, v.14, n.1, p.65-70, jan./fev. 2000.

68 SHORTALL, A.C.; HARRINGTON, E. Guidelines for the selection, use and maintenance of visible light activation units. Brit Dent J, v.181, n.10, p.3837, Nov. 1996.

69 SHORTALL, A.C.; HARRINGTON, E. Effectiveness of battery powered light activation units. Br Dent J, v.183, n.3, p.95-100, Aug.1997.

70 SOH, M.S.; YAP, A.U.J; SIOW, K.S. Effectiveness of composite cure associated with different curing modes of LED lights. Oper Dent, v.28, n.4, p.371-7, July/Aug. 2003.

$71 \mathrm{SOH}, \mathrm{M} . \mathrm{S}$; YAP, A.U.J. Influence of curing modes on crosslink density in polymer structures. J Dent, v.32, n.4, p.321-6, May 2004.

72 STAHL, F. et al. Light-emitting diode (LED) polymerization of dental composites: flexural properties and polymerization potential. Biomaterials, v.21, n.13, p.1379-85, July 2000 .

73 TARLE, Z.; et al. Composite conversion and temperature rise using a conventional, plasma arc, and an experimental blue LED curing unit. J Oral Rehabil, v.29, n. 7, p.662-7, July 2002.

74 TRUJILLO, M.; NEWMAN, S.M.; STANSBURY, J.W. Use of near-IR to monitor the influence of external heating on dental composite photopolymerization. Dent Mat, v.20, n.8, p.766-77, Oct. 2004. 
75 TURBINO, M.L. et al. Photopolymerized resins: surface hardness variation in relation to time of polymerization and setting. Braz Dent J, v.3, n.2, p.87-94, 1992.

76 TSAI, P.C.L.; MEYERS, I.A.; WALSH, L.J. Depth of cure and surface microhardness of composite resin cured with blue LED curing lights. Dent Mat, v.20, n.4, p.364-9, May 2004.

77 UHL, A.; MILLS, R.W.; JANDT, K.D. Polymerization and light-induced heat of dental composites cured with LED and halogen technology. Biomaterials, v.24, n.10, p.1809-20, May 2003.

78 WANG, L. et al. Mechanical properties of dental restorative materials: relative contribution of laboratory tests. J Appl Oral Sci, v.11, n.3, p.162-7, July/Sept. 2003.

79 WHITTERS, C.J.; GIRKIN, J.M.; CAREY, J.J. Curing of dental composites by use of InGaN light-emitting diodes. Optics Letters, v.24, n.1, p.67-8, 1999.

80 YAP, A.U.J.; SENEVIRATNE, C. Influence of light energy density on effectiveness of composite cure. Oper Dent, v.26, n.5, p.460-6, Sept./Oct. 2001.

81 YEARN, J.A.; MACCLESFIELD, UK. Factors affecting cure of visible light activated composites. Int Dent J, v.35, n.3, p.218-5, Sept. 1985.

82 YOON, H.H. et al. Degree of polymerization of resin composites by different light sources. J Oral Rehabil, v.29, n.12, p.1165-73, Dec. 2002. 


\section{ABStRACT}

\section{Evaluation of tensile strength and microhardness of a photo polymerizing resin composite, cured with light curing units - halogen and LED.}

The aim of this study was to evaluate the tensile strength, through tensile tests, of a photopolymerizable composite resin (Filtek Z250 - 3M/ESPE), with variation of material's thickness, using an halogen light curing unit (Curing Light $2500-3 \mathrm{M} / \mathrm{ESPE}-\mathrm{CL}$ ) and two light emitting diodes units (Ultraled - Dabi/Atlante - UL; Ultrablue IS - DMC - UB3 and UB6) with different power densities (130, 300,600 and $\left.640 \mathrm{~mW} / \mathrm{cm}^{2}\right)$, as well as the influence of activation times $(20,40$ and 60 s) and, additionally, relate this data with the Knoop microhardness in that area corresponding to the fracture region of material. A number of 24 groups were stablished and a set of stainless matrix composed by two parts was used, with thickness of 1 and $2 \mathrm{~mm}$, to obtain the specimens. Next, the specimens were submitted to tensile tests in a Universal Testing Machine (Kratos), using a crosshead speed of $0,5 \mathrm{~mm} / \mathrm{min}$ and a $50 \mathrm{Kg}$ load cell until fracture. Tensile strength values were calculated in $\mathrm{kgf} / \mathrm{cm}^{2}$ and translated into MPa. To microhardness test, the same matrix was used to obtain the specimens (24 groups $-n=5)$, analyzing the hardness in the surfaces exposed and non-exposed to the light source. The Knoop microhardness test was made using a Shimadzu HMV-2 Microhardness Tester, at a static load of $50 \mathrm{~g}$ at 30 seconds. The values obtained were submitted to three-way ANOVA and for individual comparison a Tukey test 
was applied with a 0.05 significance level. The results showed that, with regard to individual performance of light curing units studied, there was similarity in tensile strength to the different activation times evaluated (20, 40 and $60 \mathrm{~s})$, both to $1 \mathrm{~mm}$ of thickness as $2 \mathrm{~mm}$; (2) Composite resin showed superior tensile strength to $2 \mathrm{~mm}$ thickness, while with respect to microhardness at the area corresponding to union interface, the values were higher when specimens with $1 \mathrm{~mm}$ thickness were tested, demonstrating that a higher hardness does not implies superior tensile strength; (3) In relation to microhardness, halogen curing unit reached higher results than LED units; (4) The variation of thickness and exposure time didn't have an influence on union interface microhardness to the different units tested, but it was evident that units with lower power density need a longer activation time to behavior equally that light sources with high power density. 